\title{
THE CONSTITUTION'S ACCOMMODATION OF SOCIAL CHANGE $\dagger$
}

\author{
Philip A. Hamburger *
}

TABle OF CONTENTS

I. Eighteenth-Century Theories of Social AND

Legal Change ............................. 245

A. The Theories ............................ 246

B. American Awareness of Such Theories ........... 254

II. The Newer Concept of a Constitution AND the IDEA OF PERMANENCE $\ldots \ldots \ldots \ldots \ldots \ldots \ldots \ldots \ldots \ldots . \ldots \ldots$

III. Anti-Federalists on the Constitution and Social Change ................................... 265

A. The Permanency of Liberty and Republican Government............................ 265

B. The Permanent Constitution .................. 267

IV. Federalists on the Constitution and Social Change.................................. 271

A. The Permanency of Liberty and Republican

Government ............................. 272

B. The Permanent Constitution ................. 275

1. General Statements .................... 276

2. Nondiscretionary Provisions ................ 281

3. Discretionary Provisions ................. 287

4. Anti-Federalists on the Avoidance of
Obsolescence............................ 297

V. AMENDMENT ................................ 300

VI. INDETERMINACY $\ldots \ldots \ldots \ldots \ldots \ldots \ldots \ldots \ldots \ldots \ldots, 302$

A. Vagueness........................... 303

1. The Epistemological Foundations of Language ... 303

$\dagger$ (C) 1989 by Philip A. Hamburger

* Professor of Law, University of Connecticut. B.A. 1979, Princeton University; J.D. 1982, Yale Law School. - Ed. It is a pleasure to acknowledge my indebtedness to the following persons for their exceedingly helpful comments and advice: M.M. Arkin, W. Berns, D.A. Calloway, S.A. Conrad, V. Gourevitch, S.N. Katz, R.S. Kay, J. Lindgren, H.C. Macgill, T.H. Morawetz, W.E. Nelson, K. Newmeyer, D.R. Ortiz, S.G. Utz, and C.A. Weisbrod. I am also grateful for having had the opportunity to discuss earlier drafts in the University of Connecticut Law School Faculty Colloquium and in the New York University Law School Legal History Colloquium. I wish to thank the John M. Olin Foundation, Inc., for its generous grant in support of a summer research fellowship. 
2. Vagueness and Interpretation .............. 306

3. Vagueness and Rights .................. 313

B. Principles............................. 317

C. General Language ........................ 319

D. The Compatibility of Precision with Principles and General Language .......................... 321

ConClusion ................................. 325

Did the framers and ratifiers of the United States Constitution think that changes in American society would require changes in the text or interpretation of the Constitution? ${ }^{1}$ If those who created the Constitution understood or even anticipated the possibility of major social alterations, how did they expect constitutional law - text and interpretation - to accommodate such developments?

The effect of social change upon constitutional law was an issue the framers and ratifiers frequently discussed. For example, when AntiFederalists complained of the Constitution's failure to protect the jury trial in civil cases, Federalists responded that a change of circumstances might, in some instances, render the current form of jury trial inappropriate and obsolete. Hamilton wrote that

the changes which are continually happening in the affairs of society may render a different mode of determining questions of property preferable in many cases in which that mode of trial now prevails. . . The examples of innovations which contract its ancient limits, as well in these States as in Great Britain, afford a strong presumption that its former extent has been found inconvenient, and give room to suppose that future experience may discover the propriety and utility of other excep-

1. In this article, the following abbreviated references are used: DocumENTARY History refers to THE Documentary History OF THE RATIFICATION OF THE CONSTITUTION OF THE United States (M. Jensen, J. Kaminski \& G. Saladino eds. 1976-89); J. Elliot refers to The Debates in the Several State Conventions on the Adoption of the Federal ConSTITUTion (J. Elliot ed. 1941); M. FARRAND refers to The Records of THE Federal ConVENTION OF 1787 (M. Farrand \& J. Hutson eds. 1966 \& Supp. 1987); FIRST FEDERAL Elections refers to The Documentary History of the First Federal Elections, 17881790 (M. Jensen, R. Becker \& G. DenBoer eds. 1976-86); P. Ford, EsSAYS refers to EsSAYS ON the Constitution of the United States (P. Ford ed. 1982); P. Ford, Pamphlets refers to Pamphlets on the Constitution of the United States (P. Ford ed. 1968); B. Schwartz, Bill of Rights refers to The Bill of Rights: A Documentary History (B. Schwartz ed. 1971); H. Storing refers to The Complete Anti-Federalist (H. Storing ed. 1981).

A few words about terminology are necessary. In this article, "debates" refers to written as well as oral debates, unless otherwise indicated. The meaning attributed to "social change" is discussed in the text at notes 10-11 infra. Unless otherwise indicated, the terms "Federalist" and "Anti-Federalist" are used here to refer not only to ratifiers but also to framers of the Constitution who held views similar to the opinions expressed by Federalists and Anti-Federalists during ratification. Such usage is convenient in this article, because most framers appear to have held opinions on the issues examined here not unlike the opinions of later Federalists. Of course, such usage may be inappropriate for other purposes, and even in this article is subject to the qualification that framers and ratifiers were arguing in very different contexts. 
tions. I suspect it to be impossible in the nature of the thing to fix the salutary point at which the operation of the institution ought to stop, and this is with me a strong argument for leaving the matter to the discretion of the legislature. ${ }^{2}$

According to Hamilton, a right to a jury in civil cases would become obsolete and therefore should be left to the legislature rather than be fixed in the Constitution.

A similar dispute took place in the Virginia ratification convention on the subject of the common law. Patrick Henry broadly complained that the Constitution "ought to have declared the common law in force." 3 In response, Edmund Randolph argued that common law and constitutional law had to be kept distinct:

[T] he common law ought not to be immutably fixed.... It is established only by an act of the legislature, and can therefore be changed as circumstances may require it. ... The immutable establishment of the common law would have been repugnant to that regulation. It would, in many respects, be destructive to republican principles, and productive of great inconveniences. . . . the writ of burning heretics would have been revived .... It may be established by an act of legislature. Its defective parts may be altered, and it may be changed and modified as the convenience of the public may require it. ${ }^{4}$

The Constitution contained what was "immutably fixed," whereas the common law was a repository for laws that would have to be "changed as circumstances may require it."

These statements reveal some understanding of the idea that law must change with the development of society, but they also suggest a distinction between constitutional law, which was rigid or permanent, and other, flexible law. Almost all of the framers and ratifiers assumed that constitutions should, by their nature, be permanent. ${ }^{5}$ Federalists and Anti-Federalists differed, however, on what could be permanent. Anti-Federalists typically advocated a constitution that would inflexibly establish the essentials of liberty and republican government,

2. The Federalist No. 83, at 573 (Hamilton) (J. Cooke ed. 1961). 447.

3. Henry in Virginia Ratification Convention, June 14, 1788, in 3 J. Elliot, supra note 1, at

4. Randolph in Virginia Ratification Convention, June 14, 1788, in 3 J. ElLıoT, supra note 1, at 469-70. George Nicholas also replied to Henry: "What would have been the consequence if it had [been declared in force]? It would be immutable. But now it can be changed or modified as the legislative body may find necessary for the community." Nicholas in Virginia Ratification Convention, June 14, 1788, in id. at 451; see also Letter from James Madison to George Washington, Oct. 18, 1787, in 3 M. FarRand, supra note 1, at 129-30.

5. Statements here and later in this article to the effect that framers and ratifiers thought the Constitution "should" be permanent and fundamental are made with the understanding that constitutions were often considered to be, by definition, permanent. Most past constitutions, however, had not been permanent, and the framers and ratifiers appear to have understood that their choices could determine whether or not the U.S. Constitution would in fact have longevity. 
notwithstanding the probability of social development. This was a probability of which they were well aware, but they saw a permanent constitution as an obstacle to undesirable social change and to the loss of liberty that would accompany such change. Federalists (including most framers) ${ }^{6}$ also assumed constitutions should contain what is permanent but perceived that quality in fewer provisions than did AntiFederalists. According to Federalists, any law that would have to change according to circumstances could not be permanent. Such law, moreover, could not conveniently be flexible unless subject to legislative modification. On the basis of these arguments, Federalists insisted on excluding from the Constitution all potentially obsolete proposals - including many provisions Anti-Federalists considered essential. Thus, what Anti-Federalists thought should be permanently established by the Constitution, Federalists often decried as impermanent and appropriate only for legislative discretion. Nevertheless, Federalists and Anti-Federalists held some beliefs in common. Although they disagreed about what was permanent and essential, they shared an assumption that constitutions and, more generally, constitutional law should be permanent, that is, both inflexible and lasting.

Of course, not all framers and ratifiers conformed exactly to the opinions outlined above. For example, a relatively small number of Federalists and Anti-Federalists held these views but also acknowledged that the Constitution might have to be adapted, by amendments, to alterations in society. In general, however - notwithstanding their different perceptions of social change and permanency - neither Federalists nor Anti-Federalists thought it appropriate for constitutional law to change in adaptation to social developments.

The general historical question pursued here can be related to the twentieth-century controversy about constitutional interpretation and the nature of constitutional law. ${ }^{7}$ Commentators have frequently assumed that constitutional law inevitably changes or at least should

6. See supra note 1 .

7. Although possibly relevant to problems of interpretation, this article is not an investigation of the framers' and ratifiers' opinions about interpretation. A more fundamental question will be pursued here. The ideas of the framers and ratifiers will be discussed in order to elucidate their expectations of social change and their beliefs about how the Constitution might survive such change. Interpretation will be discussed only to the limited extent necessary to answer this broader question about social change.

H. J. Powell argues that the framers did not think their own "personal intentions" were "a definitive or even particularly valuable guide to constitutional construction." Powell, The Original Understanding of Original Intent, 98 HARV. L. REV. 885, 944 (1985). This article does not directly conflict with Powell's conclusions, for this article does not enquire as to the particular mode of interpretation desired or expected by the framers and ratifiers. On the other hand, to the extent Powell suggests the framers or ratifiers wanted constitutional law to be flexible or indeterminate, this article dissents. 
change with developments in American society - a position traditionally espoused under the rubric of a "living constitution." 8 From this point of view, both new applications of the Constitution and changes in the nature of our society may require alterations in the rules and generalizations that comprise much of our constitutional law. As America has developed, so too, it is said, has our understanding of due process and other constitutional categories. This assumption - that constitutional law must change with society - is closely related to another assumption, that constitutional texts and the law interpreted from them are, in their nature, relatively indeterminate. To meet changing circumstances (without frequent resort to the amendment process), constitutional law allegedly must be flexible; and for constitutional law to be flexible, the Constitution must, in one way or another, be indeterminate. ${ }^{9}$ This article will explore whether the framers and ratifiers had a similar understanding of constitutional law.

Another context for the issue examined here is the debate among historians about the relationship of law to society. That law, including constitutional law, reflects the society it serves is one of the truisms of modern historiography. The way, however, in which law reflects its environment is much debated. A study of how the framers and ratifiers thought the Constitution could accommodate changes in society will hardly contribute to a resolution of that controversy, but it may illuminate the history of the debate.

Incidentally, in elucidating the relationship between society and law, historians have made many different assumptions about "social change" and how it should be defined. This article concerns the framers' and ratifiers' anticipation of what they occasionally called changing "circumstances" or "exigencies" - in other words, a wide variety of developments, including some not conventionally designated "social change." For lack of a better label, ${ }^{10}$ however, that phrase will here be

8. Some commentators attribute such an understanding of the Constitution to the framers and ratifiers. Others, in contrast, insist that the Constitution was framed for the circumstances of the late eighteenth century rather than later periods and that, therefore, it has been especially in need of adaptation. The historical assumptions of these commentators will be questioned by this article.

9. A wide variety of interpretive devices can provide some flexibility in interpretation, and all or almost all of them are based to some degree on the existence or creation of indeterminacy. For example, judges may find or create textual ambiguities; they may conclude that the Constitution embodies principles or general language as authoritative as the text; they may reach similar conclusions about the purposes of provisions (purposes broader than what the framers and ratifiers aimed to accomplish); they may determine that the Constitution requires them to apply the "concept" of due process (to take one example) rather than any particular "conception" of due process; they even may ask how the framers and ratifiers, if alive today, would have dealt with a particular modern circumstance.

10. This article uses "social change" rather than the framers' and ratifiers' "changing cir- 
used to refer to the many types of change the framers and ratifiers considered when creating the Constitution. As a result, this article will treat as "social change" developments that could be more narrowly categorized as economic, political, cultural, or moral. Not only changes that alter the fundamental nature of society but also less substantial alterations and events may be within this broad understanding. Although so expansive a view of "social change" will give little comfort to those accustomed to a more conventional definition, it will at least prevent an artificial exclusion of subjects the framers and ratifiers thought relevant. ${ }^{11}$

A caveat: The inquiry pursued here concentrates on the views of the framers and ratifiers while they were creating the Constitution rather than the development of their ideas before or after that task, and this focus greatly affects the evidence that will be used. Fortunately, the record of oral and written debates about the Constitution is extensive. As a result, it is possible to rely largely upon the statements of the framers and ratifiers themselves. ${ }^{12}$ Other contemporary expressions of opinion are cited to indicate the thoughts to which the framers and ratifiers were exposed and may have been sympathetic. ${ }^{13}$ Although often highly polemical, the arguments of the framers, ratifiers, and their contemporaries can reveal much about their assumptions. ${ }^{14}$ Some conceivably relevant evidence, however, will not be

cumstances," because "social change" seems more concrete and because it focuses on framers" and ratifiers' concern about what are often considered sociologically significant developments.

11. It should also be noted that although many of the framers and ratifiers of the Constitution were very prescient, this article does not attempt to determine whether they were accurate prognosticators. Their acuity will on occasion be pointed out but only to show that they understood the potential for change in American society.

12. An assessment of the incompleteness and corruption of the record of debates at the framing and ratifying conventions may be found in Hutson, The Creation of the Constitution: The Integrity of the Documentary Record, 65 TEXAS L. REV. 1 (1986). Hutson points out that these records often abbreviated or modified what was said. Yet even debates that were not completely recorded or were rewritten for polemical purposes can reveal much about the assumptions of those arguing and those they sought to persuade. Although the debates have lost more than just their bulk as a result of the reporting and editing, the historian of ideas can place some confidence in them, if he (or she) seeks patterns of opinion, and if, when dealing with seriously corrupted records, he does not rest too much of his argument on a single word or phrase in a single speech.

13. Expressions of opinion, however, especially Anti-Federalist opinion, may have been more moderate in the framing and ratifying conventions than out of doors. The constraints of polite behavior that usually prevailed in the conventions had less effect on the written debate, especially when that debate was anonymous. The conventions brought together relatively small groups of men, many of whom were known to one another either personally or by reputation. Animosities often had to be subordinated to the various requirements of courtesy, gentlemanly behavior, republican egalitarianism, social deference, and a natural deference to reputed and conspicuously displayed ability.

14. The necessities of persuasion - particularly the adoption of opponents' assumptions for rhetorical reasons - may have contributed to the appearance of overlapping opinions. The overlap, however, was not merely rhetorical. Indeed, the polemical approach of many on each side 
relied upon. In particular, subsequent expressions of opinion (even if only slightly later) and retrospective accounts of opinions allegedly held during the making of the Constitution may be misleading sources of evidence. Opinions expressed after ratification may have been different from views held during that contest. Moreover, recollections of views held earlier may have been the product of hindsight. In light of the plethora of contemporary evidence, the possibility of changes in opinion, and the difficulty of assessing the effect of hindsight, it seems unnecessary and unwise to depend on later and riskier sources. ${ }^{15}$ In its examination of the Bill of Rights, this article makes similar distinctions about the relevant evidence. ${ }^{16}$

\section{Eighteenth-Century Theories of Social AND Legal Change}

Before discussing the framers' and ratifiers' views on how the Constitution could accommodate changes in society, it is useful to examine the intellectual context of their beliefs. Citing Kuhn's view of paradigms and Pocock's notion of ideology, Banning has written:

No man's thought is altogether free. Men are born into an intellectual universe where some ideas are native and others are difficult to conceive. Sometimes this intellectual universe is so well structured and has so

may have created the appearance of greater disagreement on general political assumptions than actually existed.

15. Occasionally, however, they will be mentioned for purposes of context or comparison.

16. It is understood that there are dangers in attempting to identify the views of any group of persons such as the framers and ratifiers. Even within smaller groups, individuals frequently do not share opinions beyond the most superficial levels of understanding. This article requires particular caution, because it seeks the framers' and ratifiers' views on an issue that some of them addressed only indirectly or in a now outmoded vocabulary.

On some issues, evidence survives concerning the opinions of only a few persons, not infrequently the most voluble, the most perspicacious, and the most articulate proponents of their point of view. In the case of Madison, Hamilton, and Wilson, for example, it is apparent that their fellow Federalists did not always entirely agree with them. More commonly, the record is silent as to whether other Federalists understood or concurred. The role of Madison, Hamilton, and Wilson as leaders in the spoken and written debates suggests that their views found considerable support.

What the framers and ratifiers thought and what they were capable of saying were, of course, very different. For example, Madison stated his analysis of factions with a sophistication and penetration peculiar to him. Some Federalists who heard or read Madison's opinions probably felt that they concurred, yet it is utterly improbable that they all could fully understand or describe the point of view themselves without greatly simplifying and thereby modifying it. Thus in the ratification debates, some Federalists expressed opinions similar but not identical to Madison's. Even if derivative, their statements were slightly different. Did they disagree with Madison on the question of factions? They probably thought not.

The varying capabilities of the framers and ratifiers were not the only causes of differences between what was thought and what was said. The framers and ratifiers could be less than candid, and some were quite skillful in this respect. Like all more-or-less public debates, the debate on the Constitution does not always directly reveal the beliefs of the participants. This is not, however, a reason for abandoning an inquiry about those opinions. It merely suggests a need for caution. 
strong a hold that it can virtually determine not only the ways in which a society will express its hopes and discontents but also the central problems with which it will be concerned. In 1789 Americans lived in such a world. The heritage of classical republicanism and English opposition thought, shaped and hardened in the furnace of a great Revolution, left few men free. This universe contained no familiar ways of thinking about gradual constitutional improvement . . . ${ }^{17}$

As will be seen, however, a variety of theories of society or law were familiar to many Americans, and these theories assumed at least two approaches to the possibility of change. Some acknowledged social and legal change; some suggested law to be relatively static. Consequently, when developing their ideas on the Constitution's accommodation of social change, Americans could choose among, and draw upon, potentially conflicting intellectual traditions. ${ }^{18}$

\section{A. The Theories}

One of the oldest theories on the relationship between legal and social change involved natural law - rules of morality that men were thought to ascertain through the use of "right reason." Of course, many natural law writers acknowledged the need for variation in human laws. Such was the position of Thomas Aquinas. ${ }^{19}$ Similarly, another great apologist of another church, Richard Hooker, employed natural law to justify Anglican deviations from the practices of the early church fathers, and he was, therefore, especially attentive to differences in obligations over time. ${ }^{20}$ More frequently, however, particularly in connection with constitutional issues, a very different emphasis was apparent. To the extent natural and positive law not only reflected moral precepts but also more directly embodied them,

17. Banning, Republican Ideology and the Triumph of the Constitution, 1789 to $1793,31 \mathrm{WM}$. \& MARY Q. 167, 178-79 (1974). In contrast, it is suggested here that at least a substantial portion of educated Americans had a mixed intellectual inheritance and therefore were not unfree in the sense suggested by Banning. For a broad reexamination of the study of ideologies, see $R$. LERNER, The Constitution and the Thinking Revolutionary, in BEYOND CONFEDERATION 38 (R. Beeman, S. Botein \& E. Carter II eds. 1987).

18. An elegant contribution to the literature on social and legal change is P. STEIN, LEGAL Evolution (1980). For a recent examination of eighteenth-century theories of social change in an American context, see D. McCoy, The Elusive Republic (1980). There is also an extensive literature on the history of the idea of progress. See, e.g., J. Bury, The IDEA of Progress (1920); S. Pollard, The Idea of Progress (1968).

19. E. Lewis, Medieval Political Ideas 12 (1954).

20. F. Paget, an Introduction to the Fifth Book of Hooker's Treatise of the Laws of Ecclesiastical Polity 101-03 (1899). Natural law was permanent and binding, but positive laws could, thought Hooker, be either permanent or mutable, according to their subjects and circumstances. R. Hooker, Of the Laws of Ecclesiastical Polity, in THE Works 272-73, 388 (I.xv.1 \& III.x.5) (1888). See also natural law discussions of desuetude and the duration of laws, e.g., Burlamaqui, Principles of Natural and Politic Laws, I.x.14. 
they were, apparently, immutable, and law that was immutable might bind even kings.

These strong suggestions of permanence were to a degree undermined by a new development in the discussion of "natural law": the analysis that continued to address natural law but explicitly posited a state of nature in which that law was supposed to be binding. ${ }^{21}$ The sovereign to which individuals in a state of nature surrendered their natural liberty, whether a monarch or the people, could choose to alter the law as it saw fit. The attempts of some theorists to describe contractual limits on government did not diminish the possibility of change. In America, where notions of contractual limits and popular sovereignty were well-received (and frequently combined), ${ }^{22}$ it was said that the people had a right to alter their constitution "at any time, for any cause, or for no cause, but their own sovereign pleasure."23 Without implying that law would necessarily be mutable, such ideas could call into question any assumptions that constitutional law should be unchanging.

Nevertheless, natural law theories continued to nurture expectations of unchanging constitutional law. Contractual limitations on government were often described as "fundamental law" - a phrase long associated with immutable limitations. Moreover, just as many Americans thought that all positive law should reflect the moral precepts of natural law, so too some hoped that constitutional law would be drafted on the basis of the unchanging principles of human nature and politics that increasingly were becoming known. ${ }^{24}$ Indeed, improved knowledge of human nature would permit the drafters of constitutions to identify the limitations fundamental or essential to the preservation of liberty, and what was fundamental to liberty did not seem to be something that should change.

Another highly influential approach to the development of law and society rested on ideas about the antiquity of the common law and the

21. Often, this later theory is said to concern the "law of nature," as distinguished from the earlier "natural law" theory. Seventeenth- and eighteenth-century writers, however, did not always use these labels in this way.

22. Americans could find these ideas already combined in Vattel's writing. J. Gough, THE Social Contract 161 (2d ed. 1957).

23. B. Hichborn, Oration Delivered At Boston (March 5, 1777), in PRINCIPLES AND ACTS OF THE REvolution in AMERICA 22 (H. Niles ed. 1822).

24. According to John Adams, the "heavenly bodies . . . do not appear to be governed by laws more uniform or certain than those that regulate the moral and political world." John Adams on the Constitution, N.Y. Journal (Feb. 23, 1788), in 16 DOCUMENTARY HISTORY, supra note 1, at 193; see also D. Boorstin, The Mysterious ScIENCE OF LAW ch. I (1967); Hoeflich, Law and Geometry: Legal Science from Leibniz to Langdell, 30 AM. J. LEGAL. HIST. 95 (1980); Shapiro, Law and Science in Seventeenth Century England, 21 STAN. L. REv. 727 (1969). 
English constitution. ${ }^{25}$ Common lawyers, arguing and writing chiefly in the seventeenth century, developed a theory that the common law, the English constitution, and particularly the House of Commons, were of ancient origin and had existed since the earliest mists of antiquity. Historically, this claim was false. Politically, it had immense appeal, for it supported assertions on behalf of the common law and soon also Parliamentary sovereignty and Englishmen's rights. Consequently, the assertion that there was an ancient constitution played a crucial role in seventeenth- and eighteenth-century political debates on both sides of the Atlantic. What is striking for purposes of this inquiry was not only its insistence that the institutions of the common law and the English constitution had existed from time immemorial but also its implication that the basic structure of English society was unchanging.

The common law, however, gave rise to more than one perspective on legal change. Although ancient, the common law was customary and therefore potentially flexible, and on this basis, some seventeenthcentury English historians developed a new understanding of the relationship between law and society. ${ }^{26}$ Among these historians were Selden and Spelman, whose early explorations of feudal law suggested that the legal system had undergone great changes. The physician and tory polemicist, Robert Brady, took their work to its logical conclusion. Troubled by both the historical inaccuracies and the political consequences of the ancient-constitution theory, Brady investigated the antiquity of the common law and Parliament. In so doing, he discovered the distinctive nature of feudalism and feudal law. He established that the structure of English society, landholding, and government had been fundamentally different in feudal times from what they were in the late seventeenth century, and that in the feudal period the common law and the English constitution had been correspondingly different. As Pocock has shown, Brady thus suggested that law and society can change and that they changed together. Indeed, Brady seems to have implied that modifications in the law were caused by social developments. ${ }^{27}$

Although, for political reasons, Brady's approach was hardly pop-

25. For the information in this and the next paragraph, I have relied upon J. Pocock, THE Ancient Constitution and the Feudal Law (1987) [hereinafter J. Pocock, Feudal LAw].

26. Of course, this perspective was "new" only within the limited context of seventeenth- and eighteenth-century British legal thought. For earlier views of legal change, also prompted by acquaintance with feudal law, see Kelley, Clio and the Lawyers: Forms of Historical Consciousness in Medieval Jurisprudence, 5 Medievalia et Humanistica (n.s.) 25 (1974). See also E. Kantorowicz, The King's Two Bodies: A Study in Mediaeval Political Theology 273-84 (1957); text accompanying supra note 20.

27. J. Pocock, Feudal LAw, supra note 25, at 197-98, 208-09. 
ular, a related analysis became an important element of English political thought, largely through the writing of Matthew Hale and, much later, Edmund Burke. In his influential history of the common law, Hale used metaphors to concede the unchanging nature of the common law and yet simultaneously assert its mutability:

[W]e may with just Reason say, They are the same English Laws now, that they were 600 Years since in the general. As the Argonauts Ship was the same when it returned home, as it was when it went out, tho' in that long Voyage it had successive Amendments, and scarce came back with any of its former Materials. . . .28

With this image, Hale acknowledged the antiquity and legitimacy of the seventeenth-century constitution. Having done this, he could safely and more accurately discuss changes in the law and their relation to developments in society:

Laws, the further they go from their original Institution, grow the larger, and the more numerous: In the first Coalition of a People, their Prospect is not great, they provide Laws for their present Exigence and Convenience: But in Process of Time, possibly their first Laws are changed, altered or antiquated, as some of the Laws of the Twelve Tables among the Romans were: But whatsoever be done touching their Old Laws, there must of Necessity be a Provision of New, and other Laws and Emergencies, that in a long Tract of Time will offer themselves. ${ }^{29}$

Hale's account of common law contributed to a tradition that eschewed the two extremes of static law and law subject to dramatic or revolutionary change. ${ }^{30}$ Hale thus contributed to a later perception of common law as the embodiment of what was best in English political culture - an acceptance and even veneration of inherited institutions combined with a slow, careful, and almost imperceptible adaptation of those institutions to the changing exigencies of society. ${ }^{31}$ From this perspective, the English constitution was successful because it could incrementally keep pace with the development of society yet could also maintain the appearance of unchanged antiquity, which was essential to its legitimacy.

Already, it should be apparent that two rather different under-

28. M. Hale, The History of The Common Law of England 40 (C. Grey ed. 1971) (originally published in 1713); see also id. at xxi-xxiii.

29. Id. at 41.

30. Hale was well aware of this dichotomy. See Hale, Considerations Touching the Alteration or Amendment of Lawes, in 1 F. Hargrave, A Collection of Tracts 249 (1787).

31. This tradition is usually associated with its most eloquent proponent, Edmund Burke. Hale's contribution has been discussed by J. Pocock, Burke and the Ancient Constitution: $A$ Problem in the History of Ideas, in Politics, LANguage AND Time 216-24 (1971). Burke may have drawn some of his ideas from the Scottish theorists and historians as well as from Hale. Note that Burke's appreciation of common law traditions was connected to his concern about the effect of abstract political principles - a concern that has striking parallels in the sixth edition of Adam Smith's Theory of Moral Sentiments, published in same year, 1790, as Burke's Reflections. 
standings of legal and social change could be drawn from the available theories. One understanding acknowledged the mutability of law including constitutional law - in conformity with changes in society. The other emphasized what was immutable, especially in constitutional law. Americans, it will be seen, increasingly employed both forms of analysis, recognizing the adaptive nature of most law but believing constitutional law was permanent.

Before closing this account of theories on social and legal change, it is necessary to examine some largely nonlegal theories, the oldest of which was apparent in the rudimentary account of social development associated with Aristotle and Polybius. These writers and others derivative of them recognized the phenomenon of political decay and described how democracy, aristocracy, and monarchy could degenerate into, respectively, anarchy, oligarchy, and tyranny. Each of the various types of government constituted a stage in an almost inevitable cycle of degeneration. Aristotle and Polybius deplored such changes and became influential as advocates of the mixed government, in which the characteristics of each of the other types of government harmonized or perhaps balanced each other. ${ }^{32}$ Although these were theories of government, they implied and eventually came to be understood as social theories too. For example, Montesquieu argued that each type of government could survive a different degree of luxury, sophistication, and individual selfishness, a democracy or republic requiring the greatest frugality and self-sacrifice from its citizens. ${ }^{33}$ Further, it was a simple and logical step for classical and especially seventeenth- and eighteenth-century English writers to discuss the constitutions of the one, the few, and the many in terms of social classes. Such social analysis of constitutions was well known, even platitudinous, in both England and America. ${ }^{34}$

An additional approach to society and law is apparent in the Anglo-American political thought that made use of classical ideas, especially as reinterpreted by Machiavelli - an approach that has been labelled, among other things, "civic humanism." 35 Writers in this tra-

32. According to M. Lienesch, Federalists thought "a perpetually balanced federal Constitution seemed capable of continuing forever. ... The Federal Constitution was created to apply equally to every age, never running down, wearing out, or falling into despair. As far as these Federalists writers were concerned, the new republic could continue in this state forever . ..." M. Lienesch, New Order of The Ages 135 (1988).

33. Montesquieu, The Spirit of Laws (D. Carrithers ed. 1977) (T. Nugent trans. 1750).

34. For the Polybian analysis and its reception in America, see H. Colbourn, The Lamp OF EXPERIENCE 191 (1965); B. BaIlyn, The Ideological Origins of the AMERICAN REVOlution 67-76 (1967); M. LIENESCH, supra note 32, at 68.

35. "Civic humanism" is a modern term for the republican analysis of government associated with Machiavelli, Harrington, and others. Frequently, it is referred to by the more traditional 
dition frequently sought to explain how a government could remain stable and survive. In classical and, more emphatically, civic humanist analysis, the virtue or public-spiritedness of the citizens would restrain their passions and discourage the factionalism that had undermined most governments; in reality, however, such virtue or selfrestraint seemed to be a scarce commodity. Consequently, various post-Renaissance political writers struggled to find a means of encouraging civic virtue or otherwise promoting stability. Among other things, they turned to the ancient solution of mixed government, through which the interests of the one, the few, and the many would, perhaps, balance each other.

To a considerable extent, the civic humanist writers of the seventeenth and eighteenth centuries assumed that the form of government is affected both by the mores of the citizenry and by class structure. The changing mores of the citizens were thought to lead to transformations in the forms of government. Perhaps already in classical times and certainly by the seventeenth century, the classical mixed government was believed to be grounded upon social classifications in England, the monarch, the aristocracy, and commoners. Similarly, when Harrington described the imaginary republic of Oceana, he sought to base it on the stable foundation of a large class of landowning gentry. ${ }^{36}$ When transposed in the eighteenth century from England to America, where landowning farmers were abundant, Harrington's vision lost its aristocratic character and became strikingly egalitarian. For Harrington and the many who followed him, land became a precondition for civic virtue, and changes in social structure were understood to have a profound effect upon the form of government and its stability. ${ }^{37}$

Although they recognized that social structure influenced the form of government, civic-humanist writers did not escape the vocabulary of virtue. Authors influenced by civic humanism or interested in republican government frequently thought that the permanence and sta-

and felicitous "republicanism." In this article, however, it is necessary to distinguish among the various meanings of the word "republicanism," and therefore that word is used only to mean a participatory type or nature of government. Note that persons who employed the analysis of civic humanism did not always favor or even discuss republican government.

Civic humanism has given rise to a vast literature. This essay draws upon J. Pocock, THE Machiavellian Moment (1975); J. Pocock, Civic Humanism and Its Role in Anglo-American Thought, in Politics, Language And Time, supra note 31, at 80 [hereinafter J. Pocock, Civic Humanism ]; $1 \mathrm{H}$. STORING, supra note 1 . As has recently been pointed out, civic humanism did not have as much continuity with classical thought as has sometimes been suggested, and especially in its Anglo-American form it was frequently consistent with liberalism. See T. PANGLE, THE SPIRIT OF MOdERn REPUbliCANiSM (1988).

36. J. Harrington, The Commonwealth of Oceana (1656).

37. Id. 
bility of government depended upon the nature and stability of a government's social foundations. ${ }^{38}$ In particular, political writers found a basis for the preservation of republican government in the frugal, independent, and virtuous citizen. They attributed importance to the ownership of land, largely because land could provide the independence so necessary for virtue. Consequently, rather than discuss change, many eighteenth-century Englishmen and Americans tended to refer to decline and degeneration, and rather than address questions of social change as such, they were apt to talk of a loss of virtue, a corruption of manners, or an increase in luxury.

Thus, civic humanism gave rise to a very one-sided consideration of social and legal changes and their effect on each other. It usually presented social change in the narrow and negative vocabulary of moral decay and assumed that such change inevitably led to the degeneration of government. Advocates of republican government therefore hoped to establish laws that would maintain or at least not undermine the manners and morals necessary for the preservation of republicanism. They sought to delay constitutional degeneration by staving off the decay of manners.

More than civic humanism, the work of Montesquieu reveals a direct and theoretical interest in the relationship between law and society. Montesquieu argued that laws could be efficacious only by reflecting the spirit of their society. Laws and systems of government had to vary from country to country according to a variety of factors, including climate and size of territory. Montesquieu thus argued that laws and systems of government should to some degree be determined by the nature of the society that they would affect. ${ }^{39} \mathrm{He}$ did not directly address the effect that changes in a society would have upon the laws. Yet his work clearly implied that changes in society should affect the laws, including the constitution of government. ${ }^{40}$

By far the most sophisticated concept of social and legal change was the notion of progress and the increasing refinement of society

38. In addition, the permanence of government was naturally associated with a fixed rather than a changing social structure. John Nelson has written that "[c]ommon to the founders was the assumption that economic disruption portended political unrest and social upheaval." J. Nelson, Liberty and Property xiii (1987).

39. Montesquieu, supra note 33, bk. 1, ch. 3, at 104-05.

40. From the opposite perspective, he argued that laws were capable of affecting society. Like many who were influenced by civic humanism, he was an advocate of laws that would maintain in the people those qualities that would preserve the system of government, whether a republic, aristocracy, or monarchy. For a discussion of the relationship between Montesquieu's ideas and the notion of legal change, see P. STEIN, supra note 18, at 15-19. Among the French, Fontenelle and Gouget also developed theories of social and legal change but were not as influential in the English-speaking world as Montesquieu or the Scots. 
elaborated by some Scottish moral philosophers. ${ }^{41}$ Drawing on an eclectic intellectual inheritance, including the theories outlined above, some Scots began systematically to explore how societies progress over time. The issue was not purely speculative, for educated Scots could not help but observe the backwardness of their country. They examined the development of commerce, arts and sciences, living standards, morals, and tastes. Hume's influential examination of these subjects challenged the classical and civic humanist assumption that commerce and luxury necessarily posed dangers to free governments. ${ }^{42}$ In accord with Hume's somewhat progressive view of society, Smith, Dalrymple, Ferguson, Kames, and Millar outlined versions of social development in four historical stages. ${ }^{43}$ In general, they traced human society from periods of barbarism, during which men and women subsisted by hunting and gathering, to later times of pastoral existence, then agriculture, and finally extensive commercial development. It was this commercial stage that they perceived Britain to be just then entering. ${ }^{44}$ To these Scots, the development of societies seemed progressive, and, for most, such development was largely advantageous. In this respect, the Scots departed sharply from the tradition of civic humanism, which addressed social change almost exclusively in terms of decay and degeneration. Thus, the Scots produced what are frequently considered to be the first systematic theories of progressive social change - the earliest historical sociology ${ }^{45}$

In their theories, the Scots described how human institutions, including law and government, changed and adapted over time to keep pace with the advancement of society. Hume, Dalrymple, Kames,

41. Bacon contributed much to the development of the idea of progress but is relegated to a footnote because his publications were not as directly related to social change and were not as clearly influential upon the framers and ratifiers as were the writings of the Scots. Bacon envisioned that scientific study could lead to extraordinary improvements in knowledge and material comforts. His account of a utopia, in The New Atlantis (1627), suggested the possibility of what then must have seemed fabulous changes. The book now seems astonishingly prescient.

The view of human progress that could have been perceived in accounts of the development of society from the state of nature is not discussed here, because these accounts were not historical, and, to the extent they were perceived as such, they were rendered obsolete by, among others, the Scots. For the attitudes of Hutcheson and Hume toward seventeenth-century concepts of the state of nature, see P. STEIN, supra note 18, at 11-12.

42. Robertson, The Scottish Enlightenment at the Limits of the Civic Tradition, in WEALTH AND VIRTUE 137, 157 (1983).

43. P. STEIN, supra note 18, at ch. 2. For the sources of the four-stages theory in the work of Montesquieu, Stair, and natural lawyers, see MacCormick, Law and Enlightenment, in THE ORIgins ANd Nature of The Scottish Enlightenment 160 (R. Campbell \& A. Skinner eds. 1982).

44. Ferguson doubted whether such change was an unmixed blessing. A. Ferguson, A History OF THE ORIGins OF Civil SOCIETy (1767).

45. For general accounts of the Scottish social theories, see G. BRySON, MAN AND SociETY (1945) and R. Meek, Social Science and The Ignoble Savage (1976). 
Smith, Ferguson, and Millar argued that laws and governments had first been as rudimentary as the barbaric societies they served and had gradually become more sophisticated as changes in society made such institutional improvements necessary or desirable. ${ }^{46}$ Since antiquated law could retard the development of society, legal reform was an apt means of facilitating social progress. Thus, the Scots argued that the form and nature of government would and ought to change with society's continued development. ${ }^{47}$

Of course, many of these theories addressed social change and its relationship to legal development only indirectly or for peripheral reasons. Moreover, many of the theories were at times used in conjunction or confused combination with one another. Nevertheless, they clearly presented rather varied accounts, and if Americans were aware of these theories, they could easily have perceived at least two rather different perspectives on the relationship between social change and law - including constitutional law.

\section{B. American Awareness of Such Theories}

Most of the theories that touched upon questions of social and legal change were well known in America. For some such theories, it is a commonplace that Americans were aware of them; for others, portions of the evidence must be assembled here.

That Americans knew the work of Montesquieu has long been understood and is evident from countless eighteenth-century American writings. It is now also apparent that a relatively wide range of late eighteenth-century Americans were familiar with some accounts of natural law, with the notion of the ancient constitution, and with civic humanism. ${ }^{48}$

In contrast, American awareness of the adaptability of common law is not altogether clear. Even prior to the influence of Brady and Hale, the ideas upon which they built were known. Already in 1639 ,

46. On this subject generally, see P. STEIN, supra note 18, at 23-50. For discussion of Hume, see Robertson, supra note 42, at 151-77. For Kames, see Lieberman, The Legal Needs of a Commercial Society: The Jurisprudence of Lord Kames, in WEALTH AND VIRTUE, supra note 42, at 203.

47. Although introduced by Scottish writers, these ideas soon were widely known and advocated in England.

48. For classical and civic humanist thought, see B. BAILYN, supra note 34 , and G. Wood, The Creation of the American Republic, 1776-1787 (1969). For the ancient constitution, see J. Pocock, Civic Humanism, supra note 35, at 96-99. Although there is a dispute as to how Americans made use of natural law, see infra text at note 65 , there is agreement that they studied natural law treatises. B. BAILYN, supra note 34, at 180-206; Berns, Judicial Review and the Rights and Laws of Nature, 3 SuP. CT. REV. 49, 67, 76-77 (1982). For more on their reading of natural law, see infra note 71 . 
most of the magistrates and some of the elders of Massachusetts opposed a written statement of fundamental law, on the ground that "such laws would be fittest for us, which should arise pro re nata upon occasions, etc., and so the laws of England and other states grew, and therefore the fundamental laws of England are called customs, consuetudines." 49 American familiarity with such ideas, however, was not always so well documented. Although on occasion in the eighteenth century Brady was cited, there is no evidence that he was well known. ${ }^{50}$ Hale may have been more influential, albeit chiefly among lawyers. ${ }^{51}$ In his 1790 law lectures, Wilson paraphrased Hale on legal and social change, and it is probable that other American lawyers knew Hale's work on this subject. ${ }^{52}$

The American reception of Scottish thought has been discussed by Douglas Adair, Garry Wills, and Stephen Conrad, among others, but an account more focused on the Scottish sociology must be considered. ${ }^{53}$ Having studied at Scottish universities, James Wilson's knowledge of Scottish sociology was more extensive than that of most of his

49. 1 J. WinThrop, WinTHROP'S JOURNAL "History OF NEW ENGLAND," 1630-1649, at 323-24 (J. Hosmer ed. 1908).

50. Richard Bland apparently derived some notions of constitutional change from Brady's writings. See Bland, An Inquiry into the Rights of the British Colonies, in AMERICAN PoliticaL Writing OF THE FouNDING ERA, 1760-1805, at 67, 70-72 (1983); see also From the Craftsman, in id. at 62-63. In the framing Convention, Pinckney gave an account of English constitutional history that may have reflected the views of Brady or Spelman. M. FARRAND, supra note 1, at 410 (June 25, 1787).

51. At least five libraries in colonial Virginia contained Hale's History. W. BRYSON, CENSUS of LAw Books in Colonial Virginia 53 (1978). In 1760, a leading New York lawyer, William Smith, recommended to a law student a list of reading that included Hale's History. C. Warren, A History of THE AMERICAN Bar 170 (1911). In 1782, James Kent abridged the book. Id. at 182 .

52. According to Wilson:

It is the characteristic of a system of common law that it be accommodated to the circumstances, the exigencies, and the conveniences of the people, by whom it is appointed. Now, as these circumstances, and exigencies, and conveniences insensibly change; a proportioned change, in time and in degree, must take place in the accommodated system. But though the system suffer these partial and successive alterations, yet is continues materially and substantially the same. The ship of the Argonauts became not another vessel, though almost every part of her materials had been altered during the course of her voyage.

1 Works OF J. Wilson 453-54 (J. Andrews 2d ed. 1895).

53. See Adair, "That Politics May Be Reduced to a Science": David Hume, James Madison, and the Tenth Federalist, in FAME AND THE Founding FATHERS 93 (T. Colbourn ed. 1974); G. Wills, Inventing America (1978); G. Wills, Explaining America (1981); Conrad, Polite Foundation: Citizenship and Common Sense in James Wilson's Republican Theory, 1984 SuP. CT. REv. 359. Adair and Wills have concentrated on Madison's development of Hume's ideas in Federalist Number 10; Wills has also studied the influence of the Scots (especially Hutcheson and Kames) upon Jefferson and others of the revolutionary generation; Conrad has elegantly demonstrated how Wilson made use of Reid's "common sense" philosophy. This article relies on their scholarship but focuses on one aspect of it: American knowledge of Scottish sociology. In this regard, note that $\mathrm{F}$. McDonald has recently argued that Scottish ideas on progress were influential in America. F. McDonald, Novus Ordo Seclorum: The Intellectual Origins of THE Constitution 119-23, 131-35 (1985). 
American contemporaries. He wrote a history of property and in 1790 gave a series of law lectures that were thoroughly imbued with the modern sociology and its account of legal change. On the subject of social change, Wilson believed that "[i]t is the glorious destiny of man to be always progressive. ... [A]11 may be carried to a degree of perfection hitherto unknown; perhaps, hitherto not believed." 54 Of legal change, he explained:

In the first association of a community, their prospect is not enlarged, their wants are comparatively few: but as the society increases, their views expand, and their wishes multiply: what is the consequence? New laws and provisions, suited to the growing multitude of successive exigencies, must be made. . . .

The same principle of accommodation in a system of common law, will adjust its improvement to every grade and species of improvement made by the people, in consequence of practice, commerce, observation, study, and refinement. ${ }^{55}$

Wilson continued with an account of how some laws are made obsolete by changes in society and throughout his lectures gave extensive examples of all types of social and legal change. Of course, Wilson knew more about Scottish thought than most of his American contemporaries and, conveniently for the historian, pronounced his version of it at length. Yet Wilson was not alone in his pursuit of the historical sociology.

A substantial number of the framers and ratifiers probably studied the Scottish sociology in American schools. As Adair has pointed out, nine members of the Constitutional Convention, including James Madison, attended Princeton, where the Edinburgh-trained Professor Witherspoon transmitted his version of the Scottish enlightenment, including the historical sociology. ${ }^{56}$ Not only at Princeton, according to Adair, but also "at William and Mary, at Pennsylvania, at Yale, at King's, and at Harvard, the young men who rode off to war in 1776

54. 1 WORKS OF J. WILSON, supra note 52, at 126.

55. Id. at 454 .

56. Witherspoon's surviving lectures did not directly address the question of changes in society or law. See J. Witherspoon, An Annotated Edition of Lectures on Moral PhilosOPHY (J. Scott ed. 1982). It is improbable, however, that his students would have been unaware of at least some of the Scottish sociological ideas. Witherspoon is known to have discussed Robertson's Charles $V$ and he included, among others, Hutcheson, Hume, and Ferguson in his reading list. R. Ketchum, JAmes Madison, A Biography 43-45 (1971). Goguet was also mentioned. Id. at 189-91. Of course, this is not to suggest that Witherspoon altogether approved of these authors. Note that in 1782, when Madison prepared a list of books to be purchased for a congressional library, he included Ferguson's Civil Society, Hume's Political Essays and History of England, Robertson's Charles $V$ and History of Scotland, and Smith's Wealth of Nations. 6 The Papers of JAmes Madison 65-115 (W. Hutchinson and W. Rachal eds.) (1969), cited in G. Wills, EXPlaining AmeriCA, supra note 53, at 20. 
had been trained in the texts of Scottish social science." 57 Scottish treatises "had become the standard textbooks of the colleges of the late colonial period." 58

The framers and ratifiers also had opportunities to learn about Scottish ideas on their own, for Scottish books arguing that changes in society led to changes in the law were well-represented in American libraries. A study of 121 American library and booksellers' lists dating from 1700 to 1790 (92 of which date from before 1777) reveals the following: 49 lists contained Hume's Essays; 65 had his History of England; 19 had Ferguson's Essay on the History of Civil Society; 55 showed Kames' Sketches of the History of Man; and 28 Smith's Wealth of Nations. 59 All of these works proposed that society had changed and was still in the process of changing. All but Kames' Sketches asserted that as a result of changes in society, law and government had also undergone alterations. ${ }^{60}$ Of course, it is difficult to determine the extent to which these writers were read or how they were interpreted, but the relatively high representation of these authors in surviving library and booksellers' lists clearly indicates at least that their ideas were available to Americans and even that they elicited some interest. ${ }^{61}$

57. Adair, supra note 53, at 95 .

58. Id. For the general influence of the Scots on American education, see D. SLOAN, ThE Scottish Enlightenment AND THE AMERICAN College IDEAL (1971). Although students probably read moral and philosophical volumes far more frequently than books on the historical sociology, they could not easily have escaped some knowledge of the latter.

59. Lundberg \& May, The Enlightened Reader in America, 28 AM. Q. 262 (1976). In 1775, Madison purchased a volume by Ferguson, probably his Essay. 1 I. BRANT, JAMES MADISON 77 (1941). Thirty-one lists had Ferguson's History of the Roman Republic. Id. At least four of the framers and ratifiers are known to have read The Wealth of Nations. L. Piscatelli, The Meaning of Direct Taxes in the U.S. Constitution (unpublished manuscript) citing, inter alia: Letter from James Madison to Thomas Jefferson, April 27, 1785, in 8 PAPERS of Thomas JefFerson 111 (1971); Letter from Rufus King to Elbridge Gerry, June 5, 1785, 1 LIFE AND CORRESPONDENCE OF RUfus KING 109 (1894); Stevens, Adam Smith and the Colonial Disturbances, in ESSAYS ON Adam Smith 203 (1975) (regarding B. Franklin); H. Ford, Alexander Hamilton 256 (1920). One writer defended the Constitution by citing Wealth of Nations for the proposition that in some cases a standing army is not dangerous to liberty. Civis Rusticus, Va. Independent Chronicle, Jan. 30, 1787, in 8 Documentary History, supra note 1, at 338. James Kent not a framer or ratifier - was reading the book during the autumn of 1787. Letter from James Kent to Nathaniel Lawrence, Nov. 9, 1787, in 14 DOCUMENTARY HisTORY, supra note 1, at 75.

60. Kames addressed the effects of social change upon the law less directly in his Sketches than in certain other works, but the American circulation of those other writings is as yet unclear. By 1773, at least two libraries in Virginia had his Historical Law Tracts, which had been published in 1758. W. BRYSON, supra note 51, at 59. The course of legal reading given to Ezra Stiles, Jr., included Kames' History of Law. C. WARREN, supra note 51, at 181. Robertson's histories, especially his account of Charles V, discussed the development of law in different stages of society. A similarly relevant English work was Gibbon's Decline and Fall (see ch. 44), which was on 11 of the 1700-1790 lists studied by Lundberg and May. Lundberg \& May, supra note 59.

61. Note that Ferguson's Essay and Kames' Sketches were republished in America in the 1770s. Hamilton was referring to a relatively well-known source when, in the last number of The 
Thus, Americans could make use of very mixed intellectual traditions on social and legal change - traditions which assumed at least two general approaches. Having been exposed to the older ideas of natural law, the notion of the ancient constitution, and civic humanist concerns for permanence, Americans were familiar with the concept of permanent, immutable law. On the other hand, a significant number of Americans, including many who played prominent roles in the framing and ratifying of the Constitution, had become acquainted with the theories of Hale and the Scots that society undergoes change - change that requires or causes a corresponding development of legal and governmental institutions. ${ }^{62}$ Americans could also find suggestions of adaptive law in the work of Montesquieu. By means of these various theories and their two conflicting approaches to legal and social change, Americans inherited, not a monolithic ideology, but competing ideas about the relationship between the law and social developments. ${ }^{63}$ As will be seen, the framers and ratifiers drew upon both approaches, turning to one for their understanding of constitutional law and to the other for their perspective on ordinary law.

Federalist, he quoted at length from Hume's essay on The Rise and Progress of the Arts and Sciences - an essay in which Hume discussed directly the improvements in government that occurred with the more general advancement of man. THE FEDERALIST, supra note 2, No. 85 (A. Hamilton), at 594. In the New York ratifying convention, Hamilton revealed a clear understanding of the relationship between the development of commercial wealth in England and assertions of political and legal rights there. See Hamilton in New York Ratification Convention, 2 J. Elliot, supra note 1, at 264, 354.

62. Also associated with this approach was the work of Brady and Montesquieu and some aspects of classical and civic humanist analysis.

63. The jumble of different intellectual influences is apparent in the writings of James Wilson, who relied on Hale and the Scots for accounts of how law changed with social development, but who also referred to ancient English law and natural law. The odd combination of perspectives, juxtaposing the authority of King Alfred with that of Lord Kames, seems awkward to modern readers, but it accurately reflected the diversity of views available to Americans.

Two relevant traditions not mentioned in the text were equity and the continental doctrine on reasons of state. Equity deviated from rules of law to prevent injustice. The continental doctrine did so to satisfy needs of state. These traditions did not address changes in society, but they both offered solutions to the legal problems caused by, among other things, a society that outgrew its law.

In addition, note that seventeenth- and eighteenth-century English writers on economic and social policy produced many pamphlets and books that often suggested - even if not always in theoretical terms - a relationship between law and social developments. The economic literature is discussed by W. Letwin, The Origins of Scientific Economics: English Economic Thought, 1660-1776 (1963); E. Heckscher, Mercantilism (1935). See also J. Appleby, Economic Thought and Ideology in Seventeenth Century England (1978); Appleby, Modernization Theory and the Formation of Modern Social Theories in England and America, 29 Comp. STUd. IN Socy. \& Hist. 259 (1978). But see Winch, Economic Liberalism as Ideology: The Appleby Version, 38 Econ. HIST. REv. 287 (1985). For a discussion of mercantilism and economic theory in the context of America and the legitimization of interest, see Matson \& Onuf, Toward a Republican Empire: Interest and Ideology in Revolutionary America, 37 Aм. Q. 496, 502 (1985). 


\section{The Newer Concept of a Constitution and the Idea of Permanence}

American analysis of the Constitution's relationship to social change was complicated by the existence of at least two different conceptions of a constitution. From one perspective, a constitution was the arrangement and nature of government, which was embodied in practice or in custom and law. Americans, however, had also inherited a somewhat different and relatively new understanding of a constitution, according to which a constitution consisted of express restraints on government. Although the two conceptions occasionally merged, they also could be distinct.

The newer understanding of a constitution developed over a long period but particularly in the seventeenth and eighteenth centuries through the combination of developments in both common law and natural law. During the seventeenth century, England's constitutional customs were widely considered fundamental law - law that restrained the government, including to some degree Parliament. ${ }^{64}$ England's dramatic constitutional struggles and the discussion of such events in terms of ancient legal custom gave importance and currency to English constitutional traditions and shaped them into powerful, albeit incomplete, limitations on government.

These English constitutional ideas were complemented by modern natural law treatises, which gave Americans a philosophical account

64. The importance of English legal traditions for the development of American constitutionalism has been suggested by Stanley Katz. Katz, The American Constitution: A Revolutionary Interpretation, in BEYOND CONFEDERATION, supra note 17, at 30, 36-37; see also Greene, From the Perspective of Law: Context and Legitimacy in the Origins of the American Revolution, $85 \mathrm{~S}$. ATL. Q. 56 (1986); Lutz, Bernard Bailyn, Gordon S. Wood, and Whig Political Theory, Pol. ScI. ReVr. 111 (Fall 1977); 1 \& 2 J. Reid, Constitutional History of the AMERICAN Revolution (1986-1987). Bernard Bailyn argues that the newer understanding of constitutional law developed chiefly in America in the 1770s. B. BAILYN, supra note 34, at 182-84. Katz points out, however, that Bailyn's account fails adequately to recognize the importance of earlier English constitutional struggles and ideas. The concept of constitutional limitations had a prominent history in England long before 1776. On constitutionalism in general, see Stourzh, Constitution: Changes in Meanings of the Term from the Early Seventeenth to the Late Eighteenth Century, in Conceptual Change and the Constitution 35 (T. Ball \& J. Pocock eds. 1988).

Consistent with Katz's point of view, it should be noted that the growth of Parliamentary sovereignty did not prevent many Englishmen from believing that the constitution placed some restraints on Parliament. Seventeenth-century opponents of Parliamentary power asserted that Parliament had violated the fundamental constitution. Even some who had once quarrelled with the Crown reacted to Parliamentary abuses by suggesting that Parliament was subject to constitutional restraints. See, e.g., C. McIlwain, The High Court of Parliament and Its SuPREMACY 86-92 (1910, reprinted 1962). The idea of fundamental restraints on Parliament survived into the eighteenth century, as can be illustrated by the arguments that Parliament violated the constitution by not having frequent elections. For example, see the protest of 31 peers against the Septennial Act (1716): "[W]e conceive that frequent and new parliaments are required by the fundamental constitution ...." SOURCES OF ENGLISH CONSTITUTIONAL HisTORY 623 (C. Stephenson \& F. Marcham eds. 1937). 
of fundamental law - a fundamental law established by the consent of the people and containing express reservations of rights. ${ }^{65}$ Older accounts of a natural law known through right reason had suggested that there could be limitations on the sovereign, although these restrictions were not typically perceived as enforceable. A newer version of "natural law," however, produced clearer ideas of enforceable constitutional protections for rights. Drawing on observations about human nature as revealed in a hypothetical state of nature, many postHobbesian writers argued that men formed governments to protect themselves. ${ }^{66}$ In the state of nature, men are subject to no common superior, and each enjoys a liberty guided only by what many writers

65. This discussion of the importance of contract theory for American constitutionalism reflects the conclusions of: Berns, supra note 48; J. APPLEBY, CAPITAlism AND A New Social Order: The RePublican Vision of THE 1790s 21 (1984); Howe, European Sources of Political Ideas in Jeffersonian America, 10 REVIEWS IN AMERICAN History 28, 32-33 (1982); Onuf, State Politics and Ideological Transformation: Gordon Wood's Republican Revolution, 44 WM. \& MARY Q. 612 (1987); Banning, Some Second Thoughts on Virtue and the Course of Revolutionary Thinking, in ConcePtuAl Change AND THE Constitution, supra note 64, at 194 (1988); M. White, The Philosophy of the American Revolution (1978); Kramnick, Republican Revisionism Revisited, 87 AM. HIST. REV. 629 (1982); Schmitt \& Webking, Revolutionaries, AntiFederalists, and Federalists: Comments on Gordon Wood's Understanding of the American Founding, Pol. Sci. Revr. 195 (Fall 1979); J. Diggins, The Lost Soul of American PoliTICS: VirTUe, SElf-INTEREST, AND THE Foundations of Liberalism (1984). Bailyn and, to a degree, Wood suggest that American notions of constitutional law were relatively original to Americans, that such ideas were developed during the Revolutionary period, and, most important, that they embodied the older, noncontractual natural law analysis at least as much as, if not more than, the modern contract theory. B. BAILYN, supra note 34, at 175-89; G. WooD, supra note 48, at 259-305; see also Grey, Do We Have an Unwritten Constitution?, 27 STAN. L. REV. 703, 715-16 (1975); Grey, Origins of the Unwritten Constitution: Fundamental Law in American Revolutionary Thought, 30 STAN. L. REV. 843, 891-92 (1978). In various ways, the other writers cited above in this note suggest another point of view.

Although some Americans of the Revolutionary and post-Revolutionary period did discuss constitutional law in terms suggestive of the older natural law analysis, they were in this regard hardly typical. Moreover, such of the older analysis as is apparent in American writings c. 17601790 is usually confused by those writings with the newer, contractual approach. (The controversy about the degree to which Locke's work on government was known to the colonists does not greatly affect this article's account of the American understanding of constitutional law, for Locke's was only one of a variety of natural law treatises that were studied here. In this regard, note that Lutz has recently suggested that Sidney was as important for Americans as Locke. D. Lutz, The Origins of American Constitutionalism 114 (1988).)

This article devotes more space here to the natural law than the common law influences on the American understanding of a constitution, because the natural law analysis may be less familiar. Also, to the degree that common law contributed to American perceptions of the content rather than the concept of a constitution, common law does not require as much discussion here as does natural law.

66. Of course, this article's brief characterization of the writers on the law of nature cannot even begin to describe the great variations among their opinions. Many of those who wrote after Pufendorf held opinions somewhat different than his. Typically, they accepted natural law as moral law binding in the state of nature but often did not emphasize to the same degree as Pufendorf that such law could be viewed as a description of how men pursue their individual interests. Note also that the ideas of a state of nature, of the natural desire and right to preserve oneself, and of government by consent were hardly novel in the seventeenth century. It was, however, in that century that they first were analyzed in a systematic way as the foundation for a contractual view of society and government. 
optimistically called "natural law." In the writing of Pufendorf, for example, natural law consisted of reasoned observations about human nature and enlightened self-interest that looked uncannily like some traditional moral obligations. A desire for self-preservation was the chief characteristic of human nature, and respect for the preservation of other men constituted self-interest. Inevitably, however, the latter truth was not recognized by all persons. Although, for Pufendorf and a great many eighteenth-century Englishmen and Americans, natural law was a binding obligation in the state of nature, "natural law" was, in the words of Pufendorf, "not strong enough to secure the peace of mankind." 67 It was for this reason that men agreed to enter society and submit to government. According to Pufendorf and various subsequent contractual writers, government at this point was merely nascent or primitive but sufficient to join the people in another contract called "fundamental" law. ${ }^{68}$ To obtain security, the people relinquished to government much of the liberty they possessed in the state of nature, but to protect themselves from their new government the people stipulated in the compact the liberty they reserved. Some writers seemed to suggest the compact would be in writing. ${ }^{69}$ Thus, natural law was transformed from precepts of moral knowledge known through right reason to a series of observations or assumptions about human nature, and from these it was apparent that men formed governments and constitutions by contract. ${ }^{70}$

Having long appreciated Magna Charta, the English Bill of Rights, and some colonial charters and constitutions, Americans were particularly receptive to the idea that constitutions could be created and written rather than inherited and rooted in custom. A created and written fundamental law that protected rights from even legislative infringement must have appeared to Americans to be, not an abstract theory, but an accurate description of their legal heritage, experiences, and needs.

As a result of the way in which it was studied, natural-law theory (especially the modern descriptions of the state of nature and contrac-

67. S. Pufendorf, De Jure Naturae et Gentium Libri Octo bk. VII, ch. i, sec. 11, at 965 (J. Scott ed. 1934).

68. Some writers were not so clear as to the number of contracts to be supposed. Moreover, some thought an indivisible sovereignty resided in the people.

69. Note that the word "constitution" contributed to expectations of a written document. See, e.g., J. Fortescue, De Laudibus Legum Anglie 37 (ch. XV) (1942).

70. Some writers, such as Locke, considered government to be a trusteeship. Most colonists, however, did not draw such fine distinctions among the various theories based on analysis of the state of nature. Note that, according to J.P. Reid, a form of contract theory was derived from common law sources. Reid, In Our Contracted Sphere: The Constitutional Contract, the Stamp Act Crisis, and the Coming of the American Revolution, 76 Colum. L. Rev. 21, 22 (1976). 
tual constitutions) seemed particularly applicable to questions of law. In the eighteenth century, in both England and America, modern natural law treatises were read as texts on morals and jurisprudence. ${ }^{71}$ Understood in this context, the modern natural law volumes were directly pertinent to practical problems of law and government and therefore, increasingly, could be cited as legal arguments without any sense of awkwardness. Thus, Blackstone began the first book of his Commentaries with a chapter explaining the rights of Englishmen in terms of the liberty existing in the state of nature. ${ }^{72}$ The jurisprudential study of modern natural law treatises encouraged lawyers and others to view such accounts as legal analysis.

What in England, however, justified the last revolution, in America could be used to justify the next. ${ }^{73}$ Whereas Englishmen employed natural-law contract theory to explain their customary constitution, Americans in the 1760 s and 1770 s were increasingly discontented with their position under that constitution and turned to the modern natural law analysis in their assertions of independence. ${ }^{74}$ More pertinent to this article, they could draw from their legal heritage and the modern natural law theory with which it so neatly coalesced the possibility of a newly created, written constitution that would restrain the legislature as well as the rest of government. ${ }^{75}$ Thus, when the constitutional crisis in America forced Americans to think about constitutions in an unusually concrete fashion, they were well prepared to have a clear understanding of a written constitution.

In the mind of anyone aware of the theories that recognized the

71. Stewart, Dissertation Exhibiting the Progress of Metaphysical, Ethical, and Political Philosophy, in 1 The Collected Works 93, 172-93 (1854, reprinted 1971); A. Haddow, PoLitic.Al SCIENCE IN AMERICAN Colleges AND UNiversities, 1636-1900 chs. 1-2, 4-6 (1939); C. Wordsworth, Scholae Academicae 121-32 (1877); Hamburger, The Development of the Nineteenth Century Consensus Theory of Contract, LAw \& HIST. REV. (forthcoming Fall 1989).

72. 1 W. Blackstone, Commentaries on the Laws of England 121-45 (1765). Blackstone was very cautious about the contractual analysis of government and constitutions, but he did summarize Locke's views. Id. at 52 .

73. Bailyn suggests that the application of natural law analysis to legal and constitutional issues was largely American and revolutionary. B. BAILYN, supra note 34, at 160-229. This would seem to be, at best, an incomplete view of the matter. See supra note 65 . Note also that modern natural law theory was used to justify resistance and even revolution in the 1680 s. See J. GougH, supra note 22, at ch. 9.

74. Cf. Katz, The American Constitution: A Revolutionary Interpretation, in BEYOND CONFEDERATION, supra note 17, at 23. Earlier, they had claimed the rights of Englishmen and for this purpose had had to use natural law theory only occasionally. Now, they rejected the English constitution and in so doing frequently employed modern natural law theory. Their apparently sudden adoption of arguments from modern natural law treatises was possible because they were already familiar with such treatises through their study of morals and jurisprudence.

75. It is no surprise that common law notions of constitutionalism could be integrated so neatly with ideas of contractual limitations on government, for both traditions developed in response to similar problems. 
existence of legal and social change, this newer concept of a constitution might have posed particularly difficult questions, for Americans by 1776 had come to believe that constitutions ought to be permanent. Drawing on the older view of natural law, the tradition of the ancient constitution, and civic humanism, Americans thought constitutional law should be permanent and unchanging. ${ }^{76}$ Permanency was precisely what had eluded republican constitutions or government in the past. Just as many Americans desired liberty and the republican nature of their governments to last permanently, so too they wanted the written limitations that embodied the principles of republicanism and liberty to endure.

In 1776, it was assumed that a constitution had to be permanent, in the sense of being lasting and even rigid, subject only to alteration by the people. ${ }^{77}$ It was necessary

that certain great first principles be settled and established, determining and bounding the power and prerogative of the ruler, ascertaining and securing the rights and liberties of the subjects, as the foundation stamina of the government; which in all civil states is called the constitution, on the certainty and permanency of which, the rights of both the ruler and the subjects depend. ${ }^{78}$

Constitutions not only were permanent but also were contrasted with "temporary laws." 79 Thus already in 1776, it was asserted that "[m]en entrusted with the formation of civil constitutions should remember that they are painting for eternity." 80

Various scholars have argued that Americans continued to hold such opinions after the Revolution. ${ }^{81}$ Cecelia Kenyon has shown that

76. In addition, note that corporate charters, including some colonial charters, could be described as "perpetual."

77. The relationship between social change and the newer concept of a constitution was to some extent considered by the authors of the post-Revolutionary state constitutions, but they apparently did not contemplate the possibility of far-reaching social change as directly as did the men of 1787 and 1788. For an account of their attitudes, see Kenyon, Constitutionalism in Revolutionary America, in Constitutionalism 84 (Nomos XX, J. Pennock \& J. Chapman eds. 1979).

78. M. MAther, America's Appeal 22-23 (1775), quoted in G. Wood, supra note 48, at 271. For Wood's and Bailyn's understanding of these quotations, see supra note 65 .

79. Four LetTers on IMPORTANT SubJects 16 (1776), quoted in B. BAILYN, supra note 34 , at $182-83$.

80. The Genuine Principles of the Ancient Saxon or English Constitution 34 (1776), cited in B. BAILYN, supra note 34 , at 184 . For more on the "many other statements of the idea of a fixed constitution published by 1776," see B. BAILYN, supra note 34 , at $182-84$ \& n. 25 .

81. While making final revisions, my attention has been drawn to M. LIENESCH, NEw ORDER OF THE AGES (1988). According to Lienesch, Federalists believed their scientific study of "balance" in politics gave them an opportunity to establish a perfect and permanent constitution. Id. at 134-35. Although Federalists did hope for a permanent constitutional law, and although many of them may have expected scientific study of human nature and politics to facilitate the drafting of a permanent constitution, the view that such permanence was largely the product of 
those who created the post-Revolutionary state constitutions hoped for lasting documents that would postpone the loss of liberty. ${ }^{82}$ These were to be constitutions that "no length of Time will corrupt and which will endure as long as the Sun and Moon . . . ."83 Later, in Marbury v. Madison, Marshall wrote that the "principles" of the Constitution "are deemed fundamental [and] permanent" and, except by means of formal amendment, "unchangeable." 84 From this starting point, Walter Berns has reconsidered the usual understanding of $\mathbf{M c}$ Culloch v. Maryland:85 "Marshall's meaning is not that the Constitution may be adapted to 'the various crises of human affairs,' but that the legislative powers granted by the Constitution are adaptable to meet those crises. .. . It was not Marshall's view that the Constitution must be kept in tune with the times ...."86 Although Berns discusses these ideas in connection with cases decided long after ratification of the Constitution, he implies that such views were held by the framers and ratifiers. ${ }^{87}$ Indeed, he goes on to examine modern natural-law analysis and concludes that late eighteenth-century Americans would have assumed constitutions were not subject to judicial adaptation.

It remains to be seen what the debates on the Constitution reveal. Did the framers and ratifiers think of constitutions as permanent? And how did they expect constitutions to accommodate social change? ${ }^{88}$

\footnotetext{
"balance" in politics or the Constitution does not appear to have been held by many framers or ratifiers. The notion of balance was far more important for the permanence of the constitution in the sense of the nature or arrangement of government than the constitution in the sense of the limitations on government. According to Lienesch, moreover, Anti-Federalists wanted rights to be "indelibly inscribed" in a constitution but were content to have such a constitution rewritten when it became "dated." Id. at 147. A rather different perspective may be found in Kenyon's work and also in this article. For Kenyon's views, see infra text accompanying note 82 . What Lienesch considers generally to be an Anti-Federalist position is here treated as the view of a minority.
}

82. Kenyon, supra note 77 , at 115 .

83. Id. This quotation referred to the Massachusetts Constitution.

84. Berns, supra note 48, at 52, quoting Marbury v. Madison, 5 U.S. (1 Cranch) 137, 176-77 (1803).

85. 17 U.S. (4 Wheat.) 316 (1819).

86. Berns, supra note 48 , at 52-53.

87. W.E. Nelson believes that the Constitution was viewed in the early nineteenth century as "intended to endure for ages to come." Nelson, Continuity and Change in Constitutional Adjudication (Book Review), 78 YALE L.J. 511 (1969) (quoting McCulloch v. Maryland, 17 U.S. 316, 415 (1819)).

88. Before examining the views of such persons as did trouble themselves to think about changes in society and how such changes might affect the Constitution, it is necessary very briefly to consider the possibility that many in the Convention and in the ratifying debates did not contemplate much social change or perhaps did not engage in much contemplation of any sort. Clearly, however, it would have been difficult for most framers and ratifiers to avoid knowing about at least some of the repeated arguments that American society might change, whether the Federalist argument that the Constitution would improve the American economy or the Anti- 
The framers and ratifiers did assume that constitutions should be permanent. Anti-Federalists took a perspective similar to that which Kenyon detected among earlier constitution-makers, and Federalists held views similar to those found by Berns in the opinions of Marshall. What supporters and opponents of the Constitution had in common was that both anticipated the possibility of great change in American society and nevertheless believed that constitutions were to be permanent. They assumed that constitutions were to be unchanging and inflexible in response to social development. ${ }^{89}$

\section{Anti-Federalists on the Constitution aNd Social Change}

Most Anti-Federalists thought that a constitution and the republican nature of government should be made as permanent as possible, notwithstanding the probability of social change. Rather than attempt to accommodate social change, however, as did the Federalists, AntiFederalists frequently sought to defy it.

\section{A. The Permanency of Liberty and Republican Government}

The effect of social change upon the permanency of liberty and republican government in America is a common theme in Anti-Federalist writings and speeches. Even if the Constitution, in the sense of its formal, written limitations, were to survive, there was still a possibility that a republican constitution would cease to exist, that the government would no longer be republican in nature. In the past, republican governments had been notably short-lived. Anti-Federalists argued that the Constitution - that is, the Constitution as drafted rather than a constitution as it ought to be - would lead to equally dire results, in part as a result of the changes the Constitution would encourage in American society.

Drawing on the tradition of civic humanism, many Anti-Federalists argued that the foundations of civic virtue and republican government were precarious; specifically, they complained that the Constitution itself would encourage social change inimical to republi-

Federalist argument that the Constitution would encourage the corruption of American manners. Since these issues will be examined in some detail later in this article, it will suffice at this point to note that the possibility of considerable changes in American society was widely discussed in connection with the new Constitution.

89. Note, parenthetically, that it is convenient in the next two parts of this article to examine the views of Americans on the accommodation of social change both in connection with the traditional conception of a constitution as the arrangement or nature of the government (generally expected to be republican) and in connection with the newer conception that a constitution was a written constraint on government. 
canism. The Constitution, as presented for ratification, would permit or accelerate a decline in virtue and thereby would cause a revolution in American morals. Commenting on the Anti-Federalists, the historian Herbert Storing has written:

Wherever they looked in the new Constitution the Anti-Federalists saw threats to civic virtue. The federal city provided for would breed monarchical institutions and courtly habits, with their oppressive tendencies and with the effect "above all [of] the perpetual ridicule of virtue." The standing army would be not only a potential instrument of oppression but a source of moral corruption. With interests and habits different from the rest of the community, a standing army "will inevitably sow the seeds of corruption and depravity of manners. Indolence will increase, and with it crimes cannot but increase. The springs of honesty will gradually grow lax, and chaste and severe manners be succeeded by those that are dissolute and vicious. When a standing army is kept up, virtue never thrives." Commerce itself . . . seemed to threaten republican simplicity and virtue. Commerce is the vehicle of distinctions in wealth, of foreign influence, and of the decline of morals. ${ }^{90}$

Some qualifications of Storing's view are necessary. The Anti-Federalist argument that the Constitution would undermine civic virtue was rarely if ever put forth with as much completeness, clarity, and coherence as it was by Storing. On a narrower point, Anti-Federalists may have worried more about commerce with foreign nations and particularly the danger of foreign luxuries than about commerce itself. ${ }^{91}$

Notwithstanding these caveats, many Anti-Federalists did argue that the Constitution would promote social changes dangerous to virtue. Opponents of the Constitution insisted that it would contribute to the development of an aristocratic social and political elite, consisting of the wealthy, the talented, and the well-connected, who would obtain most federal offices and reside in the federal city. Under the Constitution, this aristocracy would be one of a multiplicity of distinct interests, the very existence of which would threaten virtue and the republicanism of the government. ${ }^{92}$

Anti-Federalists' arguments, however, did not reflect exclusively the ideas of civic humanism; their arguments about social change, like

90. $1 \mathrm{H}$. STORING, supra note 1 , at 20-21 (footnotes omitted).

91. See, e.g., Williams in New York Ratification Convention, June 21, 1788, in 2 J. EllioT, supra note 1, at 240; Locke in North Carolina Ratification Convention, July 31, 1788, in $4 \mathrm{~J}$. ELLIOT, supra note 1, at 239.

92. Such a government would not rest on a permanent social foundation and so could not itself be permanent. E.g.: "There can be no fixed and permanent government that does not rest on the fixed and permanent orders and objects of mankind." Essays by a Farmer, in 5 H. STORING, supra note 1, at 43; see also id. at 42. "If there are advantages in the equal division of our lands, and the strong and manly habits of our people, we ought to establish governments calculated to give duration to them . ..." Observations . . in a Number of Letters from the Federal Farmer... . in 2 H. STORING, supra note 1, at 251 [hereinafter Letters from the Federal Farmer]. 
their other attacks on the Constitution, drew upon a varied intellectual heritage, including seventeenth-century English traditions suspicious of power as an instrument of tyranny. ${ }^{93}$ For example, the creation of a Federal elite was feared not only as a threat to independence and virtue but also because of its more directly political consequences. Among other things, such an elite would impoverish the people by its extravagant emoluments and would deprive ordinary citizens of political power. ${ }^{94}$ A related development feared by Anti-Federalists for its political effects was the creation of a powerful and potentially oppressive federal government. Independently of analysis developed from civic humanism, such a government would endanger liberty.

Whether by undermining the social foundations of virtue or by introducing changes in society that invited abuses of power, the Constitution would, according to Anti-Federalists, encourage alterations in American society inimical to the preservation of republican government and liberty. Anti-Federalists thus argued on the assumption that it was possible to prevent or at least delay social changes that would challenge "the permanency and duration of free government." 95

\section{B. The Permanent Constitution}

Anti-Federalist arguments against the Constitution reveal some distinct expectations about the relationship between social change and constitutional law. In the minds of many Americans, including AntiFederalists, liberty and republican government could be permanently established only by means of permanent constitutional protections. ${ }^{96}$ Thus, although Anti-Federalists did not want the proposed constitution to take effect or to last, they considered a permanent constitution essential.

93. See generally C. Kenyon, The Anti-Federalists xxi-cxvi (1966); Katz, The American Constitution: A Revolutionary Interpretation, in BEYOND CONFEDERATION, supra note 17, at 23; T. Pangle, supra note 35; Banning, Some Second Thoughts on Virtue and the Course of Revolutionary Thinking, in ConCEPTUAL Change AND ThE CONSTITUTION 194 (T. Ball \& J. Pocock eds. 1988) [hereinafter Banning, Second Thoughts]; Wood, Interests and Disinterestedness in the Making of the Constitution, in BEYOND CONFEDERATION, supra note 17, at 69; see also supra note 64 . The disproportionate space devoted in this section to the tradition of civic humanism does not reflect a judgment that Anti-Federalists drew on it more than on the English political and legal traditions that were intertwined with civic humanism. Rather, the civic-humanist strain in Anti-Federalist arguments requires greater attention here because it more directly addressed the effects of social change.

94. C. KENYON, supra note 93.

95. Letters from the Federal Farmer, in 2 H. STORING, supra note 1, at 329. According to the Federal Farmer, "[i]f it is not . . . in our power to preserve republican principles, for a series of ages, in all the departments of government, we may a long while preserve them in a well formed legislature." Id. at 304 .

96. In this respect, civic humanism and hopes for republican government had become associated with contractual and common law notions of constitutional restraints. 
Some Anti-Federalists acknowledged that the country would gradually change even if the Constitution were not adopted and that when such change occurred a substantial alteration in government might be appropriate. Thus, Grayson of Virginia expected an "American character" to develop but felt that, "[w]e are yet too young to know what we are fit for." 97 America, he thought, was not sufficiently populated on the frontiers to justify "making new experiments now in government." Citing Montesquieu, he insisted on the need for "the construction of government [to] be suitable to the genius and disposition of the people, as well as a variety of other circumstances."98 He believed that one day "the American character" would be "better known, and the government established on permanent principles. ..." Only then, for example, would a fleet be appropriate. ${ }^{99}$

Similarly, Harrison, also of Virginia, argued:

I see an earnest desire in gentlemen to bring this country to be great and powerful. Considering the very late period when this country was first settled, and the present state of population and wealth, this is impossible now. The attempt will bring ruin and destruction upon us. These things must not be forced. They must come of course, like the course of rivers, gently going on. ${ }^{100}$

Harrison did not deny the possibility of future greatness and power for America, but he anticipated gradual change and did not want a powerful national government before America was ready for it. ${ }^{101}$

97. Grayson in Virginia Ratification Convention, June 11, 1788, in 3 J. ElLIOT, supra note 1, at 278 .

98. Id. at 279.

99. I hope that ... all ideas of having a fleet, in our infant situation, will be given over. When the American character is better known, and the government established on permanent principles, - when we shall be sufficiently populous, and our situation secure, - then come forward with a fleet; not with a small one, but with one sufficient to meet any of the maritime powers.

Id. at 289 .

100. Harrison in Virginia Ratification Convention, June 25, 1788, in 3 J. Elliot, supra note 1 , at 629 .

101. For another example of this perspective, see Letter from W.S. Smith to Thomas Jefferson, Dec. 3, 1787, in 12 Papers of Thomas JefFerson 390 (1955). One Federalist commentator attributed such arguments to artful opponents of the Constitution. Such Anti-Federalists said

that it appears to them, such a system of perfection is more than we ought to aim at, at present; and that it is their opinion, such noble regulations are rather calculated for a country that has had a long career of glory and greatness, than for one which is but wishing to make a beginning - and many of them add they do not believe it will go down, as they doubt whether there is yet virtue enough in America to support so good a government.

One of the People, Mass. Centinel, Oct. 17, 1787, in 13 Documentary History, supra note 1, at 393. Pinckney used a similar argument for other purposes:

Much has been said of the constitution of G[reat] Britain. I will confess that I believe it to be the best constitution in existence; but at the same time I am confident it is one that will not or can not be introduced into this Country, for many centuries.

Pinckney, Draft Speech, June 25, 1787, in M. FarRAND, supra note 1, at 115 (Supp. 1987). 
Anti-Federalists could even go so far as to abandon the ideal of a permanent constitution. In language that blended the notion of popular sovereignty and Scottish ideas on social and legal development, one Anti-Federalist noted that governments tended not to hold "the same progressive tenor with the society," and argued for the preservation of "the inestimable right of having in our power at all times to new model our government according to circumstances, and to vary its course at certain periods; since it is really in this power that the sovereignty of the people consists." ${ }^{102}$ Another Anti-Federalist took less pleasure in recognizing

the impossibility of framing a good constitution on any one invariable foundation so firmly as never to be shaken. The best that can be devised will at last be vitiated by the corroding hand of time, and can only be kept pure by continually modifying it according to circumstances .... ${ }^{103}$ This was, he thought, a "melancholy truth." 104

In general, however, Anti-Federalists insisted that constitutions should permanently establish in writing the limitations fundamental to liberty and republican government. According to Anti-Federalists, a bill of rights was necessary to "secure" liberty for their "posterity" or "for ages to come." 105 A "Georgian" wrote: "Let your suffrages at elections never be suffered to be regulated by laws at pleasure, but let it be stated and fixed. Let the trial by jury in civil and criminal cases, and the liberty of the press, be forever sacred and inviolable."106 "Cato" explained that, on the one hand, a constitution "fixes barriers which the ambitious and tyrannically disposed magistrate dare not overleap, and on the other, becomes a wall of safety to the community. . .."107 Cato argued that such a barrier, consisting of precise limitations in the Constitution, would be especially necessary for the protection of liberty if American society were to change: "It is alleged that the opinions and manners of the people of America are capable to resist and prevent an extension of prerogative or oppression, but you must recollect that opinion and manners are mutable, and may not

102. Letter From a Delegate Who Has Catched Cold, in 5 H. STORING, supra note 1, at 269, 271. He also wrote: "If all the nations of Europe the more civilized, were in possession of such a regulation, they should not lament certainly under ridiculous and barbarous laws, institutions and customs, which are in contradiction with their actual morals and their learning." Id. at 271.

103. A True Friend, Dec. 5, 1787, in 8 Documentary History, supra note 1, at 219.

104. Id.; see also infra text at note 137. For the relationship between such sentiments and the amendment process, see infra text at note 226.

105. Such sentiments, moreover, continued to be expressed after ratification of the Constitution. See, e.g., 1 First Federal Elections, supra note 1, at 239, 260, 278 (Pa.); 1 id. 454 (Mass.); 3 id. 414 (N.Y.).

106. A Georgian, Gazette of the State of Georgia, Nov. 15, 1787, in 3 DocumenTARY HisTORY, supra note 1, at 243.

107. Clinton, Letters of Cato, in P. Ford, Essays, supra note 1, at 266. 
always be a permanent obstruction against the encroachments of government . . . ."108 According to James Monroe, "The spirit of the times might secure the people of America perhaps for a great length of time against it; but fundamental principles form a check, even when the spirit of the times hath changed, indeed they retard and controul it." 109 Anti-Federalists sought to establish liberty and republican government not only on mutable and possibly inadequate social foundations but also on what appeared to them to be the more permanent guarantee of enduring and inflexible constitutional limitations. ${ }^{110}$ It has been seen above that Anti-Federalists objected to the Constitu-

108. He continued: "that the progress of a commercial society begets luxury, the parent of inequality, the foe to virtue, and the enemy to restraint; and that ambition and voluptuousness, aided by flattery, will teach magistrates where limits are not explicitly fixed to have separate and distinct interests from the people ...."Id. at 266.

109. Monroe, Some Observations on the Constitution, in 5 H. STORING, supra note 1, at 292. For similar sentiments, see Letter from Joseph Spencer to James Madison, Feb. 28, 1788, in 16 DOCUMENTARY HISTORY, supra note 1, at 252, 254.

110. In a comment that suggested not only his own views, Madison observed that a bill of rights would "satisfy the public mind that their liberties will be perpetual." 2 B. SCHWARTZ, BILl of Rights, supra note 1, at 1025-26. According to Patrick Dollard of South Carolina, his constituents wanted a bill of rights, "ascertaining and fundamentally establishing, the unalienable rights of men . ..." Dollard in South Carolina Ratification Convention, May 20, 1788, in 4 J. Elliot, supra note 1, at 337. Another Anti-Federalist argued: "In entering into the social compact, men ought not to leave their rulers at large, but erect a permanent landmark by which they may learn the extent of their authority, and the people be able to discover the first encroachments on their liberties." R. Whitehall in Pennsylvania Ratification Convention, Nov. 28, 1787, in 2 Documentary History, supra note 1, at 393. According to Agrippa, "It is an excellence that it should be permanent, otherwise we are exposed to perpetual insecurity from the fluctuation of government." [Winthrop?], Letters of Agrippa, in P. FORD, EsSAYS, supra note 1, at 116. Jefferson wrote to Donald in 1788 that bills of rights are "fetters against doing evil, which no honest government should decline." Rumble, James Madison on the Value of Bills of Rights, in ConSTITUtionalism 128 (Nomos XX, J. Pennock \& J. Chapman eds. 1979). According to the Federal Farmer, "it is fit and proper to establish, beyond dispute, those rights which are particularly valuable to individuals, and essential to the permanency and duration of free government." Letters from the Federal Farmer, in 2 H. STORING, supra note 1, at 329. A bill of rights was "never to be infringed or altered." An Old Soldier, Conn. Gazette, Jan. 4, 1788, in 15 DocumENTARY History, supra note 1, at 258; see also Cassius, To the People of the State of New York, County Journal, March 3, 1789, in 3 First Federal Elections, supra note 1, at 438; An Impartial Citizen, Petersberg Va. Gazette, Jan. 10, 1788, in 8 Documentary History, supra note 1, at 293. Note that R.H. Lee wrote of the Constitution's failure to provide for juries in civil cases that "[t]he evil is found resting upon constitutional bottom, and the remedy upon the mutable ground of legislation, revocable at any annual meeting." Letter of R.H. Lee to Governor Edmund Randolph, Oct. 16, 1787, in 5 H. STORING, supra note 1, at 115; see also Letter from R.H. Lee to J. Gordon, Feb. 26, 1788, in 8 DocumentaRY History, supra note 1, at 418-19; Letter from W. Russell to W. Fleming, Jan. 25, 1788, in 15 DocumentaRY History, supra note 1, at 468 .

Anti-Federalists frequently said that Americans were preparing a constitution for posterity, the ages, or millions yet unborn. See e.g., Randall in Massachusetts Ratification Convention, Jan. 17, 1787, in 2 J. ElliOT, supra note 1, at 40; Letters from the Federal Farmer, in $2 \mathrm{H}$. STORING, supra note 1, at 249; Essays by Candidus, in 4 id. at 130; Essays by DeWitt, in 4 id. at 18; Essay by $A$ Newport Man, in 4 id. at 253; Essays of An Old Whig, in 3 id. at 39. The Rev. James Madison hoped for forms of government with "that Permanence which, if possible, may be everlasting." Letter from the Rev. James Madison to James Madison, June 11, 1787, 10 PAPERS OF JAMES MADISON 45. 
tion's propensity to encourage dangerous developments in American society and argued instead for a constitution that would not facilitate and, perhaps, would even forestall such social change. Here, it has become apparent that they also wanted a constitution that would establish liberty and republican government in spite of social change.

Federalists frequently recognized that Anti-Federalists were attempting with "paper barriers" to protect what could survive only during the continuance of virtue and a spirit of liberty. ${ }^{11}$. Anti-Federalists were seeking in part to stave off the political consequences of social change with "parchment provisions." This was futile, according to Federalists, because the survival of liberty depended upon foundations more substantial than written restraints. Moreover, such restraints might soon become obsolete. For example, when defending the Constitution's apportionment clause, which permitted considerable congressional discretion, Hamilton argued:

[T]his matter, sir, depends on circumstances. It is impossible, in the first instance, to be precise and exact with regard to the number; and it is equally impossible to determine to what point it may be proper in future to increase it. On this ground I am disposed to acquiesce. In my reasonings on this subject of government, I rely more on the interests and opinions of men, than on any speculative parchment provisions whatever. I have found that constitutions are more or less excellent as they are more or less agreeable to the natural operations of things. ${ }^{112}$

Hamilton scoffed at Anti-Federalists' reliance on written provisions and particularly at their reliance on provisions that disregarded the possibility of changes in American society.

\section{Federalists on the Constitution and Social Change}

Although Federalists (including most framers) shared with AntiFederalists an expectation that a constitution should be rigid, that it should permanently establish fundamentals essential to liberty and republican government, they feared that many of what Anti-Federalists considered fundamentals would in fact be rendered obsolete by

111. See, e.g., Dickinson, Letters of Fabius, in P. Ford, PAMPhlETS, supra note 1, at 186; Webster, Government, 1 AM. MAG. 137, 140 (1788); Uncus, Md. Journal, Nov. 9, 1787, in 14 DOCUMENTARY History, supra note 1, at 77-78, 81; THE Federalist, supra note 2, No. 83 (Hamilton), at 564; The Federalist, supra note 2, No. 84 (A. Hamilton), at 580; Letter from James Madison to Thomas Jefferson, Oct. 17, 1788, in 11 PAPERS OF JAMES MAdison 297; Letter from G.L. Turberville to James Madison, April 16, 1788, in id. at 24; Letter from G.L. Turberville to James Madison, June 16, 1789, in 12 id. at 224-25. When Jefferson argued in favor of occasional "rebellion," he was expressing an extreme version of the belief that liberty requires more than paper protections. Letter from Thomas Jefferson to W.S. Smith, Nov. 13, 1787, in 14 DOCUMENTARY HISTORY, supra note 1, at 464-65.

112. Hamilton in New York Ratification Convention, June 21, 1788, in 2 J. ElLIoT, supra note 1 , at 251. 
change. ${ }^{113}$ Whereas Anti-Federalists argued for including various rights and other provisions in the Constitution in order to make those provisions permanent, Federalists often attempted to exclude such provisions in order to preserve the permanence of the Constitution. Federalists emphasized that a permanent constitution could not be written in a way that made it depend upon temporary circumstances. In many instances, they hoped that a potentially obsolete provision or phrase could be reformulated or adjusted to make it consistent with permanence. What could not be made permanent through this process of tinkering had to be excluded altogether and left to federal or state discretion.

\section{A. The Permanency of Liberty and Republican Government}

Like their opponents, Federalists frequently expressed a desire to establish liberty and republican government as permanently as possible. Federalists, however, platitudinously repeated that only ratification of the Constitution could protect or establish those objectives for posterity. ${ }^{114}$ They took a very different view than did Anti-Federalists of future changes in American society and of the means of preserving liberty and republican government.

Federalists did not contemplate the future more than Anti-Federalists, but, when describing what they saw, Federalists tended to use a more positive rhetoric than did their opponents. Anti-Federalists were perfectly capable of discussing future changes in society. Some even argued that American society would develop progressively, if the Constitution were not adopted. Perhaps because of their personal convictions, however, and certainly because of their position in the ratification debate, Anti-Federalists frequently employed the traditional rhetoric of civic humanism, which associated social change with

113. On the use of "Federalists" in this article to include most framers, see supra note 1. It will be seen that the framers and Federalists simultaneously shared and qualified different aspects of the Anti-Federalist argument that the Constitution should permanently establish the essentials of liberty and republican government. The idea that the Constitution should establish and fix such essentials probably appealed to almost all framers and ratifiers, including Federalists. Federalists, however, simultaneously had a more complex response to social change and threats to liberty.

114. For example, Randolph said in the Virginia Ratification Convention: "We became contemptible in the eyes of foreign nations; they discarded us as little wanton bees, who had played for liberty, but had no sufficient solidity or wisdom to secure it on a permanent basis . . ." $3 \mathrm{~J}$. Elliot, supra note 1, at 27. In the Pennsylvania Convention, Wilson said that the framers had aimed to establish a government "by which the peace, freedom, and happiness of the United States should be permanently insured." 2 DOCUMENTARY History, supra note 1, at 348 . A great many other statements simply referred to preserving republican government or liberty for posterity. 
moral and political decay. As a result, they appeared to be, at the least, ambivalent about social change.

In contrast, Federalists often argued that positive developments were possible, if the Constitution were to be ratified. They typically agreed with Anti-Federalists that virtue had a role in preserving liberty and republican government, ${ }^{115}$ but they did not rely as much upon the analysis of civic humanism. Although far from uniformly optimistic, they hardly perceived the Constitution as a threat to virtue or liberty. ${ }^{116}$ Some Federalists argued that social change was inevitable and even occasionally assumed it was progressive. Wilson's Scottish views on this subject have already been discussed. ${ }^{117}$ But he was not alone. A number of proponents of the Constitution asserted the progressive nature of the science of politics and their confidence that the new document was better drafted than any previous form of government. ${ }^{118}$ It would, they said, promote wealth and prosperity.

115. Federalists tended to argue that the Constitution could not guarantee liberty in the absence of virtue. See, e.g., Madison in Virginia Ratification Convention, June 20, 1788, in 3 J. Elliot, supra note 1, at 536-37; Ellsworth, The Landholder, VI, The Connecticut Courant, Dec. 10, 1787, in P. ForD, EsSAYS, supra note 1, at 166; The Republican: To the People, The Connecticut Courant, Jan. 7, 1788, in 3 Documentary History, supra note 1, at 527-28; Letter from John Trumbull to Jonathan Trumbull, Jr., Feb. 26, 1788, in 16 DocumentaRY HisTORY, supra note 1, at 213-14; Letter from George Washington to the Marquis de Lafayette, Feb. 7,1788 , in $i d$. at 70 . Hamilton thought that the preservation of rights depended upon public opinion and the spirit of the people and government rather than upon "fine declarations." THE FEDERAlist, supra note 2, No. 84 (Hamilton), at 580. Madison's views on virtue are discussed by Banning, Second Thoughts, supra note 93, at 194, 206-07. See also supra note 111.

116. Moreover, in reaction to the dire predictions of Anti-Federalists, Federalists occasionally questioned the possibility of anticipating the future and expressed a willingness to accept some small risks. In the Connecticut Ratification Convention, Governor Huntington responded to Anti-Federalist claims that the Constitution would undermine republican government:

The Author of Nature has given to mankind a certain degree of insight into futurity. As far as we can see a probability that certain events will happen, so far we do well to provide and guard. But we may attempt to go too far; it is in vain to think of providing against every possible contingency.

Huntington in Connecticut Ratification Convention, Jan. 9, 1788, in 3 DocumentaRY HisTORY, supra note 1, at 556. Similarly, a letter in the Connecticut Courant admitted of the Constitution that "we pretend not to foresee all the consequences which may follow from its reception," and then argued that "[a]ll ... we can know is that the new plan of government appears to be well calculated to secure our liberty .... [W] are willing to run the small risk occasioned by our ignorance of future events . . . ." To the Honorable Richard Henry Lee, Esquire, The Connecticut Courant, Dec. 24, 1787, in 3 id. at 511.

117. See supra text accompanying notes 54-55.

118. In the debates about the Constitution, Federalists had little reason to discuss progress outside of the context of the Constitution, but on occasion they did discuss progress generally. In criticizing the debating tactics of some delegates to the Connecticut Ratification Convention, one commentator wrote:

[A]s there is and ever has been a constant revolution in all manners, habits, and customs, either ancient or modern, some in quicker and others in a more dull succession, we hope upon this principle the time is come for the passing away of this baneful usage, a custom not less barbarous in society than the hideous daubings of the tawny tribes.

The People, New Haven Gazette, Oct. 11, 1787, in 3 DocumentaRy History, supra note 1, at 360. Wilson anticipated that America "may take the lead in literary improvements" and that the language of the United States was the one that "shall become most generally known in the civi- 
Some argued it would produce an extensive empire and future national importance. Moreover, the Constitution would encourage rather than undermine virtue. By prohibiting state issuances of paper money and breaches of contract, the Constitution would remove temptations to selfish, immoral, and politically dangerous conduct.

Among the Federalist attempts to preserve liberty and republican government in the face of insufficient virtue, Madison's analysis of factions has become particularly well known. In Federalist Number 10, he observed that "[a] landed interest, a manufacturing interest, a mercantile interest, a monied interest, with many lesser interests, grow up of necessity in civilized nations ...." Civilized societies would divide into interests according to "the various and unequal distribution of property" and for this and other reasons would fall prey to the factionalism that had undermined liberty in every previous democracy and republic. ${ }^{119}$ As is widely familiar, Madison believed an extended republic could avoid some of the dangers of factions and thereby help to secure liberty and republican government.

Much of Madison's analysis of factions was designed to remedy a problem that had, he understood, first developed in the distant past. His approach also sought, however, to preserve republicanism and liberty from dangers that might develop in the future. According to Madison, factionalism might increase in the United States ${ }^{120}$ but would be its own cure. ${ }^{121}$ The undesirable consequences of factions would tend to dissipate in the extended republic. ${ }^{122}$

lized world," thereby imparting "great importance over the nation [the United States] that shall use it." The "great improvements" made by America in the science of government "will induce the patriots and literati of every nation to read and understand our writings on that subject, and hence it is not improbable that she will take the lead in political knowledge." Wilson in Pennsylvania Ratification Convention, December 11, 1787, in 2 DocumenTARY HisTORY, supra note 1, at 582. No doubt Wilson took special pleasure in contemplating the world-wide appreciation of "our writings."

119. The Federalist, supra note 2, No. 10 (Madison), at 59. As Adair has shown, Madison derived this analysis from Hume. Adair, supra note 53, at 98-106. For an interesting comparison with Federalist No. 10 and No. 51, see Ferguson's analysis of interests and liberty, including his balance-of-power analogy. A. FERguson, AN ESSAY ON THE History OF CiviL SOCIETY 208, 265 (pt. III, secs. 2 \& 6 (1809)).

120. Madison wrote: "The latent causes of faction are thus sown in the nature of man; and we see them every where brought into different degrees of activity, according to the different circumstances of civil society." THE FEDERALIST, supra note 2, No. 10 (Madison), at 58.

121. "The degree of security ... will depend on the number of interests and sects; and this may be presumed to depend on the extent of country and number of people comprehended under the same government." THE Federalist, supra note 2, No. 51 (Madison), at 352.

122. Id. at 351-52. Carol Weisbrod suggests that Madison did not condemn all interest groups. See Weisbrod, Toward a History of Essential Federalism: Another Look at Owen in America, 21 U. CONN. L. REV. (forthcoming 1990). 


\section{B. The Permanent Constitution}

Having examined some Federalist ideas about how the republicanism of the new government could withstand changes in American society, this article can now inquire how Federalists thought the provisions of the Constitution could survive such changes. Not only did Federalists want permanency for republican government in America but one of the means by which they sought to achieve a lasting republicanism was the establishment of permanent constitutional limitations - ones that would avoid obsolescence. Many Federalists understood that American society might (in both the near and distant future) undergo alterations of considerable magnitude and therefore desired a constitutional law that would survive those transformations.

The Federalist perspective was based on widely held assumptions about the difference between constitutional and ordinary law - a distinction between law that was permanent and law that was mutable, between that which could be fundamental and that which varied according to circumstances. Rules that had to be mutable required the flexibility of ordinary law. Moreover, they did not belong in the Constitution; if included in that document, they would undermine it. Therefore, Federalists endeavored to exclude from the Constitution such rules and structures as would need to be adapted flexibly to changes in American society.

This is not to say that Federalists had uniform expectations about the Constitution's durability. Some spoke of decades; others, of centuries. As will be seen, however, almost all Federalists hoped that the Constitution's provisions would be permanent. In creating the Constitution, the framers took great care to formulate it in a way that would, they hoped, permit it to last almost indefinitely, and Federalists defended the document on the ground that it had, indeed, been framed for the future. ${ }^{123}$

123. A few pessimistic opinions about the period of time the Constitution would last have recently been cited with some frequency. Many other statements were very optimistic. Whatever their varied expectations about the time the Constitution would actually remain in effect, Federalists sought a document that could be permanent. (Note that discussions of apportionment prompted many of the recorded predictions about the Constitution's longevity.)

Both Federalists and Anti-Federalists assumed constitutions should be permanent. Since the latter did not like the 1787 Constitution, they hoped it would not last but expressed fears that it would. In contrast, Federalists started with the same assumption about constitutions in general but on occasion feared that the Constitution would not survive very long.

Incidentally, discussions about how the Constitution could accommodate social change were occasionally intertwined with debates about how republican government could survive such change. Therefore, although this Part of this article concerns the Constitution, the republican nature of the government will also at some points be examined. 


\section{General Statements}

The Federalists, and perhaps many of the framers, were well aware of the dangers of not anticipating change, for it was, in part, the lack of foresight of those who had prepared the Articles of Confederation that made the 1787 Convention necessary. The Convention had been called to prepare such alterations as would "render the federal constitution adequate to the exigencies of Government $\&$ the preservation of the Union." 124 At the beginning of the Convention, Randolph spoke of the "defects of the confederation" and in so doing turned to the exigencies that had been unanticipated by that document:

$[\mathrm{H}] \mathrm{e}$ professed a high respect for its authors, and considered, them as having done all that patriots could do, in the then infancy of the science, of constitutions, \& of confederacies, - when the inefficiency of requisitions was unknown - no commercial discord had arisen among any states - no rebellion had appeared as in Mass[achusetts] — foreign debts had not become urgent - the havoc of paper money had not been foreseen - treaties had not been violated - and perhaps nothing better could be obtained from the jealousy of the states with regard to their sovereignty. ${ }^{125}$

The framers of the Constitution were meeting precisely in order to cure the obsolescence of the existing constitution. ${ }^{126}$

The Constitutional Convention as a body made hardly any general statements of political theory either in the Constitution or elsewhere, yet a desire for a permanent constitution was the subject of some general statements by official groups belonging to the Convention. In language similar to that which was eventually used by Anti-Federalists, the North Carolina delegates wrote to Governor Caswell in June 1787 that a union of states "preserving their Civil Liberties and connected together by such Tyes as to Preserve permanent \& effective Governments . . . is a Circumstance that has not Occurred in the History of men . . .."127 Nevertheless, the permanence of both liberty and gov-

124. Resolution of Congress, Feb. 21, 1787, in 3 M. FARRAND, supra note 1, at 14. $18-19$.

125. Convention Notes of James Madison, May 29, 1787, in 1 M. FARRAND, supra note 1, at

126. Newspaper commentaries were even more explicit than the above quotations. As the Convention was gathering, a Baltimore newspaper noted, "The articles of confederation ... were as wisely drawn as the then situation of the country would permit: . . our attention was naturally absorbed, by objects of magnitude that surrounded us, while only time and reflection, could make us acquainted with more important ones at a distance." Baltimore Maryland Gazette, May 22,1787 , in 13 Documentary History, supra note 1, at 112. In June, a Philadelphia newspaper remarked: "The present Confederation may be compared to a hut or tent, accommodated to the emergencies of war - but it is now time to erect a castle of durable materials . . ." Philadelphia Independent Gazetteer, June 27, 1787, in 13 DocumentaRY History, supra note 1, at 148.

127. Letter from North Carolina Delegates to Gov. Caswell, June 14, 1787, in 3 M. FARRAND, supra note 1 , at 46. 
ernment was the North Carolinians' hope. Among the documents of the Committee of Detail is a draft of the Constitution (in the writing of Randolph and corrected by Rutledge). ${ }^{128}$ It begins with the only surviving general discussion by the Committee or its members about how to draft a constitution: "In the draught of a fundamental constitution, two things deserve attention," the first being: "To insert essential principles only, lest the operations of government should be clogged by rendering those provisions permanent and unalterable, which ought to be accommodated to times and events." 129 The key to the writing of a constitution was not just the inclusion of "essential principles" a goal Federalists and Anti-Federalists shared - but also the exclusion of anything that would have to be accommodated to later times and events. Like many other Federalists, the authors of this document apparently made the optimistic assumption that the provisions that would have to change with time - and therefore had to be excluded - were not essential.

General statements made by individuals, both during the Philadelphia Convention and later, were in accord with the pronouncements of official groups. As the delegates were gathering in Philadelphia, William Pierce of Georgia wrote a letter to George Turner of South Carolina in which he compared Rome and America:

[T] he creation of Pra[e]tors, of Tribunes, of the Decemvirs etc. gave such an unsettled Spirit to the People, that they were never satisfied but when they were in pursuit of expedients to suit the various situations to which they were constantly shifting. Unless we can settle down into some permanent System very shortly, our condition will be as fickle and inconstant, as that of the Romans . . . . 130

In words that he more or less repeated on various other occasions, Wilson pointed out to the Pennsylvania ratifiers that the Constitutional Convention not only had to accommodate the varied situations of the existing states but also had to look ahead to

innumerable states yet unformed, and to myriads of citizens who in future ages shall inhabit the vast uncultivated regions of the continent.

128. Whether they composed the document is uncertain.

129. 2 M. FARRAND, supra note 1 , at 137 . Some confusion may arise because of a change in grammar since the eighteenth century. The words "unalterable, which" would today be written "unalterable that." More generally, although modern readers may conclude that the "essential principles" of the Constitution were "those provisions ... which ought to be accommodated to times and events," the meaning of this sentence was, in fact, different. It meant that the operations of government should not be clogged by rendering permanent and unalterable those provisions which ought to be accommodated to times and events. Any doubt about this should be resolved by the many discussions of permanency, discussed below, all of which support this article's interpretation of the statement in the Committee's draft.

130. Letter from William Pierce to George Turner, May 19, 1787, in M. Farrand, supra note 1, at 10 (Supp. 1987). 
The duties of that body, therefore, were not limited to local or partial considerations but to the formation of a plan commensurate with a great and valuable portion of the globe. ${ }^{131}$

He then went on to mention "the commercial scenes ... [that] will be exhibited on" the numerous rivers that "are intended to enrich the dominions of the United States."132 In the same speech, he said that they were selecting "that system of government, under which they would wish that they and their posterity should live."133 Some who became Anti-Federalists may have agreed or at least acquiesced in such sentiments. During the ratification controversy, Ellsworth wrote that Gerry had been willing during the Constitutional Convention "to concede every state interest that should be in the least incompatible with the most substantial and permanent system of general government ...."134 A contemporary evaluation of opinion in the summer of 1787 was given by Edward Carrington: "The prevailing impression as well in, as out of, Convention, is, that a federal Government adapted to the permanent circumstances of the Country, without respect to the habits of the day, be formed ...."135 A permanent constitution had to be adapted to permanent rather than temporary circumstances. ${ }^{136}$

131. Wilson in Pennsylvania Ratification Convention, Nov. 26, 1787, in 2 Documentary History supra note 1, at 340 (A.J. Dallas version).

132. Id. at 350 (T. Lloyd version). The two versions of Wilson's speech are relatively similar with respect to the passages cited in this article.

133. Id. at 353 (T. Lloyd version); see also id. at 342 (A.J. Dallas version).

134. Ellsworth, The Landholder, VI, The Connecticut Courant, Dec. 10, 1787, in P. ForD, EsSAYS, supra note 1, at 174.

135. Letter from Edward Carrington to Thomas Jefferson, June 9, 1787, in 3 M. FARRAND, supra note 1, at 38. Carrington wrote to Madison in support of a constitution "calculated for the permanent fitness, and not the momentary habits of the country . . . " Letter from Edward Carrington to James Madison, June 13, 1787, in 10 PAPERS OF JAMES MADISON 52. Carrington was not a member of the convention but did attempt to keep informed about it.

136. In the winter of 1787 , Rufus King expressed his hope that "a more permanent and vigorous government" would be established. Letter from Rufus King to E. Gerry, Feb. 11, 1787, in 1 The Life AND CorRespondence of Rufus King 202 (C. King ed. 1834). Pinckney said: "[T]his Constitution is not framed to answer temporary purposes. We hope it will last for ages - that it will be the perpetual protector of our rights and properties." Pinckney in South Carolina Ratification Convention, May 20, 1788, in 4 J. EllioT, supra note 1, at 335; see also Tweed in South Carolina Ratification Convention, May 20, 1788, in 4 J. EllioT, supra note 1, at 333. Franklin said that the Constitution was "a Transaction . . to exist in the Posterity of a great Nation . ..." Letter from Benjamin Franklin to the Editor of the Federal Gazette, Apr. 8, 1788, in 3 M. FARRAND, supra note 1, at 296-97. "A Briton" referred to "certain principles in government which our Magi hoped to render as durable as time." Gazette of the State of Georgia, Dec. 13, 1787, in 3 DocumentaRy History, supra note 1, at 255. Another writer hoped Americans would "be able peaceably to establish a government equal to the present exigencies of the country and made capable of anticipating the important changes which await it." To the Political Freethinkers of America, N.Y. Daily Advertizer, May 24, 1787, in 13 DocumENTARY History, supra note 1, at 115; see also Letter from William Short to James Madison, Dec. 21, 1787, in 10 PAPERS OF JAMES MADISON 342; Corbin in Va. Gen. Assembly, Oct. 25, 1787, in 8 DocumenTARY History, supra note 1, at 113; Americanus II, Va. Independent Chronicle, Dec. 19, 1787, 
Of course, there were exceptions. Respectful of the people's right to amend their constitution, and eager to provide assurance that amendment would be possible, some Federalists suggested that amendments could, among other things, adapt the Constitution to new circumstances. ${ }^{137}$ For these Federalists, the fact that adaptation would occur by amendment conferred a degree of legitimacy upon adaptation. ${ }^{138}$ More generally, Federalists recognized that adaptation by means of amendment might be necessary for constitutional provisions that had not been successfully drafted to avoid obsolescence. ${ }^{139} \mathrm{Nev}-$ ertheless, these Federalists were advocates of a permanent constitution. When acknowledging the possibility of, or need for, amendments

in 8 id. at 248; Civis Rusticus, Va. Independent Chronicle, Jan. 30, 1788, in 8 id. at 339; Pa. Gazette, Sept. 5, 1787, in 13 id. at 125; Z, Philadelphia Freeman's Journal, May 16, 1787, in 13 id. at 98; Philadelphia Independent Gazetteer, June 26, 1787, in 13 id. at 145; Maryland Journal, Sept. 28, 1787, in 13 id. at 263; cf. Federalism, Maryland Journal, Sept. 26, 1788 (letter to Goddard), in 2 FirST Federal Elections, supra note 1, at 121.

137. A few of Wilson's speeches hint at this view. See Wilson in Pennsylvania Ratification Convention, Nov. 26, 1787, in 1 WorKS OF J. WILSON supra note 52, at 544; Law Lectures, in 1 id. at 369; G. WooD, supra note 48, at 613-14. Shortly after ratification, Jonathan Jackson of Massachusetts discussed the possibility that "upon new exigencies or alterations of circumstances easy judicious reforms [would be] made." Letter from Jonathan Jackson to William Eustis, Dec. 1788, in 1 First Federal Elections, supra note 1, at 591. John Dickinson wrote somewhat ambiguously that "by a gradual progress, we may from time to time introduce every improvement in our constitution, that shall be suitable to our situation." Dickinson, Letters of Fabius, in P. FORD, supra note 1, at 209.

Some statements about amendment were not inconsistent with the view that amendment was a means of adapting to social change, but did not really address the issue. One of the more suggestive examples was Madison's 1789 proposal for a preamble to the Constitution, which contained the proposition " $[\mathrm{t}]$ hat the people have an indubitable, unalienable, and indefeasible right to reform or change their Government, whenever it be found adverse or inadequate to the purposes of its institution." Madison in House of Representatives Debate, June 8, 1789, in B. SchWartz, Bill of Rights, supra note 1, at 1026. Similarly, Pelatiah Webster wrote that the document "will always be liable to amendment, whenever any mischiefs or abuses appear in the government, which the Constitution in its present state, can't reach and correct." Webster, Reply to Brutus, Nov. 4, 1787, in P. FoRD, PAMPhlets, supra note 1, at 126.

Earlier, Thomas Pownall had written that the constitutions of some states contained " $a$ healing principle" if "there be any thing which in future times and circumstances might require a change." T. Pownall, A Memorial Addressed to the Sovereigns of America 53 (1783). The historian Gordon Wood cites this as a reference to amendment. G. Wood, supra note 48, at 614. Although Wood's interpretation is not necessarily incorrect, Pownall's example of the healing principle was "the establishment of a Census, and other means." This suggests the policy of avoiding obsolescence.

138. As has been seen, such ideas could also be apparent in Anti-Federalist arguments. See supra text at note 102.

139. For example, as will be seen, when it was pointed out that the apportionment ratio might one day become obsolete, Ellsworth suggested that future amendments would rectify the problem if it ever arose. See infra text accompanying note 163. Immediately after Ellsworth expressed this willingness to rely on amendments to adapt the Constitution to changing circumstances, other framers proposed a rule that would avoid the need for such adjustments. No one objected. See id. Ellsworth apparently believed that adaptation would be necessary for language that could not be made permanent. See also Convention Notes of James Madison, June 29, 1787, in 1 M. FARRAND, supra note 1, at 469; Convention Notes of Robert Yates, June 29, 1787, in id. at 475 . During ratification, Ellsworth was very articulate about the need for permanent language. See, e.g., infra note 163. 
to adapt the Constitution, they were merely acknowledging the theoretical and practical limitations to their goal of permanence.

A number of other Federalists, however, did question the possibility and desirability of a permanent constitution. According to "Publicola," even if the Constitution were

completely adapted to our present situation, so as to be unexceptionable to all, time would render it defective - Improvements in commerce and manufactures, in arts and sciences; an increase in population, and an alteration in manners, would render amendments to the new constitution necessary - nothing in this world can be permanent . . . ${ }^{140}$

Drawing on, among other things, the ideas of Montesquieu, Noah Webster condemned "perpetual constitutions" as unwarranted attempts to "control . . . future generations." ${ }^{141}$ Americans had as much right to perpetuate the jury as the English in Norman times had to bind their descendants to the ordeal. Webster heaped scorn on the advocates of "unchangeable constitutions." 142 He acknowledged, however, that he was broaching sentiments "repugnant to the principles received by my countrymen." 143 On this, he was correct. ${ }^{144}$

140. Publicola, State Gazette of N.C., March 20, 1788, in 16 Documentary HiSTORY, supra note 1, at 438 . For a similar perspective from a foreign observer, see Letter from Antoine de la Forest to Comte de Montmorin, Sept. 28, 1787, in 13 Documentary History, supra note 1 , at 259. Some statements were slightly ambiguous:

In proportion as knowledge and virtue prevail in our country, it will become as common for men to change and improve their governments, civil and ecclesiastical, as it is for men to alter and improve their houses, when the encrease of their families, or a change in their circumstances, make it necessary.

Pa. Gazette, Aug. 22, 1787, in 13 Documentary History, supra note 1, at 190. The assertion that improved knowledge of politics would permit improvement of the Constitution was a common sentiment, typically suggesting that the document would be made more perfect and therefore more likely to be permanent. This passage, however, suggests that the Constitution should be changed according to circumstances.

141. Webster, On Bills of Rights, 1 Aм. MAG. 13, 14 (Dec. 1787).

142. Webster, Government, 1 AM. MAG. 137, 139 (Feb. 1788).

143. Id. at 204, 209 (March 1788). Webster's essays are cited by G. WooD, supra note 48, at 377.

144. Although Webster argued that constitutions could not be made "unalterable," he acknowledged that he "would except the right of elections." Webster, Government, 1 AM. MAG. 137, 137 (Feb. 1788). Moreover, in his Examination, Webster advocated "irrevocable laws in every state, destroying and barring entailments," and he supported the Constitution. Webster, Examination, in P. FORD, PAMPHLETS, supra note 1, at 59.

A comparison between Webster and another extraordinary linguist, Sir William Jones, is irresistible. During the last half of the eighteenth century, on different sides of the globe, each of these men undertook the study of language. Subsequently, each wrote an important account of law that reflected and, perhaps, drew upon his earlier linguistic analysis.

In an astonishing variety of languages, Jones traced the relics of their common ancestry and thereby proved that there had been a single source for what have since become known as the Indo-European languages. Thereafter, he sought to elucidate the law of bailments from an eclectic variety of legal systems by looking for their shared elements - an approach that comported with some familiar ideas of natural law. In contrast, Webster became well known for pursuing another line of inquiry. Although he made arguments about language not unlike those of Jones, he also advocated that American spelling should conform to the pronunciation of contemporary Americans. Similarly, during ratification, he opposed the idea that future generations of Ameri- 
Two years later, in a letter from Paris, Jefferson similarly questioned "[w]hether one generation of men has a right to bind another" and concluded that "no society can make a perpetual constitution, or even a perpetual law." It was an idea, he wrote, that just then "comes into my head." 145 According to Jefferson, a challenge to the idea of a permanent constitution "seems never to have been started either on this or our side of the water." 146 On this, as has been seen, Jefferson was almost correct. ${ }^{147}$

\section{Nondiscretionary Provisions}

The Federalists' desire to establish constitutional provisions that would be both permanent and nondiscretionary — that would avoid obsolescence without simply giving discretion to the federal or state governments - can be illustrated by the debates concerning the second branch of the legislature, the first branch, and the western states.

When discussing the need for members of the second branch of the legislature to serve for extended terms, Madison gave a detailed account of America's changing social structure and its effect on American values and government. Pinckney had insisted that America did not and for a considerable time would not have the various ranks and extremes of wealth and poverty that so troubled Europe. ${ }^{148}$ Madison responded that "[i]n all civilized Countries the people fall into different classes . . . . There will be creditors \& debtors, farmers, merch[ants] \& manufacturers. There will be particularly the distinction of rich and poor. ... We cannot ... be regarded even at this time, as one homogeneous mass . ..." ${ }^{149}$ Moreover, the future held worse in store, and the Constitution had to accommodate this too:

In framing a system which we wish to last for ages, we sh[ould] not lose

cans should be constrained by a constitutional law no longer in accord with American society. For both Jones and Webster, their study of language may have contributed to their analyses of law, but whereas Jones examined the variety of language and law to discover what was common to all nations, Webster attempted to demonstrate the inevitability of variety - what was unique to each nation and time.

145. Letter from Thomas Jefferson to James Madison, Sept. 6, 1789, in 15 THE PAPERS OF ThOMAS JeFFERSON 392, 392, 395-96 (J. Boyd ed. 1958).

146. Id. at 392 . In late 1787 , Jefferson had approved of a "permanent form of government." Enclosure in letter of Dec. 31, 1787, in $12 \mathrm{id}$. at 478 (1955). Indeed, in 1788, Webster criticized Jefferson for his insistence on a constitution unalterable by an ordinary legislature.

147. The notion had a precedent not only in the writings of Webster but also those of Milton. Justifying Parliamentary sovereignty, Milton asked: [C]ould our forefathers bind us to any certain form of government more than we can bind our posterity?"' J. MILTON, BRIEF Notes ON Dr. Griffith's SERMON (1660), quoted in C. MCIlwaIN, supra note 64, at 94

148. Convention Notes of James Madison, June 25, 1787, in 1 M. FARRAND, supra note 1, at 397-404.

149. Convention Notes of James Madison, June 26, 1787, in 1 M. FARRAND, supra note 1, at 422 . 
sight of the changes which ages will produce. An increase of population will of necessity increase the proportion of those who will labour under all the hardships of life, \& secretly sigh for a more equal distribution of its blessings. These may in time outnumber those who are placed above the feelings of indigence. According to the equal laws of suffrage, the power will slide into the hands of the former. No agrarian attempts have yet been made in this Country, but symptoms of a leveling spirit, as we have understood, have sufficiently appeared in . . . certain quarters to give notice of the future danger. ${ }^{150}$

Madison feared that the growth of an indigent, laboring class would give rise to a demanding "leveling spirit" or egalitarianism. Therefore, when discussing the second branch, he advocated terms of a "considerable duration," which would, he thought, accommodate the dangers of egalitarianism better than frequent elections.

Sherman responded tartly that "[ $\mathrm{t}]$ he more permanency it has the worse if it be a bad Gov[ernment]," but he became more conciliatory. ${ }^{151}$ Although he said that frequent elections would "give permanency to the Government," he suggested that six- or four-year terms would be sufficient. ${ }^{152}$ Hamilton "concurred" with Madison's remarks and added some of his own. According to Hamilton, "[t]he difference of property is already great amongst us. Commerce and industry will still increase the disparity. Your government must meet this state of things, or combinations will in process of time, undermine your system."153 Madison and Hamilton held unusually sophisticated views on the future of American class structure and how the second branch of the legislature could accommodate it, but there was nothing unusual about their assumption that a permanent constitution was desirable. ${ }^{154}$

A similar interest in permanent, nondiscretionary structures may

150. Id. at $422-23$.

151. Id. at 423 (remarks of Sherman).

152. Id. at 423 .

153. Convention Notes of Robert Yates, June 26, 1787, in id. at 432. Madison's account is not inconsistent with this. Another example of Hamilton's anticipation of social change and its effect upon the legislative branch may be found in Federalist Number 60 . While addressing the possibility that a particular class of electors would come to dominate the legislature, Hamilton argued that the differences between inhabitants of different states would "occasion a material diversity of disposition in their representatives towards the different ranks and conditions in society." In presenting this argument he acknowledged that such differences probably would diminish with time: "[A]n intimate intercourse under the same government will promote a gradual assimilation" in some respects, "but not sufficiently, he thought, to eliminate such differences. The Federalist, supra note 2, No. 60 (Hamilton), at 404-05.

154. In the ratification debates, Federalists defended the terms of representatives and senators on the ground that they would require time to acquaint themselves with the information necessary for them to fulfill their duties. An example concerning representatives that is also interesting for its anticipation of change is Ames' comment in the Massachusetts Ratification Convention: "The time, I hope, will come, when this excellent country will furnish food, and freedom ... for fifty millions of happy people. Will any man say that the national business can 
be observed in the debates about the first branch, the House of Representatives. In particular, the problem of apportionment of representatives to that branch led the Convention to consider at length America's future population and territory. The solution of a ratio was attractive because of the common belief that the nation would require an increase in representatives as it advanced in population. ${ }^{155}$

After the Convention, in Federalist Number 55, Madison expressed his understanding of the ratio. Countering the claim that the initial sixty-five representatives was a dangerously small number, Madison said that he could not conceive there were then or in the near future would be sixty-five or a hundred men who would willingly betray the trust committed to them. He modestly added, however: "What change of circumstances[,] time[,] and a fuller population of our country may produce, requires a prophetic spirit to declare, which makes no part of my pretensions." ${ }^{156}$ Yet Madison did seek to anticipate at least the possibility of future developments and their effect on the Constitution. In the very next number of the Federalist, he explained the effect of the "changes of time" on the internal affairs of the states:

At present some of the states are little more than a society of husbandmen. Few of them have made much progress in those branches of industry, which give a variety and complexity to the affairs of a nation. These[,] however[,] will in all of them be the fruits of a more advanced population; and will require on the part of each state a fuller representation. The foresight of the Convention has accordingly taken care that the progress of population may be accompanied with a proper increase of the representative branch of the government. ${ }^{157}$

Madison's description of the development of society and of how government must keep pace with it sounds very much like an application of Scottish historical sociology in the novel context of an American constitution.

Some opponents of a ratio based on population attempted to have apportionment left to the discretion of the federal legislature. Morris reported on behalf of a committee appointed to consider apportionment that "as the present situation of the States may probably alter as well in point of wealth as in the number of their inhabitants, that the

be understood in one year?" Ames in Massachusetts Ratification Convention, Jan. 15, 1787, in 2 J. Elliot, supra note 1, at 10.

155. The Federalist, supra note 2, No. 84 (Hamilton), at 584; Hamilton in New York Ratification Convention, June 20-21, 1788, in 2 J. Elliot, supra note 1, at 238-39, 251; Ellsworth, The Landholder, VI, The Connecticut Courant, Dec. 10, 1787, in P. ForD, EsSAYS supra note 1, at 152; The Republican, To the People, The Connecticut Courant, Jan. 7, 1787, in 3 DOCUMENTARY HISTORY, supra note 1, at 530; Remarks of Randolph \& Wilson, in Convention Notes of James Madison, July 12, 1787, in 1 M. FARRAND, supra note 1, at 594-95.

156. The Federalist, supra note 2, No. 55 (Madison), at 376.

157. The Federalist, supra note 2, No. 56 (Madison), at 382. 
Legislature be authorized from time to time to augment ye. number of Representatives." 158 He later tried to justify this broad legislative discretion by questioning the possibility of finding a permanent rule: "If we can't agree on a rule that will be just at this time, how can we expect to find one that will be just in all times to come[?] Surely those who come after us will judge better of things present, than we can of things future." 159 The Convention, however, did not abandon the solution of a ratio. ${ }^{160}$

Yet some discretion was necessary. A ratio posed the danger that representatives might in the distant future become too numerous. During the Convention, Madison objected to a fixed ratio as a perpetual rule. "[I]f the Union sh[ould] be permanent," the future increase of population would "render the number of Representatives excessive." 161 His remarks prompted this colloquy:

Mr. G[orha]m. It is not to be supposed that the Gov[ernment] will last so long as to produce this effect. Can it be supposed that this vast Country including the Western territory will 150 years hence remain one nation?

Mr. Elseworth. If the Gov[ernment] should continue so long, alterations may be made in the Constitution in the manner proposed in a subsequent article. ${ }^{162}$

Although Ellsworth thought that the amendment process could be used to update the ratio if it should become obsolete in the distant future, Sherman and Madison suggested instead a rule that would be permanent - representation "not exceeding" one for every 40,000 and this was accepted without dissent. ${ }^{163}$ Toward the conclusion of 559 .

158. Convention Notes of James Madison, July 9, 1787, in 1 M. FARRAND, supra note 1, at

159. Convention Notes of James Madison, July 11, 1787, in 1 M. FARRAND, supra note 1, at 583. See also the committee report delivered by Morris in the Convention Notes of James Madison, July 9, 1787, in 1 id. at 559-60, and King's argument in the Convention Notes of James Madison, July 6, 1787, in 1 id. at 541. For Mason's views contra see The Convention Notes of James Madison, July 11, 1787, in $1 \mathrm{id}$. at 578.

160. See Convention Notes of James Madison, Aug. 8, 1787, in 1 M. FARRAND, supra note 1 , at $594-95$.

161. Convention Notes of James Madison, Aug. 8, 1787, in 2 id. at 221.

162. Id.

163. Id. Later, Ellsworth adopted the permanency argument: "[W]hen the whole [of America] is populated it will constitute a legislature unmanageable by its numbers. Convention foreseeing this danger, have so worded the article, that if the people should at any future time judge necessary, they may diminish the representation." Ellsworth, The Landholder, IV, The Connecticut Courant, Nov. 26, 1787, in P. ForD, EsSAYS, supra note 1, at 152.

The possibility that a ratio based on population might eventually lead to an excessive number of representatives was raised earlier by King as an argument for apportionment based on property: "[T] he Ratio of Representation proposed could not be safely fixed, since in a century \& a half our computed increase of population would carry the number of representatives to an enormous excess . . . " Convention Notes of James Madison, July 6, 1787, in 1 M. FARRAND, supra note 1 , at 541 . 
the Convention, the 40,000 was changed to 30,000 . In the Pennsylvania ratification convention, Wilson defended the "not-exceeding" formula: "[T]he present number of their inhabitants will be doubled in twenty-five years, and according to that progressive proportion, and the ratio of one member for thirty thousand inhabitants, the House of Representatives will, within a single century, consist of more than six hundred members." 164 An excessive number of legislators within a hundred years had to be avoided. ${ }^{165}$

The two branches of the legislature were not the only subjects that prompted discussion of how nondiscretionary provisions could be made permanent. The need to incorporate western states was a pressing issue in the late $1780 \mathrm{~s} .{ }^{166}$ It prompted thought about the shape of the United States in both the near and distant future and therefore gave rise to concern about the permanency of the Constitution's structure.

In objecting to provisions that would ensure eastern domination of the Union, Sherman argued that "there was no probability that the number of future States would exceed that of the Existing States" and that "[i]f the event should ever happen, it was too remote to be taken into consideration at this time." $167 \mathrm{He}$ continued, "Besides We are providing for our posterity, for our children \& our grand Children,

164. Wilson in Pennsylvania Ratification Convention, Nov. 20, 1787, in 2 J. Elliot, supra note 1, at 442; see also Coxe, An Examination, in P. FORD, PAMPHLETS, supra note 1, at 143.

165. The legislative discretion permitted by the apportionment clause was disliked by some Anti-Federalists. Madison and some "friends to the constitution" also favored amendment, because, in the view of Madison, "it should not be left in the discretion of the Government to diminish" apportionment below that initially provided for by the Constitution. Madison in House of Representatives Debate, June 8, 1789, in B. SchwARTZ, BILl of RightS, supra note 1, at 1032; see also id. at 1077-87. A bizarre (or perhaps satirical) editorial in a Pennsylvania newspaper criticized the apportionment clause both for not being based on a ratio (which in fact it was) and for not preventing an excessive number of representatives (which in fact it did). Nevertheless, the argument is of interest:

If we consider the vast extent and increasing population of the United States, it will appear that a representation upon this principle (though proper to begin with) cannot last very long. It must grow far too unwieldy for business and the Constitution must therefore be mended and patched with new work. Let your government be invariably fixed; so far, at least, as human foresight can go, and age will secure it respect and veneration from the multitude. In framing a government, we should consider a century to come as but a day, and leave the least possible for posterity to mend. Errors sanctified by long usage are not easily relinquished. Their age attaches the people and renders a reform difficult. There is even danger in reforming the errors of a government, but there is more in letting them along. Hence we ought to aim at PERMANENCY in every part of a constitution intended to endure.

Freeman's Journal, Sept. 26, 1787, in 2 DOCuMENTARY HISTORY, supra note 1, at 146.

166. In recent years, a number of historians have examined the influence of the western territories upon the political thought of late eighteenth-century Americans. Among these scholars is Professor Peter Onuf, who has argued that perceptions of the west influenced the development of republican thought in the 1780s. See Onuf, Liberty, Development, and Union: Visions of the West in the 1780s, 43 WM. \& MARY Q. 179 (1986).

167. Convention Notes of James Madison, July 14, 1787, in 2 M. FARRAND, supra note 1, at 3. 
who would be as likely to be citizens of new Western States, as of the old States. On this consideration alone, we ought to make no . . . discrimination [between western and eastern states]."168 Although Sherman said he was willing to discount a remote contingency, he said this as an argument for what he apparently conceived to be the permanent solution. Sherman knew in a very literal sense that "[w]e are providing for our posterity." 169

The framers and ratifiers had some glimpses of the vastness of the future United States. Mason argued for equal treatment of new states as the only way to prevent them from rebelling. He anticipated that they might "in time . . . be both more numerous $\&$ more wealthy than their Atlantic brethren," and he predicted that they would force Spain to give them access to the Pacific, which was "the natural outlet for their productions." 170 At the Pennsylvania ratifying convention, Wilson elaborated on one of his favorite themes:

$[\mathrm{T}]$ heir views could not be confined to a small or a single community, but were expanded to a great number of states .... Nor were even these the only objects to be comprehended within their deliberations. Numerous states yet unformed, myriads of the human race, who will inhabit regions hitherto uncultivated, were to be affected by the result of their proceedings. ${ }^{171}$

"We are representatives," he said, "not merely of the present age, but of future times; not merely of the territory along the seacoast, but of regions immensely extended westward. . . . I wish the honorable gentlemen would think not only of themselves, not only of the present age, but of others and of future times." 172 In sum, although the framers and ratifiers could not prognosticate the precise future of the American west, some of them attempted to discern its main features and construct constitutional structures that would accommodate it. ${ }^{173}$

168. Id.

169. Id. So too in the debate about the second branch, Sherman doubted the attractiveness of a permanent constitution if it were a bad constitution, but he apparently supported what was considered permanent language. See supra text at note 152.

170. "[T]hough Spain might for a time deprive them of the natural outlet for their productions, yet she will, because she must, finally yield to their demands." Convention Notes of James Madison, July 11, 1787, in 1 M. FARRAND, supra note 1, at 579.

171. 1 Works OF J. Wilson, supra note 52, at 526.

172. Wilson in Pennsylvania Ratification Convention, Dec. 4, 1787, in 2 Documentary History, supra note 1 , at $477-78$.

173. Among the other issues that prompted discussion of fixed constitutional rules and the danger of obsolescence was the question whether the states or the people should elect their legislators. Hamilton argued that the people should elect the first branch of the legislature, because, among other things, "the State Gov[ernments] might gradually dwindle into nothing. The system therefore sh[ould] not be engrafted on what might possibly fail." Convention Notes of James Madison, June 21, 1787, in I M. FARRAND, supra note 1, at 358-59. Later, Wilson insisted that the second branch also be elected by the people, giving as one of his reasons that, "[w]hen we are laying the foundation of a building, which is to last for ages, . . . it ought to be 


\section{Discretionary Provisions}

Although Federalists wished to establish the government upon nondiscretionary limitations and structures, they realized that in many instances nondiscretionary provisions could become obsolete. In such cases, therefore, they sought to achieve permanency by giving the federal government (and occasionally the states) broad discretion. Some examples of this approach, relating to the two branches of the legislature and the incorporation of western states, have already been examined. Whereas, however, the debates on the legislature and the western states chiefly concerned nondiscretionary language and touched upon discretionary solutions only incidentally, for many other subjects the surviving debates focused directly on discretion as a means of attaining permanence. Therefore, such subjects are examined together in this section. The examples discussed below - by no means the only examples - are drawn from the debates on compensation, qualifications of candidates, the time and place of elections, revenue, the military, and juries. These debates that concentrated on discretion demonstrate the willingness of Federalists to sacrifice constitutional rules or limitations for the sake of a permanent constitution. They thereby provide further evidence of the extent to which Federalists identified the Constitution as the place for rules that were permanent - that would not need to be adapted flexibly to circumstances.

Legislators' compensation was one of the issues that forced the

well laid." Convention Notes of Robert Yates, June 25, 1787, in 1 id. at 413; see also Convention Notes of James Madison, June 25, 1787, in 1 id. at 405.

On the power of each state in the second branch, Wilson argued:

[T] he rule of suffrage ought on every principle to be the same in the $2 \mathrm{~d}$. as in the 1st. branch. If the Government be not laid on this foundation, it can be neither solid nor lasting, any other principle will be local, confined \& temporary. This will expand with the expansion, and grow with the growth of the U. States.

Convention Notes of James Madison, June 30, 1787, in 1 id. at 483.

When urging that the Constitution should restrict suffrage for the House of Representatives to freeholders, some framers made arguments based on the changes they anticipated in America's social structure. Dickinson sought "the restriction of the right to [freeholders] as a necessary defence ag[ainst] the dangerous influence of those multitudes without property \& without principle, with which our Country like all others, will in time abound." Convention Notes of James Madison, Aug. 7, 1787, in 2 id. at 202. As a debate developed about the exclusion of nonfreeholders, including merchants and industrial employees, Dickinson's point was pursued. According to Morris, "We should not confine our attention to the present moment. The time is not distant when this Country will abound with mechanics \& manufacturers who will receive their bread from their employers. Will such men be the secure \& faithful Guardians of liberty?" 2 id. at 202. Madison also took up the theme. "In future times a great majority of the people will not only be without landed, but any other sort of, property." The people without property would, said Madison, become either a threat to property and liberty or, more probably, easily bribed instruments of the opulent and ambitious. 1 id. at 203-04. See also J. MADISON, Observations on Jefferson's Draft of a Constitution for Virginia, in 11 PAPERS OF JAMES MADISON 281, 287-88 (1977). 
framers to turn to federal legislative discretion as the only permanent solution. As with judges' compensation, the danger of inflation was well understood and would not permit an amount to be fixed in the Constitution. Another possible solution was state control of federal salaries. This appealed to some but was rejected. Wilson pointed out that conceivably "the states may become unfederal, and they may then shake the national government." 174 Madison seconded: "Our attention is too much confined to the present moment, when our regulations are intended to be perpetual." ${ }^{175}$ Like fixed wages, state control of salaries was inconsistent with permanence. Madison expressed hopes of fixing compensation in the Constitution "by taking a standard which w[oul]d not vary with circumstances." 176 His proposal for such a standard - that salaries be tied to the value of a certain amount of wheat - was not, however, sufficiently permanent. ${ }^{177}$ As Morris presciently observed in a similar debate about judges' salaries:

The value of money may not only alter but the State of Society may alter. In this event [the value of] the same quantity of wheat . . . would not be the same compensation. The Amount of salaries must always be regulated by the manners \& the style of living in a Country. ${ }^{178}$

Thus, the framers were left with the prospect of giving federal legisla377.

174. Convention Notes of Robert Yates, June 22, 1787, in 1 M. FARRAND, supra note 1, at

175. Id. at 378 .

176. Convention Notes of James Madison, June 22, 1787, in 1 M. FARRAND, supra note 1, at 373. In the Virginia Ratification Convention, Madison said:

I will acknowledge that their compensations, if practicable, should be fixed in the Constitution itself, so as not to be dependent on Congress itself, or on the state legislatures. The various vicissitudes, or rather the gradual diminution, of the value of all coins and circulating medium, is one reason against ascertaining them immutably; as what may be now an adequate compensation, might, by the progressive reduction of the value of our circulating medium, be extremely inadequate at a period not far distant.

3 J. Elliot, supra note 1, at 369; see also id. at 372. Note that Virginia and some other states had, at various times during their histories, required certain payments to be made in specified commodities, such as tobacco.

177. For his proposal, see Convention Notes of James Madison, June 12, 1787, in 1 M. FARRAND, supra note 1, at 215-16. For a slightly different but related approach, see Ellsworth's views, in Convention Notes of James Madison, Aug. 14, 1787, in 2 id. at 292.

The June 22 debate about whether a fixed standard could be formulated was left unresolved, the Convention agreeing "that the practicability of fixing the compensation should be considered hereafter in forming the details." Convention Notes of James Madison, June 22, 1787, in 1 id. at 374-75.

178. Convention Notes of James Madison, July 18, 1787, in 2 M. FARRAND, supra note 1, at 45. Morris made this remark in response to Madison's suggestion that " $[t]$ he variations in the value of money, may be guarded ag[ainst] by taking for a standard wheat or some other thing of permanent value." Id. Like Morris, Hamilton later argued that "fluctuations in the value of money, and in the state of society, rendered a fixed rate of compensation in the constitution inadmissable." The Federalist, supra note 2, No. 79 (Hamilton), at 531-32; see also Mason's remarks in Convention Notes of James Madison, Aug. 27, 1787, in 2 M. FARRAND, supra note 1, at 429; Madison in Virginia Ratification Convention, June 20, 1788, in 3 id. at 332; McKean in Pennsylvania Ratification Convention, Dec. 10, 1787, in 2 DocumentaRY History, supra note 1 , at 540-41, 544-45. 
tors discretion over their own compensation. ${ }^{179}$ That the framers accepted this unattractive solution reveals how very much they considered permanency an essential attribute of a constitution. What could not be permanent could not be included. ${ }^{180}$

The acceptance of legislative discretion for the sake of constitutional permanency is also apparent in the discussions of legislative elections. Wilson opposed a disqualification of candidates who were debtors on the ground that in the future, as during the Revolutionary War, the government might need to borrow funds, and persons who patriotically raised money for the government by borrowing from the public should not be excluded from the legislature. "We should consider," he warned, "that we are providing a Constitution for future generations, and not merely for the peculiar circumstances of the moment." 181 In a later discussion, Ellsworth argued that " $[t]$ he different circumstances of different parts of the U.S. and the probable difference between the present and future circumstances of the whole, render it improper to have either uniform or fixed qualifications." 182 Ellsworth's desire to "leave this matter to . . . Legislative discretion" elicited a response from Madison that such discretion might be abused and, further, that qualifications of the electors and the elected were "fundamental articles in a Republican Gov[ernmen]t and ought to be fixed by the Constitution" - a reminder that Federalists retained some traditional expectations about what matters had to be included in the document. ${ }^{183}$

With respect to the times, places, and manner of elections, the framers left discretion in the states and Congress. In the Virginia ratifying convention, Madison explained that exclusive state regulation of elections would destroy the federal government, and that the times, places, and manner of elections "could not be fixed in the Constitution

179. For Federalist assertions and explanations of this solution (or variants thereof), see Dickinson in Convention Notes of James Madison, Aug. 14, 1787, in 2 M. FARRAND, supra note 1, at 292; Madison in Virginia Ratification Convention, June 14, 1788, in 3 id. at 313-14. Note that the framers were even cautious enough to settle upon language that refers to "compensation" rather then "salaries."

180. Concerning the $\$ 20$ value-in-controversy requirement of the seventh amendment, see infra text accompanying notes 213-15.

181. Convention Notes of James Madison, July 26, 1787, in 2 M. FARRAND, supra note 1, at 125. Langdon expressly agreed with "the reasons given by $\mathrm{Mr}$ Wilson." 2 id. at 125 .

182. He continued, "[W]hat may be accommodated to the existing State of things among us, may be very inconvenient in some future state of them." Convention Notes of James Madison, Aug. 10, 1787, in 2 id. at 249.

183. Id. at 249-50. Similarly, just several days earlier, Madison had opposed a discretionary provision on suffrage for the House, since "suffrage is certainly one of the fundamental articles of republican Government, and ought not be left to be regulated by the Legislature." Convention Notes of James Madison, Aug. 7, 1787, in id. at 203. 
without involving great inconveniences. They could then have no authority to adjust the regulation to the changes of circumstances. The question then is, whether it ought to be fixed unalterably in the state governments, or subject to the control of the general government." 184 The language concerning legislative elections had to be able to accommodate "changes of circumstances." In the ratification debates, other Federalists also raised such arguments, including the suggestion that federal control was necessary because war against foreign invaders or among the states might interrupt state governments. ${ }^{185}$

The federal government's power to raise money by taxation or borrowing prompted very extensive discussions of the Constitution's permanency, particularly by those, such as Madison and Hamilton, who thought about the appropriateness of restrictions on federal revenues.

Federalists sought powers of taxation that would be adequate notwithstanding changes in the economy. Dickinson argued: "The power of taxing exports may be inconvenient at present; but it must be of dangerous consequences to prohibit it with respect to all articles and for ever."186 Madison said further: "As we ought to be governed by national and permanent views, it is a sufficient argument for giving ye power over exports that a tax, tho' it may not be expedient at present, may be so hereafter." 187 Although other framers disputed the

184. Madison in Virginia Ratification Convention, June 14, 1788, in 3 J. ElLIOT, supra note 1 , at 408 .

185. The Federalist, supra note 2, No. 59 (Hamilton), at 398; No. 61 (Hamilton), at 414; Letter from New York, Connecticut Journal, Oct. 24, 1787, in 3 DocuMENTARY HisTORY, supra note 1, at 384-85; Ames in Massachusetts Ratification Convention, Jan. 21, 1788, in 2 J. ElliOT, supra note 1, at 48; Gov. Johnston in North Carolina Ratification Convention, July 25, 1788, in 4 id. at 50. For the war argument, see Sumner in Massachusetts Ratification Convention, Jan. 17, 1788, in 2 id. at 32; Iredell in North Carolina Ratification Convention, July 25, 1788, in 4 id. at 53-54. In a letter to Theophilus Parsons, George Cabot worried that if Anti-Federalists

should insist that it might and ought to have been fixed immovably in the Constitution, it will be difficult to answer them. For I cannot see why a rule might not have been made of a kind that should answer that description, and yet accommodate itself to the changes in population, \&c....

Letter from George Cabot to Theophilus Parsons, Feb. 28, 1788, in 16 Documentary HisTORY, supra note 1 , at 249 . In the Pennsylvania ratification convention, Wilson defended the legislative discretion by looking to future political tactics:

Another thing may possibly happen, I don't say it will; but we were obliged to guard even against possibilities, as well as probabilities. A legislature may be willing to make the necessary regulations, yet the minority of that legislature may, by absenting themselves, break up the house and prevent the execution of the intention of the majority. I have supposed the case, that some state governments may make no regulations at all.

Wilson in Pennsylvania Ratification Convention, Nov. 28, 1787, in 2 id. at 403 . Wilson was being either sarcastic or excessively tactful, for the departure of a minority to prevent a quorum was a maneuver with which Pennsylvanians were all too familiar.

186. Convention Notes of James Madison, Aug. 21, 1787, in 2 M. FARRAND, supra note 1, at 361. He continued by saying that "[h]e thought it would be better to except particular articles from the power." $I d$.

187. Id.; see also Dickinson's comments, id. Fitzsimmons was "for giving a power of laying 
question of taxes on exports, they did not challenge the need to anticipate future circumstances.

In the Federalist, Madison further developed the taxation issue by discussing imports: "[T] he extent of revenue drawn from foreign commerce, must vary with the variations both in the extent and the kind of imports . . ." 188 It was this rather than the progress of population that would determine the appropriateness of taxes on imports:

As soon as domestic manufactures are begun by the hands not called for by agriculture, the imported manufactures will decrease as the numbers of people increase. In a more remote stage, the imports may consist in a considerable part of raw materials which will be wrought into articles for exportation .... A system of Government, meant for duration, ought to contemplate these revolutions, and be able to accommodate itself to them. ${ }^{189}$

The Constitution's provisions for revenue had to provide for "revolutions" or changes in the American economy, even those that would occur in "a more remote stage." 190 As a result, those provisions had to permit wide discretion rather than fix particular means of raising revenue. Similar views were expressed by Hamilton and Livingston in the New York ratification convention. ${ }^{191}$

Not only the sources and methods of taxation but also the unpre-

the tax when a proper time may call for it - This would certainly be the case when America should become a manufacturing country." Id. at 362 .

188. The Federalist, supra note 2, No. 41 (Madison), at 276.

189. Id. at 276-77.

190. In the Virginia Ratification Convention, Madison said: "Although the impost may even increase during the term of twenty-five years, yet when we are preparing a government for perpetuity, we ought to found it on permanent principles, and not on those of a temporary nature." Madison in Virginia Ratification Convention, June 12, 1788, in 3 J. ElLIOT, supra note 1, at 310; see also id. at 309.

191. In New York, Hamilton argued about the "objects of revenue":

To ascertain this division of objects [of revenue] is the proper business of legislation: it would be absurd to fix it in the Constitution, both because it would be too extensive and intricate, and because alteration of circumstances must render a change of the division indispensable. Constitutions should consist only of general provisions: the reason is, that they must necessarily be permanent, and that they cannot calculate for the possible change of things [i.e., prognosticate future events].

Hamilton in New York Ratification Convention, June 28, 1788, in 2 id. at 364; see also id. at 363, 369. Livingston argued "that, at a future period, this would be a manufacturing country .... But the gentleman [Melancton Smith], in answer to this, says we ought not to look forward to a future period. What, then, must be this government of a day? It is the third time we have been making a government, and God grant it may be the last." Livingston in New York Ratification Convention, June 30,1788, in id. at 386; see also id. at 341. For Melancton Smith's comment, see text accompanying infra note 219.

The Constitution's prohibition of direct taxes not in proportion to the census encouraged dependence upon indirect taxes, and therefore Hamilton undertook to show that these "consumption" taxes "must always constitute the chief part of the revenue raised in this country." Direct taxes, particularly those on land, required evaluations, and "in a country imperfectly settled and progressive in improvement, the difficulties are increased almost to impracticability." The Federalist, supra note 2, No. 21 (Hamilton), at 134-35. Thus, direct taxes would hardly be feasible, let alone desirable, for a long time. 
dictability of the need for revenue required broad federal discretion. Hamilton wrote:

[W] are not to confine our view to the present period, but to look forward to remote futurity. Constitutions of civil Government are not to be framed upon a calculation of existing exigencies; but upon a combination of these, with the probable exigencies of ages .... There ought to be a CAPACITY to provide for future contingencies, as they may happen; and, as these are illimitable in their nature, it is impossible safely to limit that capacity. ${ }^{192}$

He pursued this theme to the principle that "[i]n framing a Government for posterity as well as ourselves, we ought in those provisions which are designed to be permanent, to calculate not on temporary, but on permanent causes of expence." 193 Other Federalists advocated similar views, albeit less elegantly and usually in connection with their anticipation of future wars. ${ }^{194}$

A few Anti-Federalists discussed the possibility of war in their arguments for allowing the federal government to issue bills of credit. When the Constitutional Convention considered a proposal to eliminate language authorizing the federal government to "emit bills on the credit of the U. States," Mason - who became an Anti-Federalist expressed doubts about the motion. "Though he had a mortal hatred to paper money, yet as he could not foresee all emergenc[i]es, he was unwilling to tie the hands of the Legislature. He observed that the late war could not have been carried on, had such a prohibition existed." 195 Gorham promptly assured Mason that "The power as far as

192. The Federalist, supra note 2, No. 34 (Hamilton), at 210-11.

193. The Federalist, supra note 2, No. 34 (Hamilton), at 213-14.

194. For a general statement, see Sedgwick in House of Representatives Debate, Aug. 22, 1789, in B. SCHWARTZ, BILl of RIGHTS, supra note 1, at 1137. Other general statements were made together with more specific arguments about war. See THE FEDERALIST, supra note 2, No. 23 (Hamilton), at 147; No. 36 (Hamilton), at 229; Hamilton in New York Ratification Convention, June 27, 1788, in 2 J. Elliot, supra note 1, at 351, 364; Livingston in New York Ratification Convention, June 27, 1788, in id. at 334, 343 ("a constitution should be calculated for all circumstances"); Gore in Massachusetts Ratification Convention, Jan. 22, 1788, in id. at 66; Madison in Virginia Ratification Convention, June 16, 1788, in 3 id. at 95-96, 249; Letter from Samuel H. Parsons to William Cushing, Jan. 11, 1788, in 3 Documentary History, supra note 1, at 570; Randolph in Virginia Ratification Convention, June 7, 1788, in 3 J. ElLIOT, supra note 1 , at $127-28$.

Other comments concerning taxation included Madison's response to a suggestion that executions levied by federal officers might interfere with those levied by state officers. Madison expostulated: "Is it not in the power of the general government to employ the state officers? Is nothing to be left to future legislation, or must every thing be immutably fixed in the Constitution?" Madison in Virginia Ratification Convention, June 12, 1788, in id. at 306. See also [Webster], America, N.Y. Daily Advertiser, Dec. 31, 1787, in 15 DocumentARY History, supra note 1 , at 198 .

195. Convention Notes of James Madison, Aug. 16, 1787, in 2 M. FARRAND, supra note 1, at 308-09. 
it will be necessary or safe, is involved in that of borrowing." 196 Thereafter, it was another future Anti-Federalist, Luther Martin, who pursued Mason's argument: "[I]t was impossible to look forward into futurity so far as to decide, that events might not happen, that should render the exercise of such a power absolutely necessary . ..."197 Martin doubted whether, "if a war should take place, it would be possible for this country to defend itself, without having recourse to paper credit. . .." 198 One did not have to be a Federalist to argue against constitutional restrictions that might become obsolete.

Similarly, broad military powers, including the power to raise a standing army, were required by the possibility of foreign invasions and other conflict. ${ }^{199}$ David Epstein has shown that the Federalist justified the Federal government's military authority as well as its right to raise revenues on the ground that unanticipated and unforeseeable exigencies might arise. 200 The Federalist was not alone. Among others, Massachusetts's Bowdoin argued that the military power had to be "according as circumstances or exigencies may require": "[A]s human foresight cannot extend to many of them, and all of them are in the womb of futurity, the quantum of the power cannot be estimated." 201 The Constitution had to allow extensive military powers, according to Duane of New York, since "the necessity . . . might in future exist, of maintaining large armies and navies . . .,"202

196. Id. Gorham's view was shared by Madison. See id. at 310 n.*

197. Martin, Genuine Information, in 3 M. FARRAND, supra note 1, at 206.

198. Id. Note that some of Martin's assertions about what he said in the Convention were disputed by Ellsworth in The Landholder, X, The Maryland Journal, Feb. 29, 1788, in P. ForD, ESSAYS, supra note 1, at 182.

199. Shay's Rebellion had drawn attention to the danger of insurrection. See, e.g., Madison in Virginia Ratification Convention, June 14, 1788, in $3 \mathrm{~J}$. ElliOT, supra note 1, at 425; Iredell in North Carolina Ratification Convention, July 26, 1788, in 4 id. at 96; Ellsworth, The Landholder, $V$, The Connecticut Courant, Dec. 3, 1787 in P. ForD, EsSAYS, supra note 1, at 157. See also the guarantee clause, U.S. CoNST. art. IV, $\S 4$, and the habeas corpus clause, U.S. ConST. art. I, $\S 9$, cl. 2.

200. D. Epstein, The Political Theory of the Federalist 21, 41, 45, 46, 47 (1984).

201. Bowdoin in Massachusetts Ratification Convention, Jan. 23, 1788, in 2 J. ElLIOT, supra note 1, at 84-85; see also Marshall in Virginia Ratification Convention, June 10, 1788, in 3 id. at 236; Madison in Virginia Ratification Convention, June 11, 1788, in id. at 248-49; Innes in Virginia Ratification Convention, June 25, 1788, in id. at 635. In the South, a fear of slave rebellions figured in arguments about the military. See, e.g., Randolph in Virginia Ratification Convention, June 9,1788 , in id. at 192.

202. Duane in New York Ratification Convention, July 1, 1788, in 2 id. at 379. Roger Sherman wrote:

Perhaps a provision that they should never raise troops in time of peace, might at some period embarrass the public concerns and endanger the liberties of the people. It is possible that in the infinite variety of events, it might become improper strictly to adhere to any one provision that has ever been proposed to be stipulated.

Sherman, Letters of a Countryman, in P. FORD, ESSAYS, supra note 1, at 222; see also Iredell in North Carolina Ratification Convention, July 26, 1788, in 4 J. ElLIOT, supra note 1, at 96; Iredell, Answer to Mr. Mason's Objections to the New Constitution, in P. Ford, PampHLETS, 
Melancton Smith responded to the discussion of a navy that "it was our duty to calculate for the present period, and not attempt to provide for the contingencies of two or three centuries to come." ${ }^{203}$ More commonly, Anti-Federalists disputed the likelihood of invasion and noted the dangers of an army or the Constitution's version of the militia. ${ }^{204}$

As James Stoner has argued, the need to permit adaptation to circumstances required discretionary congressional power over the judiciary and its jurisdiction. ${ }^{205}$ Among the arguments made by Federalists for broad congressional discretion over the establishment of courts was that it was "exceedingly inconvenient, to fix the arrangement in the Constitution itself, and not leave it to laws which may be changed according to circumstances." 206 Mason "thought many circumstances might arise not now to be foreseen, which might render

supra note 1, at 365; Civis Rusticus, Va. Independent Chronicle, Jan. 30, 1788, in 8 DocumeNTARY HISTORY, supra note 1, at 338; Letter from George Nicholas, Feb. 16, 1788, in id. at 370; A Citizen of Philadelphia, Remarks on the Address of Sixteen Members, Oct. 18, 1787, in 13 id. at 302 .

203. Smith in New York Ratification Convention, July 1, 1788, in 2 J. Elliot, supra note 1, at 381 .

204. See, e.g., Mason in Virginia Ratification Convention, June 14, 1788, in 3 id. at 425-26 (arguing that social change would have a dangerous effect on the composition of the militia); Tyler in Virginia Ratification Convention, June 25, 1788, in id. at 640.

In New York, Morris commented that "[t]he gentlemen, in all their zeal for liberty, do not seem to see the danger to be apprehended from foreign power . . . "Morris in New York Ratification Convention, June 24, 1788, in 2 id. at 297; see also Ellsworth, The Landholder, $V$, The Connecticut Courant, Dec. 3, 1787, in P. Ford, Essays, supra note 1, at 157.

205. James Stoner has suggested that the "ambiguity in the text of the Constitution" may have been due in part to a recognition that the judiciary and its jurisdiction might have to change. Therefore, such matters were left to "legislative adjustment rather than constitutional principle." Stoner, Constitutionalism and Judging in the Federalist, in Saving the RevoluTION 203, 206 (C. Kesler ed. 1987). If Stoner meant "grant of discretion" rather than "ambiguity," this article is in accord with his conclusion. Of course, article III contains ambiguities, some of which probably were the consequence of a stalemate and compromise. The framers and ratifiers, however, argued for legislative discretion rather than ambiguity as means of accommodating changing circumstances.

206. Pendleton in Virginia Ratification Convention, June 18, 1788, in 3 J. ElLiot, supra note 1, at 517; see also Letter from Edmund Pendleton to R.H. Lee, June 14, 1788, in 2 THE LeTTERS AND PAPERS OF EdMund PENDleton 535; Sherman, The Letters of "A Citizen of New Haven," in P. FORD, EsSAYS, supra note 1, at 235, 241. One writer asked, "Can you expect that the number of courts and the times and places of holding them through all future ages should be ascertained?" An Independent Freeholder, Winchester Va. Gazette, Jan. 18, 1788, in 8 DocuMENTARY HISTORY, supra note 1, at 312. When commenting on the judiciary in Jefferson's draft of a constitution for Virginia, Madison wrote:

Much detail ought to [be] avoided in the constitutional regulation of this department, that there may be room for changes which may be demanded by the progressive changes in the state of our population. It is at least doubtful whether the number of Courts, the number of Judges, or even the boundaries of Jurisdiction ought to be made unalterable but by a revisal of the Constitution.

Letter From James Madison to John Brown, in 11 The PAPERs of JAMEs MAdison 290 (1977). Later, in 1802, Morris took a similar position. Remarks of G. Morris in Senate, Jan. 14, 1802, in 3 M. FARRAND, supra note 1, at 392-93. 
such a power absolutely necessary."207 Similarly, questions of jurisdiction were largely left to Congress. ${ }^{208}$

Of course, as is well known, article III's broad grant of discretion was in part a product of compromise, but this, like other compromises in the Constitution, was not inconsistent with what has been said about permanence. In most instances, compromises in the drafting of the Constitution apparently led to results Federalists considered compatible with their desire for a lasting document. Compromises that led to increased federal discretion were particularly likely to accommodate Federalist concerns about permanence. In article III, for example, those who sought to require establishment of at least some, albeit unspecified, lower federal courts compromised and left lower courts entirely to the discretion of Congress - a result perfectly consistent with the goal of avoiding obsolescence.

Concerns about permanence led even to the creation of federal discretion at the expense of rights. This appears to have been the justification for the power to suspend habeas corpus. ${ }^{209}$ It clearly was one of the several arguments for the Constitution's omission of the right to a jury in civil cases. As a result of the complexity of the subject and the different practices of the various states, it was difficult enough to formulate a rule describing current jury rights in civil cases. The possibility of changes in circumstances posed still further problems. Hamilton, it will be recalled, believed that "the changes which are continually happening in the affairs of society may render a different mode of determining questions of property preferable in many cases in which that mode of trial now prevails." 210 Iredell argued:

there is a material difference between an article fixed in the Constitution, and a regulation by law. An article in the Constitution, however inconvenient it may prove by experience, can only be altered by altering the Constitution itself, which manifestly is a thing that ought not be done often. When regulated by law, it can easily be occasionally altered so as best to suit the conveniences of the people. ${ }^{211}$ 46.

207. Convention Notes of James Madison, July 18, 1787, in 2 M. FARRAND, supra note 1, at

208. See Wilson's Lectures, 2 Works of J. WILson, supra note 52, at 151-52; Sherman, Letters of Citizen of New Haven, in P. FORD, EsSAYS, supra note 1, at 241; see also supra note 206.

209. See Letter from James Madison to Thomas Jefferson, Oct. 17, 1788, in 11 PAPERS OF JAMES MADISON 299.

210. The Federalist, supra note 2, No. 83 (Hamilton), at 573. For a larger quotation from this passage, see supra text accompanying note 2 .

211. Iredell in North Carolina Ratification Convention, July 28, 1788, in 4 J. Elliot, supra note 1, at 144-45; see also Iredell in North Carolina Ratification Convention, July 29, 1788, in id. at 165-66; Maclaine in North Carolina Ratification Convention, July 28, 1789, in id. at 151. Shortly after these statements about juries, Governor Johnston used similar language to discuss 
Congressional discretion was necessary to avoid a constitutional rule that would become obsolete. As Madison said, the jury in civil cases "must be . . . left to the discretion of the legislature to modify it according to circumstances." 212

By 1789, however, only two years later, Madison and many other Federalists had come to accept a constitutional right to a jury in civil cases. Madison introduced in the House of Representatives not only a proposal for such a right but also what became the seventh amendment's twenty-dollar value-in-controversy restriction. ${ }^{213}$ Nevertheless, it should not be thought that Madison or other Federalists had become less desirous of a permanent Constitution. By late 1788 and 1789 , many Federalists, including Madison, were arguing that amendments would serve a useful political purpose without causing serious harm. As Madison explained when introducing his amendments to the House, they would

be practicable ... to obviate the objection [to the Constitution], so far as to satisfy the public mind that their liberties will be perpetual, and this without endangering any part of the constitution, which is considered as essential to the existence of the Government by those who promoted its adoption. ${ }^{214}$

Given his earlier comments about juries and about the changing value of money, Madison must have been aware that he was establishing in the Constitution something that was more properly a matter for legislation, but he apparently did not believe the inflexibility of what became the seventh amendment would endanger the continued existence of the federal government.

The seventh amendment is an example of a compromise that, unlike article III, probably seemed as if it would become at least partly obsolete. Madison and other Federalists, however, were content with this sort of compromise. Although the twenty-dollar requirement would become trivial through inflation, and the right to a jury in civil cases might become inappropriate in some instances, these types of

the supremacy clause. Johnston in North Carolina Ratification Convention, July 29, 1788, in id. at $187-88$.

212. Madison in Virginia Ratification Convention, June 20, 1788, in 3 id. at 537. Timothy Pickering wrote:

So if the Convention had positively fixed a trial by jury in all the civil cases . . . it might have been found as highly inconvenient in practice as the case above stated; but being fixed by the constitution, the inconvenience must be endured ... until the Constitution itself should be altered.

Letter from Timothy Pickering to Charles Tillinghast, Dec. 24, 1787, in 14 DocumentaRY History, supra note 1, at 205.

213. U.S. CONST. amend. VII. Initially, the restriction concerned appeals.

214. House of Representatives Debate, June 8, 1789, in 2 B. Schwartz, Bill of Rights, supra note 1, at 1025-26. 
obsolescence apparently were considered inconvenient rather than dangerous. Federalists could be satisfied with compromises that would produce obsolescence, if the ensuing difficulties were relatively minor. ${ }^{215}$

Thus, notwithstanding the occasional compromise, Federalists thought of constitutional law as permanent, and therefore they accepted discretion in a host of provisions. ${ }^{216}$ Their repeated sacrifice of constitutional limitations - even with respect to matters for which they considered discretion otherwise undesirable - illustrates how much Federalists desired to avoid obsolescence.

\section{Anti-Federalists on the Avoidance of Obsolescence}

Although espoused chiefly by Federalists, the necessity of avoiding obsolescence met with little criticism from Anti-Federalists. AntiFederalists could not easily dispute the Federalist insistence upon a constitution that would be permanent and able to survive.

Of course, some disapproved of the Federalists' concern about obsolescence. In addition to those Anti-Federalists who directly rejected the goal of permanence, ${ }^{217}$ a number of Anti-Federalists, like Harrison and Grayson, more cautiously suggested that America was not yet ready for a strong federal government, even if one day it might be. ${ }^{218}$ They questioned whether the Constitution should create a powerful federal government in anticipation of circumstances that had not yet occurred and could not be predicted. As mentioned above, Melancton

215. Compromise may have been particularly necessary and acceptable in connection with the Bill of Rights. Political circumstances made the amendments necessary, and the effects of such potential obsolescence as was apparent in the amendments probably did not seem very great.

216. The framers deliberately left many matters to the discretion of the federal and state governments. Some examples have already been given, including the compensation of legislators and judges, qualifications of candidates, the time and place of elections, revenue, the military, and juries. Other subjects that prompted discussion of permanence included commerce, about which Rutledge said: "As we are laying the foundation for a great empire, we ought to take a permanent view of the subject and not look at the present moment only." Convention Notes of James Madison, August 29, 1787, in 2 M. FARrand, supra note 1, at 452 . On appeals to the Supreme Court, see Webster, Examination, in P. Ford, PAMPhlets, supra note 1, at 53-54. On the executive, see Roger Sherman in Convention Notes of James Madison, June 1, 1787, in 1 M. FARRAND, supra note 1, at 65; and Charles Pinckney in the South Carolina House of Representatives, Jan. 16, 1788, in 3 id. at 249. On the naturalization provision, see Hamilton in The Convention Notes of James Madison, Aug. 13, 1787, in 2 id. at 268. On the necessary and proper clause, see Iredell, Answer to Mr. Mason's Objections to the New Constitution, in P. ForD, PAMPHLETS, supra note 1, at 356. On the Bill of Right's exclusion of a right not to be compelled to bear arms, see Benson in the House of Representatives, Aug. 17, 1789, in 2 B. SCHWARTZ, Bill of Rights, supra note 1, at 1109. On other rights, see America [Webster], N.Y. Daily Advertiser, Dec. 31,1787 , in 15 DocumentaRY HiSTORY, supra note 1, at 199. On the common law, see supra note 4.

217. See supra text accompanying notes 97-101.

218. See supra text accompanying note 102. 
Smith had a somewhat similar objection to the suggestion that the United States should have a navy. He believed that

it was our duty to calculate for the present period, and not attempt to provide for the contingencies of two or three centuries to come. In time, events might take place which no human wisdom could foresee, and which might totally defeat and render useless these provisions. He insisted that the present state of the country alone ought to be considered. In three or four hundred years, its population might amount to a hundred millions: at this period, two or three great empires might be established, totally different from our own. ${ }^{219}$

Reacting to the broad federal powers that the framers had accepted in order to accommodate future developments, Smith and some other Anti-Federalists argued that the Constitution should be adapted to present circumstances. According to the "Federal Farmer":

[W] ought to give power to the union, so far only as experience and present circumstances shall direct, with a reasonable regard to time to come. Should future circumstances, contrary to our expectations, require that further powers be transferred to the union, we can do it far more easily, than get back those we may now imprudently give. ${ }^{220}$

Thus, the Federalist argument on permanency - that the Constitution should be drafted to survive future developments - did not escape criticism.

On the whole, however, the policy of avoiding potentially obsolescent language encountered remarkably little direct opposition. To avoid obsolescence, Federalists had abandoned principles that AntiFederalists considered essential to liberty and republican government, yet Anti-Federalists rarely denied the need for permanency. Even when Federalists justified broad federal power on the ground that a permanent rule could not otherwise be formulated, Anti-Federalists and other opponents of federal discretion usually did not decry the objective of a lasting constitution.

Why were the Anti-Federalists so quiet? Only proponents of the Constitution had reason to discuss its permanence. Anti-Federalists had no desire to praise the document for its permanence, yet they could not condemn the notion of a permanent constitution. Anti-Federalists tended to believe that the permanence of liberty and republicanism required permanent written limitations on government.

219. M. Smith in New York Ratification Convention, July 1, 1788, in 2 J. ElLIOT, supra note 1 , at 381-82.

220. He also said that it was safest "when we are sure we have given enough for ordinary exigencies, to be extremely careful how we delegate powers, which, in common cases, must necessarily be useless or abused, and of very uncertain effect in uncommon ones." Letters from the Federal Farmer, in 2 H. STORING, supra note 1, at 336. 
Therefore, Anti-Federalists could not easily disagree with the goal of a constitution drafted in a way that would allow it to be permanent.

Instead, Anti-Federalists employed other arguments. Some minimized the danger of obsolescence, arguing that the Federalists misperceived the likely course of future events. ${ }^{221}$ They also suggested alternative language, which would be as permanent as, but less dangerous than, that of the Constitution. ${ }^{222}$ Like the North Carolina delegation, quoted above, ${ }^{223}$ they wanted a constitution that would make both government and liberty permanent. ${ }^{224}$ As John Smilie said, "we do not ... contend for forms which it is certain may exist long after the substance has forever perished."225 Permanency for the form of government was an argument that was useful chiefly for Federalists, but it was an assumption about which most other framers and ratifiers typically agreed.

In sum, Anti-Federalists wanted a constitution that would permanently incorporate or fix certain essential obstacles. This goal of fixing limitations essential to liberty and republicanism was not necessarily incompatible with the Federalist insistence on avoiding constitutional obsolescence - indeed, the Federalists themselves shared the goal of fixed limitations. As it happened, however, Anti-Federalist notions of essential limitations included much that Federalists thought might render the Constitution temporary. Consequently, Federalists and Anti-Federalists had varying conceptions of what limitations should be contained in the Constitution, but they almost uniformly wanted their limitations to be established permanently. They wanted perma-

221. One Anti-Federalist explained that the vigor of the American people and the barrier formed by the ocean made standing armies unnecessary. Essays by Dewitt, in 4 H. STORING, supra note 1, at 38-39. For a similar position, see Essays of Brutus, in 2 id. at 403-04. On judicial salaries, see Letters from the Federal Farmer, in id. at 318.

222. Letters from the Federal Farmer, in 2 id. at 301 (on the regulation of elections) \& 284-85 (on apportionment); Essays of Brutus, in 2 id. at 416 (on standing armies) \& 398-400 (on power of taxation).

223. See supra text accompanying note 127.

224. Ratifiers were urged to inquire "where and how the essential powers shall be lodged to secure government, and to secure true liberty." Letters from the Federal Farmer, 2 H. STORING, supra note 1, at 232. Cornelius wrote: "I most ardently wish for an efficient, firm, and permanent system of government; and at the same time, that the people at large may enjoy as much liberty and ease, as may be consistent with such a government." Cornelius, Essay, in 4 id. at 146.

225. John Smilie in Pennsylvania Ratification Convention, Nov. 28, 1787, in 2 DocumeNTARY HISTORY, supra note 1 , at 410 . The Constitution's guarantee of the form of republicanism was hardly reassuring. See, e.g., Tredwell in New York Ratification Convention, July 2, 1788, in 2 J. Elliot, supra note 1, at 403; Lenoir in North Carolina Ratification Convention, July 30, 1788, in $4 \mathrm{id}$. at 202; Essays of Centinel, in 2 H. STORING, supra note 1, at 146, 151, 156-57; Letters from the Federal Farmer, in 2 id. at 276; Essays of Brutus, in 2 id. at 386; Symmes, Letter to Capt. Peter Osgoode, Jr., in 4 id. at 57; A Federal Republican, A Review of the Constitution...., in 3 id. at 78; Essays by the Impartial Examiner, in 5 id. at 179, 189; Letters from A Countryman, in 6 id. at 84; G. Clinton in New York Ratification Convention, July 11, 1788, in 6 id. at 184-85. 
nency for the limitations of the Constitution, and they wanted it for liberty and the republicanism of the government.

The next and concluding two Parts of this article examine the relationship of amendment and of language to the framers' and ratifiers' understanding of permanency.

\section{AMENDMENT}

According to Gordon S. Wood and William E. Nelson, the amendment provisions in American constitutions were understood by contemporaries to permit, among other things, adaptation of those constitutions to changes in American society. 226 Apparently, to the extent the framers and ratifiers thought adaptation of the Constitution either necessary or desirable, they considered amendment the means by which such adaptation should occur. The vast majority of the framers and ratifiers, however, seem to have assumed that - notwithstanding the possibility of using amendments to adapt the Constitution - constitutions could and should be permanent.

Of those who recognized a need for adaptation, most thought such adaptation should occur by amendment. Webster wanted constitutional change to occur by simple legislative enactment - in other words, almost no constitution; ${ }^{227}$ Jefferson wanted no constitution or other law to remain in effect for more than thirty-four years. ${ }^{228}$ However, others who indicated adaptation might be necessary or desirable appear to have assumed that amendment would be the means of changing the law. ${ }^{229}$

A great majority of the framers and ratifiers - even most of those who understood that amendments could be used for adaptation wanted a permanent constitution. As seen in their discussions of permanence, they sought a perfectible document rather than one that would merely be well suited to its circumstances. ${ }^{230}$ Although framers

226. G. WooD, supra note 48, at 613-14; Nelson, supra note 87 , at 507, 509-10.

227. Webster thought amendment too cumbersome and inefficient to permit prompt adaptation of the Constitution. Indeed, he questioned the right of one generation to impose a constitution on the next. See supra notes 141-44.

228. Letter from Thomas Jefferson to James Madison, Sept. 6, 1789, in 15 PAPERS of ThOMAS JEFFERESON 396, 398 n.15 (1958).

229. As discussed above, Federalists were quite explicit about this. See supra notes 137-40. Anti-Federalists were, of course, less willing to acknowledge that amendments would be possible, but they did not want judicial adaptation. See supra text accompanying note 102 .

230. By far the greatest number of references to amendment indicate that the framers and ratifiers viewed amendment, not necessarily as a means of adapting, but as an instrument for perfecting the Constitution. See, e.g., Convention Notes of James Madison, July 5, 1787 (comments of G. Bedford), in 1 M. FARRAND, supra note 1, at 532; Convention Notes of James Madison, June 5, 1787 (comments of E. Gerry), id. at 123; ThE FedERALIST, supra note 2, No. 85 (Hamilton), at 594; No. 14 (Madison), at 89; No. 37 (Madison), at 233; No. 43 (Madison), at 
and ratifiers who thought adaptation might be necessary believed amendments should be used for this purpose, they typically hoped adaptation would not be required and preferred to think of amendments as the means of perfecting the Constitution - of eliminating defects in a potentially permanent scheme. Edward Carrington not only assumed adaptation to be inconsistent with permanence but also perceived dangers in the process of repeated amendments:

The work once well done will be done forever, but patched up in accommodation to the whim of the day, it will soon require the hand of the cobbler again, and in every unfortunate experiment, the materials are rendered the less fit for that Monument of Civil liberty which we wish to erect. ${ }^{231}$

When examining the amendment provisions of some post-Revolutionary state constitutions, Cecelia Kenyon concluded that "their authors intended them to be used for 'perfecting' purposes - that is, correcting defects in the original constitutions that might be revealed by experience - not as means to adapt the constitutions to future change, growth, or progress in the society or the people." 232 The same can be said of the bulk of the framers and ratifiers of the federal Constitution.

296; Madison in Virginia Ratification Convention, June 20, 1788, in 3 J. ElLIOT, supra note 1, at 531; Convention Notes of James Madison, June 11, 1787 (comments of G. Mason), in 1 M. FARRAND, supra note 1, at 202-03; Pinckney, Observations, May 28, 1787, in 3 id. at 121; Speech by Wilson, in P. Ford, Pamphlets, supra note 1, at 161; Dickinson, Letters of Fabius, in id. at 181; Letter from Rufus King to Theophilus Parsons, Feb. 20, 1788, in 1 LIFE AND CoRRESPONDENCE OF RUFUS KING 321 (R. King ed. 1894). In a passage in his essay The Rise of Arts and Sciences, Hume wrote that constitutions can only be improved with time as inconveniencies are brought to light. Hamilton quoted that portion of Hume's essay in the last paragraph of the Federalist. Although most assertions of the perfecting role of amendment were made in the course of the debate about the Constitution's defects, such statements were in accord with the view that the Constitution could be and should be made permanent.

M. Lienesch writes: "Paradoxical as it seems, eighteenth century science made allowance for both theoretical permanence and practical improvement .... With the acceptance of an amendment procedure, they could argue that their system would provide both permanence and the possibility of reform." M. LIENESCH, supra note 32, at 135-37.

Anti-Federalists who wanted a gradual process of amendment were not thereby necessarily abandoning the goal of permanence. The clearest example was Luther Martin, who advocated continual amendment of the Constitution "from time to time as experience might point out its imperfections." This would be done " "till it could be made competent to every exigence of State, and afford at the same time ample security to Liberty and general Welfare." L. Martin in the Maryland House of Delegates, Nov. 29, 1787, in 3 M. FARRAND, supra note 1, at 152. Clearly, Martin urged a gradual process of perfecting the Constitution. See also Martin, Genuine Information, in 3 id. at 179-80; Letter from Lachland McIntosh to John Wereat, Dec. 17, 1787, in 3 Documentary History, supra note 1, at 260; A Letter From a Delegate Who Has Catched Cold, in 5 H. Storing, supra note 1, at 270; Letter from the Rev. James Madison to James Madison, Oct. 1, 1787, in 10 The PAPERS OF JAMES MAdison 185 (1977).

Note that many Federalists feared Anti-Federalists would seek destructive amendments.

231. Letter from Edward Carrington to James Madison, June 13, 1787, in 10 PAPERS OF JAMES MADISON 52.

232. Kenyon, Constitutionalism in Revolutionary America, in Constitutionalism, supra note 77 , at 115 . 


\section{INDETERMINACY}

As is clear from the evidence examined above, Federalists hoped that the Constitution would accommodate social change by excluding anything dependent upon temporary circumstances and instead relying on features of government and society that were permanent. The unlikely possibility remains, however, that Federalists wanted their use of generalities, principles, or vague language to permit constitutional law to be altered or adjusted to keep pace with the development of America's economy, values, and other social conditions. The contrary is strongly suggested both by the consent theory of constitutional law and by the extensive efforts of Federalists to make the Constitution permanent - to exclude from it language and even whole provisions that might have to be changed according to circumstances. Additional evidence as to whether indeterminacy was to be a means of adaptation can be found in Federalist opinions about constitutional language.

With respect to Anti-Federalists, it has been seen that although they did not dissent from the Federalist notion of permanency, they had their own perspective on the subject. They wanted to fix in the Constitution barriers that would protect the social foundations of liberty and, moreover, would protect liberty even once its social foundations had begun to crumble. As with the Federalists, it seems most improbable that they wanted these barriers to be flexible in response to changes in society. Nevertheless, their thoughts on language must be examined for further evidence on the subject.

In the remainder of this article, an examination of language will confirm that the framers and ratifiers, both Federalists and Anti-Federalists, did not want constitutional language - whether through vagueness, principles, or generalities - to be a source of indeterminacy. They assumed they were establishing fixed rather than flexible law. ${ }^{233}$ Of course, disagreements about the degree to which clarity

233. Garry Wills argues that Madison assumed the Constitution should be a flexibly interpreted "living document." G. Wills, Explaining AMERICA 54 (1981). In support of this, he presents three arguments. For his argument about the necessary-and-proper clause, see infra text at note 275 . For his argument about "liquidation" of language, see infra note 267 . The third argument is addressed here.

According to Wills, the Constitutional Convention was called to propose alterations to the Articles of Confederation but produced a new document instead. To justify the Convention's proposal, writes Wills, Madison in Federalist Number 40 had to take a very broad interpretation of the Convention's initial authorization. Wills views this example of broad interpretation as a "grant of freedom to interpret." G. Wills, Explaining AMERICA 51 (1981). Even if a "grant," however, it was not a grant to interpret freely. This is clear from the fact that Madison justified his interpretation by reference to rules of construction. More important, Madison argued that the people had a right to abolish or change their constitution. As a result, it seems difficult to draw conclusions from Federalist No. 40 about Madison's opinions on constitutional 
was achieved by the Constitution and about the meaning of its words were common from the start, but on the need for determinate language there was little dispute.

\section{A. Vagueness}

\section{The Epistemological Foundations of Language}

A variety of traditions encouraged Americans to seek clarity in language. ${ }^{234}$ Seventeenth- and eighteenth-century political disputes about the effect of statutes and charters, religious quarrels over the meaning of the Bible, and the inclinations and habits of lawyers had all for centuries inculcated an appreciation of linguistic precision. These traditions are sufficiently known that they need only be mentioned here as among the reasons that the framers and ratifiers were predisposed to desire clarity. However, another American perspective on language, derived from the epistemology of John Locke, may be less familiar and therefore requires a brief examination. Although the framers and ratifiers had little time or inclination to discuss epistemological theories underlying the language of the Constitution, at least one of them found it useful to do so, and it is significant that he turned to Locke's Essay Concerning Human Understanding.

In Federalist Number 37, Madison introduced the Federalist's analysis of the Constitution by encouraging Americans to examine the Constitution with a "spirit of moderation" - persons of a temperate character would recognize that a "faultless plan was not to be expected." 235 In particular, they would perceive that "many allowances ought to be made for the difficulties inherent in the very nature of the undertaking . ..."236 Madison then proceeded to examine a variety of these difficulties faced by the Convention. Among these was the difficulty of accurately defining federal and state authority, and it was in connection with this that Madison wrote one of the most elegant and sophisticated accounts of constitutional imprecision.

Although it is recognized that Federalist Number 37 reflects Lockean assumptions, the degree to which Madison's analysis was deriva-

interpretation. What the people may do with their constitution and what judges may do with it are hardly comparable.

234. It is possible for the words "vague," "inexact," "unclear," and "imprecise" to have slightly different meanings. Since this article has no occasion to make such distinctions, it uses the words as synonyms. Similarly, no distinction is made between "clear" and "precise."

For Anti-Federalist views on vagueness, see Kenyon, Men of Little Faith: The Anti-Federalists on the Nature of Representative Government, 12 WM. \& MARY Q. 3, 21-22 (1955) [hereinafter Kenyon, Men of Little Faith].

235. The Federalist, supra note 2, No. 37 (Madison), at 232.

236. Id. at 233. 
tive has not been pursued. ${ }^{237}$ In fact, Madison paraphrased Locke's arguments about the inevitable imprecision arising from human ideas, faculties, and language. ${ }^{238}$ Locke had argued that ideas were either "simple" or "complex," simple ideas being produced by single sensations, and complex ideas requiring combinations of the simple. ${ }^{239}$ This analysis allowed Madison to justify the vagueness of the Constitution's distinction between state and federal power, for Locke had shown that some imprecision in such matters was unavoidable. According to Locke and now Madison, political principles are complex ideas that are liable to be indistinctly conceived, and the indistinctness of these complex ideas inevitably produces obscurity. Continuing to draw on Locke, Madison noted that a second source of uncertainty was the imperfection of "human faculties." 240 A third explanation of vagueness, also derived from Locke, concerned the "vehicle of ideas," language. Although language can provide a word for each simple idea, it is not "so copious as to supply words and phrases for every complex idea." ${ }^{241}$ As a result, a word is often used for more than one idea and thereby creates additional vagueness "according to the complexity and novelty of the objects defined." The drafters had to contend with all three of these sources of "vague and incorrect definitions" - the "indistinctness" of complex ideas or objects, the "imperfection of the organ of conception," and the "inadequateness of the vehicle of ideas." ${ }^{42}$ Consequently, "a certain degree of obscurity" was inevitable. ${ }^{243}$ To illustrate this point, Madison borrowed not only Locke's

237. R.L. Ketcham speculated about the possible influence of Locke's Essay upon Madison's Federalist Number 10. He did not, however, notice Madison's use of it in number 37. He wrote that "[t]here is no explicit reference to the Essay in Madison's extant writings." Ketcham, James Madison and the Nature of Man, 19 J. HIST. IDEAS 62, $71-73$ \& n.31 (1958). James Farr writes that Madison in Federalist Number 37 "gave vent to the widely held Lockean and Humean view that 'words . . . express ideas." Farr, Conceptual Change and Constitutional Innovation, in Conceptual Change and the Constitution 13, 16 (T. Ball \& J. Pocock eds. 1988). With greater precision, D.F. Epstein has described the passage in number 37 as "a short essay concerning human understanding." D. EPSTEIN, supra note 200, at 114. As will be seen, Madison in Federalist Number 37 directly borrowed Locke's very arguments and language.

Stephen Conrad has examined Wilson's epistemology concerning morals. Conrad, supra note 53, at 359. Morton White has discussed Locke's epistemology of self-evident principles and its influence upon Jefferson, Hamilton, and other revolutionaries. See M. WHITE, supra note 65, at 61-96.

238. This is yet another example of Madison's ability to employ with economy ideas that another author had discussed at length. On Madison's facility in this regard, see Adair, supra note 53 , at 104-05.

239. J. Locke, Essay Concerning Human Understanding bk. II (1690).

240. The Federalist, supra note 2, No. 37 (Madison), at 235-36, drawing on J. LocKE, supra note 239, at bk. IV, ch. iii, §23.

241. The Federalist, supra note 2, No. 37 (Madison), at 236, drawing on J. LocKE, supra note 239 , at bk. III, ch. iii.

242. The Federalist, supra note 2, No. 37 (Madison), at 237

243. Id. at 237. 
arguments but also his most startling example: "When the Almighty himself condescends to address mankind in their own language, his meaning, luminous as it must be, is rendered dim and doubtful, by the cloudy medium through which it is communicated." 244 It was a thought with which Locke no doubt had already caught the attention of many eighteenth-century Americans.

Like Locke, however, Madison had no inclination to surrender to the imprecision of language. Locke had sought to determine the capacity of humans to understand themselves and their surroundings. Therefore, he had investigated the imperfection of ideas, faculties, and language and the extent to which they could be freed from obscurity. Madison borrowed from Locke to show the impossibility of absolute precision in language, but he also shared with Locke a belief that language could be somewhat precise and that precision was desirable. For example, in Federalist Number 37, Madison aimed to discourage hopes for a "faultless" demarcation of federal and state jurisdictions, and during the ratification debates he pointed out that "precision was not so easily obtained as may be imagined." 245 In both instances, however, he appears to have assumed that precision in constitutional language was desirable whenever possible. Hence, the aptness of Madison's borrowing from Locke. ${ }^{246}$

Any discussion of the epistemology underlying constitutional lan-

244. Id. at 236-37. Locke wrote that "the will of God, when clothed in words, [was] liable to that doubt and uncertainty which unavoidably attends that sort of conveyance . . ." J. LOCKE, supra note 239, at bk. III, ch. ix, § 23. Locke's Essay may also lurk behind other passages of The Federalist Number 37. At the beginning of that number, Madison argues that a "just estimate" of the Constitution requires a "spirit of moderation." THE FEDERALIST, supra note 2, No. 37 (Madison), at 231.

245. Madison in Virginia Ratification Convention, June, 20, 1788, in 3 J. Elliot, supra note 1, at 531-32. In defense of Congress' power over the militia, he insisted that "[n]othing can be more certain and positive than this." Madison in Virginia Ratification Convention, June 14, 1788 , in 3 id. at 424.

246. Locke's Essay had raised the possibility that language could only possess the various meanings attributed to it by different readers. Prior commented, "If no Mans Ideas be perfectly the same, Locks Human Understanding may be fit only for the Meditation of Lock himself." K. Maclean, John Locke and English Literature of the Eighteenth Century 111 (1936). However, Locke wrote to William Molyneux:

If I could think that discourses and arguments to the understanding were like the several sorts of cates [food] to different palates and stomachs, some nauseous and destructive to one, which are pleasant and restorative to another; I should no more think of books and study, and should think my time better imploy'd at push-pin than in reading or writing. But I am convinc'd of the contrary: I know there is truth opposite to falshood, that it may be found if people will, and is worth the seeking, and is not only the most valuable, but the pleasantest thing in the world.

Letter from John Locke to William Molyneaux, Jan. 1698, quoted in Kloppenberg, The Virtues of Liberalism: Christianity, Republicanism, and Ethics in Early American Political Discourse, 74 J. AM. HIST. 9, 16 n.9 (1987). Locke and apparently most of his eighteenth-century readers were not resigned to an anarchy of meaning. They believed that language could be made relatively precise. 
guage was most unusual in the late eighteenth century, yet Madison's analysis is a reminder of Locke's influence upon American epistemological thought in that period. ${ }^{247}$ Locke's Essay occupies a prominent place in surviving, pre-1791 American library lists. ${ }^{248}$ It served as a text at some American schools, ${ }^{249}$ and its ideas probably reached other Americans through Isaac Watts' Logick of 1725.250 To the extent that Americans engaged in epistemological thought about language, including constitutional language, they began with the remarkable arguments in Locke's Essay. ${ }^{251}$ Perhaps more important, the Essay contributed much to eighteenth-century American assumptions about language. ${ }^{252}$ Thus, Locke's Essay should be considered together with the traditions mentioned above as one of the various intellectual influences that probably encouraged Americans - particularly, in the case of the Essay, well-educated Americans - to distrust imprecision and uncertainty in language.

\section{Vagueness and Interpretation}

Not surprisingly, the framers and ratifiers appear to have assumed that they should try to avoid vagueness or imprecision in the Constitution. In at least two colloquies during the framing convention, future Federalists and Anti-Federalists sought to eliminate vagueness from

247. The epistemological works of Berkeley and Hume apparently were not as widely influential in America in the eighteenth century. Berkeley's Treatise Concerning the Principles of Human Knowledge and Hume's Inquiry Concerning the Principles of Morals appear relatively infrequently in eighteenth-century American library lists. Berkeley's book turns up 13 times and Hume's 7 times in 121 pre-1791 lists. Lundberg \& May, supra note 59. Note that Madison studied Berkelean criticisms of Locke at Donald Robertson's school. See 1 I. BRANT, JAMES MADISON 61 (1941).

248. Lundberg \& May, supra note 59, at 268; see also Lutz, The Relative Influence of European Writers on Late Eighteenth Century American Political Thought, 78 AM. PoL. SCI. Rev. 189, 196 (1984).

249. A. HadDow, supra note 71 , at 15, 53, 82. For evidence that the Essay was used at Princeton and at Donald Robertson's school, see 1 I. BRANT, JAMEs MADISON 61, $76-77$ (1941). Jonathan Edwards read the Essay at Yale and found in it "greater pleasure "than the most greedy miser finds, when gathering up handfuls of silver and gold, from some newly discovered treasure." ' K. MACLEAN, supra note 246, at 7.

250. I. Watts, Logick: Or, The Right Use of Reason in the Enquiry after Truth (1725). Watts sent copies to libraries in Connecticut and Massachusetts. W. Howell, EIGHTeenth Century British Logic and Rhetoric 341-42, 345 (1971).

251. Locke's ideas dominated eighteenth-century views on epistemology and language. For his influence in America, see P. MILLER, ERRAND INTO THE WILDERNESS 168 (1956). For his influence in England, see W. Howell, supra note 250, at 264-98, passim.

252. For Americans' Lockean assumptions about language, see supra note 237. A similar argument has been made about Lockean assumptions in England. See K. MACLEAN, supra note 246. MacLean examines how leading eighteenth-century English essayists and novelists employed or rejected Locke's epistemological ideas, and he thereby suggests that educated Englishmen frequently assumed or knew of some basic Lockean tenets. 
the Constitution's provisions. ${ }^{253}$ In both the framing and the ratification debates, everyone who spoke or wrote about a lack of clarity argued on the assumption that it was undesirable.

Anti-Federalists vigorously attacked the Constitution on the ground of vagueness. ${ }^{254}$ Cecelia Kenyon has written:

In recent years the Constitution has been much admired for its brevity, its generality, its freedom from the minutiae which characterized nineteenth-century constitutions. These qualities were feared and not admired by the Anti-Federalists. They wanted detailed explicitness which would confine the discretion of Congressional majorities within narrow boundaries. ${ }^{255}$

Anti-Federalists claimed that uncertainties in the text would permit "different constructions," including dangerous ones. For example, as will be seen below, Anti-Federalists feared reliance upon constructive or implied rights.

Similarly, some of the most prominent Anti-Federalist writers raised the spectre of judges who would expand the Constitution's provisions for federal authority (congressional and judicial). Judges would accomplish this by employing various devices, including their equitable powers, the "general and indefinite terms" of the Constitution, and arguments based on the document's "reason and spirit." 256 "Brutus" wrote that federal judges would adjust constitutional law to meet new circumstances. Judges, he explained, were empowered to construe the Constitution in equity. Citing Grotius, Brutus wrote that equity is

"the correction of that, wherein the law, by reason of its universality, is deficient["]; for since in laws all cases cannot be foreseen, or expressed, it is necessary, that when the decrees of the law cannot be applied to particular cases, there should some where be a power vested of defining those circumstances, which had they been foreseen the legislator would

253. Convention Notes of James Madison, Aug. 16, 1787, in 2 M. FARRAND, supra note 1, at 305; id. at 316 (Aug. 17, 1787); Dickinson, Plan of Government, in M. FARRAND, supra note 1, at 90 (Supp. 1987).

254. For just a few of many more examples, see Letter from Elbridge Gerry to President of the Senate and Speaker of the House of Representatives of Massachusetts, Oct. 18, 1787, in 3 M. FARRAND, supra note 1, at 128; Letter from Edmund Randolph to the Speaker of the Virginia House of Delegates, Oct. 10, 1787, in id. at 127; M. Smith in New York Ratification Convention, June 17, 1788, in 2 J. Elliot, supra note 1, at 243; Caldwell in North Carolina Ratification Convention, July 23, 1788, in 4 id. at 187; Resolution in North Carolina Ratification Convention, July 23, 1788, in id. at 242; Galloway in North Carolina Ratification Convention, July 23, 1788, in id. at 70; Bloodworth in North Carolina Ratification Convention, July 23, 1788, in id. at 34 \& 50; Letters of Cato, in P. ForD, EsSAYS, supra note 1, at 265; Spencer in North Carolina Ratification Convention, July 23, 1788, in 4 J. Elliot, supra note 1, at 54, 65, 68.

255. Kenyon, Men of Little Faith, supra note 234, at 3, 21-22.

256. Essays of Brutus, in 2 H. STORING, supra note 1, at 420; see also id. at 417-28, 436-42; Letters from the Federal Farmer, in 2 H. STORING, supra note 1, at 315-16, 322-23; Clinton, Notes of Speeches. .., in 6 H. STORING, supra note 1, at 184. 
have expressed . . . 257

Brutus warned that federal judges, in the guise of interpretation, might alter the meaning of the Constitution to expand federal power. ${ }^{258}$ One Anti-Federalist concluded that the judiciary was the most dangerous branch. ${ }^{259}$

In response to the allegations of vagueness and Anti-Federalist fears of different or dangerous constructions, Federalists insisted that the Constitution was clear ${ }^{260}$ or at least as clear as possible in light of both linguistic and political difficulties. ${ }^{261}$ As has been seen, Madison

257. Essays of Brutus, in 2 H. STORING, supra note 1, at 419-20. He explained that the judges "will be able to extend the limits of the general government gradually, and by insensible degrees, and to accommodate themselves to the temper of the people." Id. at 441; see also Letters from the Federal Farmer, in 2 H. STORING, supra note 1, at 244.

258. According to another Anti-Federalist, the judges "may by a Number of legal Decisions, make what Constitution they Please for the united States." Letter from Samuel Osgood to Samuel Adams, Jan. 5, 1788, in 15 Documentary History, supra note 1, at 265; see also A Minority of the Maryland Ratifying Convention, 5 H. STORING, supra note 1, at 95.

Some expressed hope for language that would not require any interpretation. See Powell, supra note 7, at 889-94.

259. Letters from the Federal Farmer, in $2 \mathrm{H}$. STORING, supra note 1, at 316; see also A Columbian Patriot, Observations on the Constitution, in 16 DocumentaRy History, supra note 1 , at 279.

Everything known about the framers' and ratifiers' general perceptions of the judiciary suggests that they did not desire that branch to construe the Constitution in a way that would alter its meaning, let alone in a way that would flexibly adjust it to changing circumstances. It is well known that the framers and ratifiers desired a judiciary that would be restricted to the limited role of applying rather than making law.

260. Madison in Virginia Ratification Convention, June 2, 1788, in 3 J. ElLIOT, supra note 1, at 424 (on subject of defense); T. McKean in Pennsylvania Ratification Convention, Nov. 28, 1787 , in 2 DOCUMENTARY History, supra note 1, at 413 (on subject of legislative article); Middlesex Gazette, Oct. 22, 1787, 3 id. at 395 (on whole Constitution); Wilson in Pennsylvania Ratification Convention, Dec. 7, 1787, in 3 M. FARRAND, supra note 1, at 163 (on subject of treason); C. Strong in Massachusetts Ratification Convention, Jan. 16, 1788, in 3 M. FARRAND, supra note 1, at 248; Spaight in North Carolina Ratification Convention, July 24, 1788, in 4 J. Elliot, supra note 1, at 210; Iredell in North Carolina Ratification Convention, July 24, 1788, in id. at 171-72; Webster, Examination, in P. Ford, PAMPHLETS, supra note 1, at 53. According to one writer, the Constitution "intentionally with precision defines and limits" the powers of the "rulers." Thus, it "firmly and stably fixeth the boundaries of their authority, beyond which they cannot pass, unless in violation of the Constitution ...." Anti-Cincinnatus, Northampton Hampshire Gazette, Dec. 19, 1787, in 15 Documentary History, supra note 1, at 37 . Another sought to "exhibit clear and permanent marks and lines of separate sovereignty." A Freeman I [T. Coxe], Pennsylvania Gazette, Jan. 23, 1788, in id. at 455.

261. See, e.g, Wilson in Pennsylvania Ratification Convention, in 2 Documentary HisTORY, supra note 1, at 355, 493; R. King in Massachusetts Ratification Convention, Jan. 24, 1788, in 3 M. FARRAND, supra note 1, at 268; Madison in Virginia Ratification Convention, June 15,1788 , in $3 \mathrm{~J}$. Elliot, supra note 1, at 438; Letter from Governeur Morris to Timothy Pickering, Dec. 22, 1814, in 3 M. FARRAND, supra note 1, at 420; The Federalist, supra note 2, No. 83 (Hamilton), at 572-73; Parson in Massachusetts Ratification Convention, Jan. 25, 1788, in 2 J. Elliot, supra note 1, at 104; Dickinson, Letters of Fabius, in P. FoRD, PAMPHLETS, supra note 1 , at 174 .

In a discussion of federal discretion, Jasper Yates spoke about "ambiguity" as if he thought it desirable. In fact, he was referring to the desirability of some discretion. J. Yates in Pennsylvania Ratification Convention, Jan. 5, 1788, in 2 DocumeNTARY HisTORY, supra note 1, at 438 . 
was particularly eloquent on the inevitability of imprecision. He took this position, however, to suggest that the Constitution was as precise as it could be made. ${ }^{262}$

Even while protesting that some lack of clarity was unavoidable, Federalists revealed their expectations that interpretation would lead to certainty. Madison argued in the middle of his Lockean analysis of imprecision that obscure points in the Constitution would be resolved and made certain by case law: "All new laws, though penned with the greatest technical skill, and passed on the fullest and most mature deliberation, are considered as more or less obscure and equivocal, until their meaning be liquidated and ascertained by a series of particular discussions and adjudications." 263 As Madison explained to Samuel Johnston in 1789, the "exposition of the Constitution" would be a "copious source" of difficulties "until its meaning on all great points shall have been settled by precedents." 264 Madison's words - "ascertain," "settle," and "liquidate" - all indicate that he expected vagueness in the Constitution to be resolved and made certain rather than that it would be an opportunity for flexibility and judicial adaptation of the Constitution to changing exigencies. ${ }^{265}$ It may be no coincidence that Hamilton not only had similar thoughts but expressed them in similar language: "The erection of a new government, whatever care or wisdom may distinguish the work, cannot fail to originate questions of intricacy and nicety.... 'Tis time only that can mature and perfect so compound a system [and] . . . liquidate the meaning of all the parts . . . "266 Because it would be liquidated, even a lack of clarity allowed hope for certainty. ${ }^{267}$

262. See supra text accompanying note 235.

263. The Federalist, supra note 2, No. 37 (Madison), at 236.

264. Letter from James Madison to Samuel Johnston, June 21, 1789, in 12 PAPERS OF JAMES MAdison 250 (1979). Johnston agreed with Madison. See Letter from Samuel Johnston to James Madison, July 8, 1789, in id. at 285. More than 30 years later, Madison again explained: It could not but happen, and was foreseen at the birth of the Constitution, that difficulties and differences of opinion might occasionally arise in expounding terms and phrases necessarily used in such a charter; . . . and that it might require a regular course of practice to liquidate and settle the meaning of some of them.

Letter from James Madison to Judge Roane, Sept. 2, 1819, in 3 M. FARRAND, supra note 1, at 435. Later, Madison wrote that "[t]he extent of the powers to be vested, also tho' expressed in loose terms, evidently had reference to limitations \& definitions, to be made in the progress of the work, distinguishing it from a plenary \& Consolidated Govt." Letter from James Madison to N.P. Trist, Dec. 1831 , in id. at 517.

265. On this subject, see Kay, Adherence to the Original Intentions in Constitutional Adjudication: Three Objections and Responses, 82 Nw. U. L. REV. 226, 277 (1988); Powell, supra note 7 , at $885,939-41$. "Liquidate" means to ascertain or fix; to make clear or plain; to remove ambiguity. OXFORD ENGLiSh Dictionary 1012 (2d ed. 1989).

266. The Federalist, supra note 2, No. 82 (Hamilton), at 553; see also id., No. 78 (Hamilton), at 525 .

267. See also Nathan Dane's discussion of how the initial organization of the government 
Although only Madison and Hamilton appear to have descanted on the liquidation of meaning, other Federalists also argued that interpretation would resolve difficulties. Federalists explained repeatedly how each alleged uncertainty had or would be given an acceptable, fixed signification. Interpretation of the Constitution would settle uncertainties rather than use them to permit flexibility. 268

This conclusion is not inconsistent with the well-known fact that the framers and ratifiers occasionally referred to a "liberal interpretation." The Anti-Federalists who used this phrase to mean a broad interpretation clearly were critical of such a construction. ${ }^{269}$ Moreover, although a few leading Federalists advocated a "liberal construction" of the Constitution, they did so while trying to convince their opponents that the Constitution had an identifiable and acceptable interpretation. They were not suggesting that constitutional law should be flexible.

For example, Randolph argued for a liberal construction in the course of justifying the "necessary and proper" provision, which (as he noted) Anti-Federalists had labelled the "sweeping clause." Randolph

would cure ambiguities. Letter from Nathan Dane to Caleb Strong, Oct. 10, 1787, in 13 DocuMENTARY HISTORY, supra note 1, at 356. Abraham Baldwin later said:

[I]t was not supposed by the makers of it at the time, but that some subjects were left a little ambiguous and uncertain. It was a greater thing to get so many difficult subjects definitely settled at once. ... The few that were left a little unsettled might, without any great risk, be settled by practice or by amendments in the progress of the Government.

A. Baldwin in the House of Representatives, March 14, 1796, in 3 M. FarRand, supra note 1, at 370 .

According to Wills, Madison's discussion of the liquidation of meaning is evidence that Madison desired a "broad construction" and a "living document." G. WILLS, ExPLAINING AMERICA 54 (1981). He bases this conclusion on two rather tenuous assumptions, namely, that Madison believed future construction of the Constitution should be the product of compromises, and that such a belief is the same as a belief in a "living constitution." Wills cites no evidence for either proposition. True, Madison referred to the compromises in the 1787 Convention as proof that a spirit of reasonableness would prevail in construction of the document. That is not, however, evidence of his desire for compromise in constitutional adjudication, let alone for flexible interpretation or a "living document."

268. Alexander Contee Hanson responded directly to the Anti-Federalist argument that federal courts would use fictions to expand their jurisdiction. Fictions, said Hanson, "were ingenious devices, to remedy defects in the common law, without the aid of parliament." Hanson, Remarks, in P. FORD, PAMPHLETS, supra note 1, at 239-40. "[C]an any man seriously imagine," he asked,

that fiction will be permitted, to give the judges a power of legislation, denied to congress itself? Wherefore should the judges, holding their commissions during good behaviour, be guilty of such gross falsehood, perjury, and breach of trust? Would there not be a general revolt against such barefaced impudent innovations.

Id. at 240 .

269. Brutus referred to a "liberal construction," meaning a broad interpretation. See Essays of Brutus, in 2 H. STORING, supra note 1, at 427. For other usages, see Essays by A Farmer, 4 id. at 209; Essays by an Impartial Examiner, 5 id. at 174. James Monroe criticized the Constitution because it did not satisfy his wish "to see the right of impeachment, extended upon as liberal ground as possible." Monroe, Some Observations on the Constitution, in 5 H. STORING, supra note 1, at 296; Ramsay, 1 First Federal Elections, supra note 1, at 175. 
conceived that "the construction which had been put on this clause by the advocates of the Constitution was too narrow, and that the construction put upon it by the other party was extravagant." 270 In arguing against the excessively narrow interpretation, Randolph explained: "A constitution differs from a law; for a law only embraces one thing, but a constitution embraces a number of things, and is to have a more liberal construction." Whereas "European constitutions" sometimes consisted of a series of "detached" laws or customs, the new federal Constitution (like other American constitutions) was "singular" and therefore had to "embrace a number of things." As a result, it "is to have a more liberal construction." 271 Clearly, Randolph thought the proper interpretation was more generous than that propounded by other Federalists, but he also attacked the Anti-Federalist construction, which he believed was too broad. Although he argued that the nature of a single constitution required a liberal interpretation, he did not suggest that constitutional law should be alterable in response to circumstances.

Madison also asked for a "liberal interpretation," but he apparently did not mean one that was broad. He said that the difficulty of drafting the Constitution's language concerning executive power

claims the indulgence of a fair and liberal interpretation. I will not deny that, according to my view of the subject, a more accurate attention might place it in terms which would exclude some of the objections now made to it. But if we take a liberal construction, I think we shall find nothing dangerous or inadmissible in it. ${ }^{272}$

Objections had been taken to the scope of executive power. Apparently, Madison thought a liberal construction of the language would not be so broad as to be dangerous. Thus, when urging "the indulgence" of a "liberal" construction, Madison probably meant an interpretation that would be fair or natural or that would be made in a generous spirit. ${ }^{273}$ Hence, a "fair and liberal interpretation." 274

270. Randolph in Virginia Ratification Convention, June 15, 1788, in 3 J. ElLIOT, supra note 1 , at 463 .

271. Id.

272. Madison in Virginia Ratification Convention, June 20, 1788, in 3 J. ElLIOT, supra note 1 , at 531 .

273. Madison's use of "liberal" in the sense of "natural," is coherent with the possibility that he was also suggesting a nontechnical interpretation.

An example of the use of the word "liberal" to mean "natural" is provided by the AntiFederalist who justified his interpretation of the Constitution on the ground "that it is not a forced, but a very liberal construction . . . ." Consider Arms, Malichi Maynard, and Samuel Field, Reasons for Dissent, in $4 \mathrm{H}$. STORING, supra note 1, at 263. For evidence that Federalists used "liberal" to suggest, inter alia, "nontechnical," see infra note 274. In this connection, note that Hamilton argued for a "natural and obvious" rather than a "technical" interpretation. THE Federalist, supra note 2, No. 83 (Hamilton), at 560.

274. Madison in Virginia Ratification Convention, June 20, 1788, in 3 J. ElLIOT, supra note 
Madison's account of a "liberal" interpretation did not suggest that constitutional law should change with the development of society.

According to Garry Wills' analysis of Federalist Number 44, Madison advocated the broadest possible construction of the necessary-and-proper clause and thereby indicated his desire "for a very adaptable and flexible instrument reflecting the needs of social man." 275 In fact, Madison did not argue in Federalist Number 44 for the broadest possible construction of the necessary-and-proper clause. Rather, he sought to justify the broad discretion that Anti-Federalists thought it expressly granted to Congress. He did this by explaining that alternative formulations would have been even less satisfactory. ${ }^{276}$ Wills does not mention that Madison concluded the relevant passage of the Federalist by drawing attention to the remedies, judicial and political, that would be available if Congress were to "misconstrue" the clause and were to "exercise powers not warranted by its true meaning." 277 Of course, Madison understood that what was "necessary and proper" would change with circumstances. This was, however, something those words accomplished expressly. Madison argued that, unlike a positive enumeration of the necessary and proper powers, the Constitution's language was "accommodated . . . to all the possible changes which futurity may produce." Similarly, Iredell justified the language as being designed to permit Congress to provide for unforeseeable contingencies. ${ }^{278}$ Both of these Federalists were advocating permanent rather than indeterminate language.

1, at 531. He then turned to the problems connected with technical terms. It is possible that in so doing he was continuing to discuss some of the language that required a liberal interpretation. If so, Madison's understanding of the reasons for a liberal interpretation were connected to the nature of the Constitution, as were Randolph's, and a "liberal construction" would imply a nontechnical one. Many years later, Madison pointed out that the government of the United States was "a novelty \& a compound" and therefore "had no technical terms or phrases appropriate to it; and that old terms were to be used in new senses, explained by the context or by the facts of the case." Letter from James Madison to N.P. Trist, Dec. 1831, in 3 M. FARRAND, supra note 1, at 517 .

275. G. Wills, Explaining America 47, 54 (1981).

276. Wills also says that Madison was arguing against his own tactical interests. Id. at 52 .

277. The Federalist, supra note 2, No. 44 (Madison), at 305. Madison wrote:

In the first instance, the success of the usurpation will depend on the executive and judiciary departments, which are to expound and give effect to the legislative acts; and in the last resort, a remedy must be obtained from the people, who can by the election of more faithful representatives, annul the acts of the usurpers.

Id. at 305; see also Madison in Virginia Ratification Convention, June 2, 1788, in $3 \mathrm{~J}$. EllioT, supra note 1 , at 438 .

278. Iredell, Answer to Mr. Mason's Objections to the New Constitution, in P. Ford, PaMPHLETS, supra note 1 , at 356. 


\section{Vagueness and Rights}

In case it may be thought that rights were thought of differently than other parts of the Constitution, it should be noted that both Federalists and Anti-Federalists indicated a desire to avoid vagueness in the protection of rights.

Although they frequently discussed the Constitution as if it had not provided for most rights, the framers and ratifiers also at times addressed the Constitution's treatment of rights in terms of vagueness. Some Federalists insisted that the 1787 text of the Constitution defined federal powers with relative precision and thereby provided protection for the people's rights. ${ }^{279}$ According to Anti-Federalists, however, the Constitution's definition of federal power left only uncertain protection for rights. Anti-Federalists complained that rights existed under the Constitution only by "construction" or "implication," 280 and therefore they wanted amendments to establish rights "clearly," "expressly," and "explicitly."281 A bill of rights was needed so that the

279. See, e.g., Iredell in North Carolina Ratification Convention, July 28, 1788, in 4 J. ELLIOT, supra note 1, at 148-49; Maclaine in North Carolina Ratification Convention, July 28, 1788, in id. at 140-41; Dana in Massachusetts Ratification Convention, Jan. 26, 1788, in 2 id. at 108-09 (regarding habeas corpus). For discussion of this point of view, see Rossum, The Federalist's Understanding of the Constitution as a Bill of Rights, in SAVING THE REvolution 219-33 (C. Kesler ed. 1987).

280. Henry in Virginia Ratification Convention, June 5, 7, 12 \& 14, 1788, in $3 \mathrm{~J}$. ElliOT, supra note 1, at 46, 149, 318, 422; Mason in Virginia Ratification Convention, June 23, 1788, in id. at 585; Williams in New York Ratification Convention, June 27, 1788, in 2 id. at 338 (regarding the rights of states); Letters of Centinel, in 2 H. STORING, supra note 1, at 147; Letters from the Federal Farmer, in id. at 324. One Anti-Federalist wrote that without a bill of rights the Constitution "will render our priviledges as undefined as . . . are those of the subjects of England; which are only to be 'collected from meer opinions of the learned and contradictory authors.", Essay by One of the Common People, in 4 id. at 120. Another said he had not expected that the right to a jury in civil cases would be "left dependent on the arbitrary exposition of future judges, who, when it may suit the arbitrary views of the ruling powers will explain it away at pleasure." Essays by Cincinnatus, in 6 id. at 12 .

281. The Federal Farmer wrote that people "like to be express and explicit about their essential rights"; he wanted to establish rights "beyond dispute." Letters from the Federal Farmer, in 2 id. at 324, 329. "These rights should be made the basis of every constitution: and if a people be so situated, or have such different opinions that they cannot agree in ascertaining and fixing them, it is a very strong argument against their attempting to form one entire society ...." Id. at 232. Brutus wrote:

When a building is to be erected which is intended to stand for ages, the foundation should be firmly laid. The constitution proposed to your acceptance, is designed not for yourselves alone, but for generations yet unborn. The principles, therefore upon which the social compact is founded, ought to have been clearly and precisely stated, and the most express and full declaration of rights to have been made - But on this subject there is almost an entire silence.

Essays of Brutus, in id. at 372. For just some of the other examples, see Tyler in the Virginia Ratification Convention, June 25, 1788, in 3 J. EllioT, supra note 1, at 642; Dawson in Virginia Ratification Convention, June 25, 1788, in id. at 612; Henry in Virginia Ratification Convention, June 20, 1788, in 3 id. 10 at 541; Jones in New York Ratification Convention, June 25, 1788, in 2 id. at 325; Thompson in Massachusetts Ratification Convention, Jan. 23, 1788, in id. at 80; Mason in Massachusetts Ratification Convention, Feb. 1, 1788, in id. at 137 (regarding habeas corpus); Lenoir in North Carolina Ratification Convention, July 30, 1788, in 4 id. at 202; Spencer 
measure of the people's rights would not depend upon judicial construction. ${ }^{282}$

To a limited degree, attitudes about vagueness are apparent in the meager surviving debates on the Bill of Rights. During ratification of the Constitution, various enumerations of rights were demanded, but the exact formulation of a bill of rights was not yet an issue and so was not much discussed. The 1789 Congress, however, drafted the Bill of Rights and therefore debated its language in some detail. In all known instances, allegations of uncertainty apparently were pursued or were considered either insubstantial or insoluble. ${ }^{283}$ For example, Livermore complained about the vagueness of the "cruel-and-unusualpunishment" language, but he seems to have been ignored by his colleagues. Conceivably, they did not perceive or did not care about the lack of clarity. More probably, they could think of no better, alternative language and felt a political need to include the provision. ${ }^{284}$ No one at any point in the debates about rights is recorded as having suggested that vagueness was desirable.

The ninth and tenth amendments include what seem to be obvious

in North Carolina Ratification Convention, July 28 \& 29, 1788, in id. at 137, 153; Bloodworth in North Carolina Ratification Convention, July 29, 1788, in id. at 167; Dissent of Minority in Pennsylvania Ratification Convention, Dec. 18, 1788, in 2 DOCUMENTARY HISTORY, supra note 1, at 630; Smith, An Address to the People of the State of New York, in P. Ford, PAMPHLETS, supra note 1, at 113; R.H. Lee in Continental Congress, Sept. 27, 1787, in 13 DocumentARY History, supra note 1, at 238-39; Z, Boston Independent Chronicle, Dec. 6, 1787, in 14 DocuMENTARY HISTORY, supra note 1 , at 359.

282. Initially, Madison had seen no need for a bill of rights, since he perceived no difference between a grant of limited power to the federal government and a statement of rights belonging to the people and the states. As is well known, however, he came to acknowledge the usefulness of an enumeration of rights as a means of further defining and strengthening limitations on federal power. In the House or Representatives, he was the chief proponent and drafter of the Bill of Rights.

283. For example, on juries from the "vicinage," see Letter from James Madison to Edmund Pendleton, Sept. 23, 1789, in B. SchwartZ, Bill of Rights, supra note 1, at 1166 . On the right to bear arms, see Stone, Benson, and Gerry in the House of Representatives, Aug. 17, 1789, in id. at 1109 . Elbridge Gerry in the House said that the amendment "ought to be "deny or impair,' for the word 'disparage' was not of plain import . . . ." He then moved to make the alteration, but he was not seconded. See id. at 1112; see also infra note 284.

284. 2 B. Schwartz, Bill of Rights, at 1111-12. Earlier, Iredell had said that "cruel and unusual" was vague. Indeed, he thought that if included in the Constitution it "would have been too vague to have been of any consequence." Iredell also objected to the alternatives:

If . . . the Convention had enumerated a vast variety of cruel punishments, and prohibited the use of any of them, . . . and if our government had been disposed to be cruel their invention would only have been put to a little more trouble. . . . If to avoid this difficulty, they had determined ... positively what punishments should [be used], this must have led them into a labyrinth of detail which in the original constitution of a government would have appeared perfectly ridiculous, and not left a room for such changes, according to circumstances, as must be in the power of every Legislature that is rationally formed.

Iredell, Answer to Mr. Mason's Objections to the New Constitution, in P. Ford, PAMPhLETs, supra note 1, at 360. On this subject, Webster was caustic. See [Webster], America, N.Y. Daily Advertiser, Dec. 31, 1787, in 15 DocumentARY HiSTORY, supra note 1, at 199. 
sources of vagueness, but at the time they were drafted and ratified they apparently did not cause concern on this ground.285 The tenth amendment, which reserved to the people and the states powers not granted by the Constitution, grew out of Anti-Federalist demands for greater precision about the extent of federal power. The Articles of Confederation had reserved to the states all powers not given to Congress, and during ratification some Anti-Federalists complained about the failure of the Constitution to include such a provision. ${ }^{286}$ A clause reserving powers would, they thought, help to define and limit federal power. ${ }^{287}$

The ninth amendment arose from Federalist objections to a bill of rights, but like the tenth amendment it was perceived as a means of clarifying federal power. During ratification, some Federalists said a bill of rights was futile, since no one could foresee what invasions of rights would occur in the future and therefore a bill of rights could not be made permanent. ${ }^{288} \mathrm{~A}$ related and more common Federalist argu-

285. An explanation of why article IV's "privileges and immunities" language did not seem particularly vague is suggested infra at note 314 .

286. See, e.g., Lenoir in North Carolina Ratification Convention, July 30, 1788, in $4 \mathrm{~J}$. ELLIOT, supra note 1, at 206; Amendments to the Constitution, No. 1, North Carolina Ratification Convention, Aug. 1, 1788, in id. at 244; Letters from the Federal Farmer, in 2 H. STORING, supra note 1 , at 324 . Note, however, that the tenth amendment, unlike the Articles of Confederation, did not speak of "expressly" delegated powers.

287. One Anti-Federalist said, perhaps rhetorically, that such an amendment would have been a satisfactory substitute for a bill of rights. Spencer in North Carolina Ratification Convention, July 29, 1788, in $4 \mathrm{~J}$. Elliot, supra note 1 , at $152,163$.

288. Iredell said:

A bill of rights, as I conceive, would not only be incongruous, but dangerous. No man, let his ingenuity be what it will, could enumerate all the individual rights not relinquished by this Constitution. Suppose, therefore, an enumeration of a great many, but an omission of some, and that, long after all traces of our present disputes were at an end, any of the omitted rights should be invaded, and the invasion be complained of; what would be the plausible answer of the government to such a complaint? Would they not naturally say, "We live at a great distance from the time when this Constitution was established. We can judge of it much better by the ideas of it entertained at the time, than by any ideas of our own. The bill of rights, passed at that time, showed that the people did not think every power retained which was not given, else this bill of rights was not only useless, but absurd. But we are not at liberty to charge an absurdity upon our ancestors, who have given such strong proofs of their good sense, as well as their attachment to liberty. So long as the rights enumerated in the bill of rights remain unviolated, you have no reason to complain. This is not one of them." Thus a bill of rights might operate as a snare rather than a protection. If we had formed a general legislature, with undefined powers, a bill of rights would not only have been proper, but necessary; and it would have then operated as an exception to the legislative authority in such particulars. . . . But where they [i.e., powers of legislation] are powers of a particular nature, and expressly defined, as in the case of the Constitution before us, I think, for the reasons I have given, a bill of rights is not only unnecessary, but would be absurd and dangerous.

Iredell in North Carolina Ratification Convention, July 28, 1788, in id. at 149 . An anonymous Federalist wrote:

Suppose such a bill of rights formed, and the Constitution ratified and in exercise. An adventitious circumstance arises, for which no provision has been made in the Constitution, and is wholly left out of the bill of rights; from whence must the power flow to remedy or provide against the evil. By the Constitution there is no power vested in the government; by 
ment was that an enumeration of rights would be construed to disparage unenumerated rights and to imply unenumerated federal powers. ${ }^{289}$ Federalists insisted that the enumeration of federal powers provided a clear boundary between federal power and the people's rights and that an enumeration of rights would be used to imply the existence of congressional powers where rights were not mentioned. It was to counter these possibilities and, perhaps, to avoid charges of hypocrisy, ${ }^{290}$ that Madison proposed what became the ninth amendment. The ninth amendment was not on the whole perceived as vague, because the unenumerated rights to which it referred were defined by the enumeration of congressional powers. ${ }^{291}$ The unenumer-

the bill of rights, the people have lamented the sovereignty retained by them. I believe every man of common sense would say that the people, or the sovereign power, cannot be affected by any such declaration of rights, they being the source of all power in the government; whatever they have not given away still remains inherent in them.

Reply to George Mason's Objections to the Constitution, New Jersey Journal, Dec. 19, 1787, in 3 Documentary History, supra note 1, at 154. According to Pendleton, if a bill of rights were adopted, "in the progress of things, [we may] discover some great and Important [right], which we don't now think of[.]" Letter from Edmund Pendleton to R.H. Lee, June 14, 1788, in 2 Letters and Papers of Edmund Pendleton, at 533 (1967); see also Sherry, The Founders' Unwritten Constitution, 54 U. CHI. L. Rev. 1127, 1164 (1987) (quoting Pendleton).

One of these quotations, Pendleton's, is cited by Sherry as evidence of a belief in mutable rights. In fact, Pendleton's language does not appear to have such a meaning. The words "discover" and "think of" suggest that Pendleton assumed Americans had a great many rights and might fail to enumerate all that they might one day need to assert. Pendleton's argument and the others quoted here aimed to discourage adoption of a bill of rights and have nothing to do with the mutability of rights, enumerated or not.

As proof that "[t]he inherent rights of the people ... were not thought to be static," Sherry also quotes Wilson on the "progressive" development of natural law. See Sherry, supra, at 1164 (quoting 1 Works OF J. WILSON, supra note 52, at 126-27). In fact, when Wilson wrote this about natural law he was not referring to constitutional or other legal rights. Instead, as he made explicit, he was discussing general laws or rules of "morals" and "[o]ur progress in virtue." See 1 WORKS OF J. WILSON, supra note 52, at 127.

289. Madison said in the House of Representatives: "[I]t might follow, by implication, that those rights which were not singled out, were intended to be assigned into the hands of the General Government, and were consequently insecure." 2 B. SchWARTZ, BILL OF Rights, supra note 1, at 1031 (June 8, 1789); see also Maclaine in North Carolina Ratification Convention, July 28, 1788, in 4 J. Elliot, supra note 1, at 140-41; Gov. Johnston in North Carolina Ratification Convention, July 28, 1788, in id. at 142; Iredell in North Carolina Ratification Convention, July 28, 1788, in id. at 149; Reply to George Mason's Objections to the Constitution, New Jersey Journal, Dec. 19, 1787; in 3 DocumenTARY HistoRY, supra note 1, at 154.

290. During ratification, Madison and other Federalists had argued against a bill of rights by citing its dangers. Consequently, Madison would have appeared hypocritical if later he had advocated the Bill of Rights without also proposing remedies for the risks of which he had complained. Nevertheless, there is no reason to doubt Madison's sincerity in wanting a bill of rights. See Rumble, supra note 110, at 122, 133.

291. In the Virginia Assembly, Randolph argued that the word "retained" in what became the ninth amendment was too vague. See Letter from Hardin Burnley to James Madison, Nov. 28, 1789, in 12 Papers of JAMES Madison 456 (1979) (cited by L. LeVy, Original INTENT AND THE Framers' Constitution 281 (1988)). Instead of the ninth amendment, Randolph preferred language prohibiting Congress from extending its own power. Randolph's alternative version indicates that Randolph shared the traditional understanding of the amendment's purpose, even if he thought the language inadequate. Randolph's alternative language also reveals that Randolph did not think the ninth amendment vague in the sense that it was an independent 
ated rights consisted of the freedom left by the absence of federal authority. ${ }^{292}$

Thus, both Federalists and Anti-Federalists argued on the assumption that certainty and precision were desirable. Of course, many framers probably preferred a lack of clarity to a stalemate. Moreover, the framers and ratifiers may have agreed to the words but differed on the meaning. Nevertheless, they apparently thought constitutions, including the United States Constitution, should be as clear as possible. They did not desire vagueness, least of all as a means of allowing constitutional law to adapt to social changes.

\section{B. Principles}

A "principle" often denotes an underlying idea or justification typically one that is general or nondetailed. Conceivably, therefore, the framers and ratifiers thought the Constitution contained principles that were indeterminate and that would permit constitutional law to be mutable according to circumstances. In fact, when the framers and

source of undefined federal rights - the sense in which today it is frequently considered vague. For a different perspective on this, see L. LEVY, ORIGINAL INTENT AND THE Framers ConSTITUTION 281 (1988).

292. This is the traditional interpretation of the ninth amendment. For more on the ninth amendment, see Kay, supra note 265 , at 269-73. Kay writes: "There is no extrinsic evidence whatsoever that the enactors thought that the ninth amendment might provide for an ongoing ... redefinition of rights." $I d$. at 270 .

A recent article argues that the "founders" did not consider the Constitution the exclusive source of constitutional law and, in particular, that they did not think the Constitution the sole source of rights. See Sherry, supra note 288. In support of this position, Sherry asserts that in its debates on the first ten amendments, the "House simply did not see much need for particularized enumeration of even the most unquestioned rights, because such rights clearly existed whether or not they were enumerated." $I d$. at 1165 . An express enumeration of essential rights was, however, the very purpose of the Bill of Rights.

Sherry contrasts two views of the Constitution: Was it fundamental law because it was a declaration of natural law and right? Or was it fundamental law because it was the positive act of the people? Sherry argues that the framers in the summer of 1787 were in the process of inventing the latter point of view and consequently still retained the "older" perspective. Id. at 1146-55. As a result, according to Sherry, they thought natural law a source of constitutional law, independent of the Constitution. Sherry's argument is problematic for several reasons. First, it does not adequately acknowledge American assumptions about contractual limitations on government and the sovereignty of the people, particularly as apparent from pamphlets and articles c. 1765-1790 and the various constitutions of the decade prior to 1787. Second, the article mistakes the role of "natural law" in the eighteenth century. It fails to recognize the degree to which "natural law" was considered to be an explanation of morality - not legally enforceable except to the extent embodied in positive law - and it ignores the distinction drawn by various modern natural law treatises between "natural" law and "fundamental" law. Third, Sherry's article treats the notion of natural right as if it were thought largely incompatible with, and superior to, a positive conception of law. Americans believed that the establishment of government required individuals to give up part of their natural liberty - a sacrifice particularly appropriate when forming a government in which the people would be sovereign. Although "life, liberty, and the pursuit of happiness" might be inalienable, the surrender of a large part of one's natural liberty to government was designed precisely to preserve that liberty. See J. Gough, supra note 22; Berns, supra note 48 , at 58-66. 
ratifiers mentioned "principles" in connection with the Constitution, they frequently meant, not ideas in the Constitution, but ideas that underlay or justified it. ${ }^{293}$ Although they also discussed principles contained in the Constitution, they did not thereby indicate any interest in indeterminacy or flexible constitutional law. ${ }^{294}$

When the framers and ratifiers referred to principles in the Constitution, they sometimes meant objectives or ideas that were not stated in individual provisions or limitations but were, nevertheless, said to be in the Constitution. Such a principle, for example, was the idea that the federal government should regulate the things that concerned the union. ${ }^{295}$ In discussing this sort of principle, the framers and ratifiers did not suggest that principles would or should facilitate adaptation of constitutional law.

Frequently, the word "principles" was used to denote individual clauses or limitations contained in the Constitution. When framers and ratifiers referred to such "principles" and indicated that the principles were vague, they expressed distinct disapproval. More often, when they talked of "principles" in the sense of the document's language, they spoke without disapproval and even favorably of the principles and did not suggest that they were indeterminate. They did not indicate that such principles could or should permit flexibility in constitutional law.

For example, Anti-Federalists often referred to rights as "principles." Rights, it will be recalled, were to be precisely and expressly stated in order to preserve liberty and republican government, even after the social foundations of those objectives had decayed. Occasionally, Anti-Federalist discussions of constitutional limitations and rights were explicit about the relationship of such principles to social changes. James Monroe pointed out that "fundamental principles form a check, even when the spirit of the times hath changed, indeed

293. This use of the term is significant, for it indicates that the framers and ratifiers often thought of principles as general, theoretical justifications or objectives that were distinct from the Constitution. Note also that in their discussions of principles relating to the Constitution, framers and ratifiers often left unclear whether they were using "principles" to refer to language in the document or to principles that underlay the language.

294. Robert Palmer argues, on the basis of the structure of the Constitution, that the Bill of Rights was understood to contain nonprincipled restraints on power rather than principles the meaning of which would change with time. Palmer, Liberties as Constitutional Provisions, in LibERTY AND COMMUNity: CONSTITUTION AND Rights IN THE EARLY AMERICAN RePUbLIC 55 (1987). This article argues that the Constitution and the Bill of Rights were understood to contain or embody principles, but that such principles were not thought to be means of flexibility in constitutional law. Except with respect to Palmer's use of "principles" to mean ideas that are necessarily indeterminate, this article is not inconsistent with Palmer's conclusions.

295. See Ramsay, An Address to the Freemen of South Carolina on the Federal Constitution, in P. ForD, PAMPhLETS, supra note 1, at 374. 
they retard and controul it."296 Another Anti-Federalist argued: "[I]n laying down a political system it is safer to rely on principles than upon precedents [i.e., the practices of governments], because the former are fixed and immutable, while the latter vary with men, places, times and circumstances." 297 These references to principles did not suggest that principles in the Constitution should be means of flexibility in application or interpretation, let alone opportunities for adaptation to social change. Indeed, for Anti-Federalists who were referring to rights, principles would withstand and perhaps even delay the effects of change in American society.

\section{General Language}

Similarly, general language was not desired as a means of providing indeterminacy for an adaptable constitutional law. When used to connote vague words or broad powers in the Constitution, "general" language was a term of criticism. ${ }^{298}$ Thus, for example, an Anti-Federalist complained of a clause being "general" rather than "clear and unequivocal." 299

When used, however, to suggest an absence of details rather than broad powers or indeterminacy, "general" language was not criticized. The examples of, among other things, previous constitutional documents suggested that constitutions should be stated generally. ${ }^{300} \mathrm{Gen}$ eral language could also be necessary to prevent obsolescence. As Hamilton explained when objecting to a list of the objects of revenue, "it would be absurd to fix it in the Constitution, both because it would be too extensive and intricate, and because alteration of the circumstances must render a change of the division indispensable. Constitutions should consist only of general provisions: the reason is, that they must necessarily be permanent . . ." ${ }^{301}$ It was in the nature of constitutions to be general, to exclude references to particular matters or details. ${ }^{302}$

296. Monroe, Some Observations on the Constitution, in 5 H. STORING, supra note 1, at 292.

297. Essays by William Penn, in 3 id. at 175.

298. See, e.g., Essays of Brutus, in 2 id. at 367, 421; Letters from the Federal Farmer, in 2 id. at 235, 325; Symmes, Letter to Captain Peter Osgoode, Jr., 4 id. at 62; Monroe, Some Observations on the Constitution, in 5 id. at 291-92.

299. Bloodworth in North Carolina Ratification Convention, July 25, 1788, in 4 J. Elliot, supra note 1, at 68.

300. The most recent and prominent English example, the Bill of Rights of 1689, was particularly general.

301. Hamilton in New York Ratification Convention, June 28, 1788, in 2 J. ElLIOT, supra note 1 , at 364 .

302. See also text infra accompanying note 315 . Madison argued that if the Constitution had established the common law and had therefore attempted to distinguish those parts of the 
On occasion, principles and notions of generality converged. Both Federalists and Anti-Federalists talked of including within the Constitution certain "general principles" - sometimes apparently in an attempt to emphasize that they meant principles that did not prescribe particulars. They sometimes needed to convey this meaning when discussing constitutional principles that would accommodate different state laws and practices by setting general restrictions and leaving details for legislation. A Federalist writer said that it was necessary "to fix general principles, which were, in a certain degree, accommodated to all the states." ${ }^{303}$ Another Federalist explained that the principle of trial by jury was not extended to civil cases in order to accommodate the different practices or demands of the states:

The right of trial by jury most certainly is not taken away, neither is there anything in the Constitution that looks to that point; it is altogether left to the general government to dilate the subject as they please. It is in their power, by a law to be enacted for that purpose, to suit the temper and dispositions of the different states as they please. The Constitution could only establish general principles; the extending and enlarging them to particular cases will be the business of the future Congress. 304

The extension of the Constitution's principles was the task of Congress. ${ }^{305}$ Using a similar approach on behalf of the opposite position, an Anti-Federalist suggested - albeit without using the word "principles" - a general clause that would provide for civil juries without listing the detailed practices of the states:

[I]nstead of the clause of forty or fifty words relative to this subject, why not use the language that has always been used in this country, and say, "the people of the United States shall always be entitled to the trial by jury." This would shew the people still hold the right sacred, and enjoin it upon congress substantially to preserve the jury trial in all cases, according to the usage and custom of the country. ${ }^{306}$

common law that would not be adopted in America, then "they must have formed a digest of laws, instead of a Constitution." Letter from James Madison to George Washington, Oct. 18, 1787, in 3 M. FARRAND, supra note 1, at 130.

303. Unitas, Pennsylvania Mercury, Jan. 5, 1788, in 3 Documentary History, supra note 1, at 195 (first printed in Trenton Mercury, Jan. 1, 1788).

304. Reply to George Mason's Objections to the Constitution, New Jersey Journal, Dec. 15, 1787 , in $i d$. at 158.

305. Pelatiah Webster wrote: "These powers of controul by the federal head or authority, are defined in the new constitution, as minutely as may be, in their principle; and any detail of them which may become necessary, is committed to the wisdom of Congress." Webster, Reply to Brutus (Nov. 4, 1787), in P. FoRD, PAMPHLETS, supra note 1, at 121; see also Letter from Henry Knox, Sept. 1787 (referring to "great" principles), in 13 DocumenTARY HISTORY, supra note 1, at 279 .

306. Letters from the Federal Farmer, in 2 H. STORING, supra note 1, at 327. Mason said, "The jury cases cannot be specified. A general principle laid down on this and some other points would be sufficient." Convention Notes of James Madison, Sept. 12, 1787, in 2 M. FARRAND, supra note 1, at 587. Anti-Federalists also used other language to address the problem of differ- 
He generally conceded that "we can fix only general principles, and, of necessity, must trust something to the wisdom and integrity of the administration." 307 These were arguments about the need for limitations that governed only general and important aspects of a subject. Like other discussions of principles, the references to general principles suggest that the framers and ratifiers saw neither indeterminacy in such general limitations nor opportunities for flexibility. ${ }^{308}$

\section{The Compatibility of Precision with Principles and General Language}

The evidence examined here is curious, for it indicates that men who acknowledged and even insisted upon the need for precise constitutional language, especially with respect to rights, referred to historical, common law rights and other portions of the Constitution as "principles" and sometimes called for "general language." From some perspectives, this may appear incongruous.

One explanation is that the word "principle" was frequently and almost deliberately misapplied. In the late eighteenth century the term was pretentiously applied to all sorts of highly detailed rules including, as has been seen, historical common law rights. ${ }^{309}$ (It is for this reason that framers and ratifiers frequently felt obliged to speak of "general principles" when referring to what we can simply call "principles.") The misuse of the word "principle" was much facilitated by legal terms of art, which then, as now, compacted vast amounts of erudition into a succinct phrase or word. Thus, to some extent, the apparent inconsistency of the framers and ratifiers who expected clar-

ences between the rights contained in the states' constitutions: "Although various in form, they are certainly not contradictory in substance." Essays by a Farmer, in 5 H. STORING, supra note 1 , at 13 .

307. Of course, he went on to say: "But the question is, do we not trust too much[?]" Letters from the Federal Farmer, in 2 H. STORING, supra note 1, at 275; see also id. at 249, 321. For a similar but less explicit statement, see Letters of a Republican Federalist, in 4 id. at 164.

308. For other examples of the phrase, albeit not in reference to the Constitution's language, sze Letter from Edmund Randolph to David Shepherd, July 25, 1787, in M. FARRAND, supra note 1, at 182 (Supp. 1987); Dickinson, Notes for a Speech, (June 30, 1787), in id. at 135 (Supp. 1987). The Federal Farmer thought the Constitution should not leave rights to "general principles and logical inferences." Letters from the Federal Farmer, in 2 H. STORING, supra note 1, at 326. Apparently, he meant, not principles contained in the Constitution, but the principle of construction that what was not granted to the federal government was reserved to the people.

309. Rights were not the only such "principles." Pendleton thought the apportionment ratio a "principle unequivocably fixed in the Constitution." Pendleton in Virginia Ratification Convention, June 5, 1788, in $3 \mathrm{~J}$. Elliot, supra note 1, at 41 . When discussing qualifications of members of Congress, David Ramsay referred to the "principles . . laid down" in article I, section 5. 1 FirSt Federal Elections, supra note 1, at 175.

One ratifier proclaimed: "legislators have at length [i.e., at last] condescended to speak the language of philosophy ...." Ames in Massachusetts Ratification Convention, Feb. 4, 1788, in 2 J. Elliot, supra note 1, at 155. 
ity in principles was an illusion, since a detailed rule could parade under the denomination of a "principle." 310

A further explanation arises from the preexisting nature of American constitutional rights. Both the Constitution and the first eight amendments identified, for the most part, known, existing rights and therefore could refer to those rights in what might be considered general language. The rights included in those documents were frequently thought of as common law rights. Deviations between what was claimed and what was thought to be inherited were not yet substantial, and therefore, like the English Bill of Rights a century earlier, the American Bill of Rights was considered largely a declaration of what the people already possessed. ${ }^{311}$ Hence, the unusual opportunity for language both general and precise. ${ }^{312}$

The Bill of Rights could be especially general in its language, because, as Robert Palmer has observed, it did not have to redefine rights. Of course, it was understood to "define" both rights and federal power in the sense that it would establish with greater clarity the boundary between the two. ${ }^{313}$ Moreover, it was particular in the sense of listing particular rights. Its language, however, could be relatively general. Whereas the 1787 Constitution had to clarify or alter the existing understandings of some rights in order to settle the authority of the federal government, the Bill of Rights typically was expected to identify rights without modifying current understandings of them. ${ }^{314}$

310. The word "maxim" could also be misused in this way. See, e.g., Mason in Virginia Ratification Convention, June 18, 1788, in 3 J. EllioT, supra note 1, at 508.

311. The Federal Farmer wrote: "We do not by declarations change the nature of things, or create new truths, but we give existence, or at least establish in the minds of the people truths and principles which they might never otherwise have thought of, or soon forgot." Letters from the Federal Farmer, in 2 H. STORING, supra note 1, at 324. J.F. Mercer - a congressional candidate in Maryland - supported "those declaratory acts and amendments, which will effectually guard the great and fundamental rights of the people." 2 FirST FEDERAL Elections, supra note 1,160 (Dec. 20,1789). Note also that whenever a "right" is mentioned in the Bill of Rights, the words "the right" are used.

312. During the drafting of the Bill of Rights, Madison warned his colleagues in the House of Representatives of

the difficulties arising from discussing and proposing abstract propositions, of which the judgment may not be convinced. I venture to say, that if we confine ourselves to an enumeration of simple, acknowledged principles, the ratification will meet with but little difficulty. Amendments of a doubtful nature will have a tendency to prejudice the whole system ....

The House of Representatives Debates, Aug. 15, 1789, in B. SchWARTZ, BILl of Rights, supra note 1, at 1096; see also Notes for Speech in Congress, 12 PAPERS OF JAMES MAdison, 193 (circa June 8, 1789); Letter from William Eustis to Jonathon Jackson, Dec. 6, 1788, in 1 FiRST FEDERAL Elections, supra note 1, 588.

313. See, e.g., A Marylander, To the Inhabitants of Baltimore Town, Sept. 12, 1787, in 2 First Federal Elections, supra note 1, at 145.

314. Of course the nature and extent of even existing rights could be subject to a difference of opinion. Therefore, the first ten amendments occasionally had to delve into details, or sometimes - when a difference of opinion could not be resolved - the amendments had to remain general to avoid the disagreement (a possible example being "cruel and unusual punishment"). This 
For this purpose, relatively few words were needed.

These two explanations - the misapplication of the word "principle" and the luxury of being able to declare rights - suggest why framers and ratifiers could expect precision from "principles" and from "general language" about rights. They are, however, incomplete explanations, because some framers and ratifiers appear to have believed that principles and general language, whether or not concerning rights, could really be precise. Anti-Federalists who criticized the Constitution's language for its lack of simplicity and clarity thereby revealed their expectation that it could have had both attributes. Federalists had similar ideas. A document of the Committee of Detail began by declaring that "[i]n the draught of a fundamental constitution, two things deserve attention . . . ." The second of these concerned language:

2. To use simple and precise language, and general propositions, according to the example of the constitutions of the several states. ${ }^{315}$

Although to some ears the reference to simplicity and general propositions may seem inconsistent with the call for precision, to the drafters of this document, it clearly was not.

Simplicity and precision were associated with one another in several eighteenth-century intellectual contexts. ${ }^{316}$ One such context was

article, however, here simply attempts to show that it was possible for framers and ratifiers to perceive most of the language in the Bill of Rights as general and yet relatively determinate.

The structural reasons for including rights in the original Constitution are discussed by Palmer, supra note 294 , at 88 . The Constitution established the definition of several rights with considerable particularity in order to modify or clarify those rights and the corresponding federal power. This explains the language of the rights contained in the body of the Constitution. Unlike most of the first ten amendments, the rights mentioned in the 1787 text did not simply refer to existing rights. Instead, the 1787 Constitution redefined older rights. For example, the right to a jury in civil cases was, as has been seen, carefully excluded. See supra text accompanying notes 210-12. The right of habeas corpus was stated in a way that expressly granted the federal government the power of suspension, which had been so vigorously contested in seventeenthcentury England. The definition of treason restricted the definition of the offense and elevated to constitutional status some of the procedural rights contained in the 1696 Treason Trials Act. (Wilson commended the Constitution's definition of treason as "particular and accurate." Wilson in Pennsylvania Ratification Convention, Dec. 7, 1787, in 3 M. FARRAND, supra note 1, at 163.) These were all attempts to modify traditional understandings of rights and government power. For this, particularity was necessary.

In accord with this view of the relative particularity of the 1787 text as it related to rights, note that the "priviledges and immunities" clause simply restated a portion of article four of the Articles of Confederation. The Constitution did not have to modify that right and therefore could refer to it in the same brief or general language as the Articles of Confederation.

315. The version of this proposition reproduced above is the product of deletions in the manuscript. Prior to such alteration, the word "several" preceded the word "constitutions," and after the sentence quoted came the following: "For the construction of a constitution of necessarrily [sic] differs from that of law." 2 M. FARRAND, supra note 1, at 137. For the first of these "two things [that] deserve attention," see supra text accompanying note 129 . Incidentally, contemporaries appear to have wanted state constitutions, particularly their bills of rights, to be "precise" and "unambiguous." W. AdAMS, ThE First AMERICAN Constitutions 146 (1980).

316. On this subject, see Powell, supra note 7, at 888-902. 
the common law itself and the tradition of the ancient constitution. In the late fifteenth century, according to Hale, pleading had been "short yet perspicuous." 317 Well aware of Hale's example, many eighteenthcentury lawyers contrasted the clear and simple pleading of the older common law against the complexity of modern practice. Wilson waxed eloquent on the importance of certainty in "all good administration of law" and then added "that the common law is equally remarkable for the simplicity as for the accuracy of its forms." 318

In addition to this common law tradition, a variety of other influences encouraged a natural interest in accurate language that was easily comprehensible. ${ }^{319}$ Expectations of easily understood language were raised by Roman law, republican sentiments, some aspects of Protestantism, and a distaste for lawyers, who thrived on what baffled others. ${ }^{320}$ Anti-Federalists urged not only that the Constitution's language should have been more clear but also occasionally that it should have been more "plain," "simple," or "common." 321 In so doing, they apparently assumed that ordinary and simple language would promote clarity and ease of understanding, especially among the uneducated or unsophisticated. ${ }^{322}$

Even developments in the sciences may have stimulated Americans to associate precision with principles and simple or general language. ${ }^{323}$ Just as the rules governing the movements of the planets were discovered to be relatively simple and general, so too accurate descriptions of moral and now positive law could be expected to have such traits. Moreover, the attempt to make law mimic the moral and

317. M. HALE, supra note 28 , at 111 .

318. Lectures, in 2 Works OF J. WILSON, supra note 52, at 453.

319. Other factors may have included the continental experiments in preventing interpretation or commentaries.

320. Of course, these traditions could provoke varied responses. For example, Roman law could be associated with clear generalizations. It also could be feared for containing vague generalizations. See, e.g., W. Livingston, The InDEPENDENT REFlector 252-53 (M. Klein ed 1963) (June 7, 1753).

321. One Anti-Federalist wanted a bill of rights "in such general terms; so expressive, so clear, and at the same time so short, as never to require either comment or interpretations." Letter from a Delegate Who Has Catched Cold, in 5 H. STORING, supra note 1, at 273.

322. Some Anti-Federalists - but not clearly many of them - took this view to the extreme of insisting that a well-drafted constitution would need no interpretation. This extreme position is discussed by Powell, supra note 7. Note, however, that some of the Anti-Federalists who concluded that ordinary people would not understand the Constitution based such complaints on the ambiguity of the Constitution and the complexity of its structures rather than on the absence of plain or simple language. See, e.g., Letter from Samuel Osgood to Samuel Adams, Jan. 5, 1788, in 15 Documentary History, supra note 1, at 264; L. Martin, Address No. 3, Md. Journal, March 28, 1788, in $16 \mathrm{id}$. at 499.

323. For analysis of scientific approaches to law, see D. BooRSTiN, supra note 24, at 12-30; Hoeflich, supra note 22; Shapiro, supra note 24. 
natural sciences encouraged the common habit, discussed above, of asserting that common law and historical rights were "principles." 324 Pretentious language rarely can transform something into what it is not, but it can have consequences. In this instance, it contributed to the belief that principles could be as precise as Anglo-American historical rights. ${ }^{325}$ This and the other ideas mentioned here encouraged the framers and ratifiers to think that principles and simple or general language could be clear.

Although many complained that the generalities and principles in the proposed Constitution were vague, almost all of the framers and ratifiers argued on the assumption that principles and general language in a constitution could be relatively precise. They thought of constitutional law as permanent and did not want vagueness, principles, or general language to be opportunities for a flexible constitutional law that could change according to circumstances.

\section{CONCLUSION}

The framers and ratifiers did not want the Constitution to change in adaptation to the economic, political, cultural, or moral developments of American society. On the contrary, both Federalists and Anti-Federalists wanted a permanent constitution. Anti-Federalists typically clung to traditional notions of what was fundamental to liberty and republican government and sought to establish or fix those essentials on a permanent basis, notwithstanding and sometimes even in defense against the social changes they anticipated. Federalists did not generally disagree with the objective of establishing provisions fundamental to free government. However, they also strove for a constitution that would survive changes in American society and therefore attempted to exclude from the Constitution all that might become obsolete. Their fear of obsolescence affected their understanding of what was essential and led them to abandon many provisions their opponents would not. In so doing, Federalists hoped to establish permanently the relatively few elements of free government that, to their minds, belonged in a constitution. Anti-Federalists tended to accept the goal of a lasting, survivable constitution but not the cost, which was the sacrifice of provisions they considered essential to liberty and republican government. Thus, Federalists and Anti-Federalists agreed

324. See supra text accompanying notes 296-97, 303-08.

325. It also affected the perception and interpretation of constitutional rights, but that is another story. 
on the necessity of a permanent constitution; they differed about how to achieve it and about the provisions it should contain.

Just as constitutional law was assumed to be permanent, so too law that could not be permanent - that would have to be adapted to changing circumstances - could only be nonconstitutional law. This assumption underlay the Federalists' willingness to have relatively few constraints in the Constitution and to permit Congress broad discretion. It also underlay the difficulties encountered by Anti-Federalists when responding to Federalist arguments against impermanent provisions. Law that would have to be mutable could not be constitutional law.

Consistently with their views on the nature of the Constitution, the framers and ratifiers did not desire vagueness, principles, or general language to be sources of indeterminacy that would permit constitutional law to evolve or otherwise change in accord with the continuing development of American society. Although a number of them recognized that adaptation of constitutional law might be necessary, they assumed it should occur by amendment and preferred that the need for adaptation be avoided.

The late eighteenth-century ideas discussed in this article occurred during what could be considered a transitional phase in the development of Anglo-American conceptions of law. As suggested in Part I, the tradition that law and particularly constitutional law should remain largely unaltered has gradually been displaced by the expectation that law must change with the alterations of society. In the late eighteenth century, what would become the modern point of view was rapidly acquiring adherents, but the older approach was still widely appreciated. As a result, the framers and ratifiers had the opportunity to integrate this twofold intellectual inheritance. At least some of them perceived nonconstitutional law in accord with the modern, developmental perspective. Yet for constitutional law, almost all of them took approaches consistent with the older understanding, which emphasized the unchanging character of law. Constitutional law was permanent.

To the extent it lasted, this understanding of constitutional law as permanent was largely an American perspective. On the other side of the Atlantic, shortly after the framers and ratifiers created our Constitution, the great English defender of America, Edmund Burke, prepared his defense of England's unwritten constitution. Following the example of Hale, Burke thought the English constitution, like the common law of which it was a part, consisted of custom that slowly and insensibly adapted to changing circumstances. It developed with 
English society yet remained legitimate by virtue of its apparent antiquity. Through the writing of Burke, such a view eventually came to define English constitutional law; and that perspective could suit England - a relatively small, homogenous society in which tradition was still a source of authority and men and women were accustomed to defer to the elite arbiters of tradition. Americans, however, had recently asserted independence, they lived in a relatively diverse and egalitarian society, and they looked to themselves as the ultimate source of political authority. For them, a very different conception of constitutional law seemed appropriate. Constitutional law was permanent law. It did not change according to circumstances. 